Article (refereed) - postprint

Peñuelas, Josep; Sardans, Jordi; Llusia, Joan; Silva, Jorge; Owen, Susan M.; Bala-Ola, Bernadus; Linatoc, Alona C.; Dalimin, Mohamed N. ; Niinemets, Ulo. 2013. Foliar chemistry and standing folivory of early and latesuccessional species in a Bornean rainforest.

(C) 2013 Botanical Society of Scotland and Taylor \& Francis

This version available http://nora.nerc.ac.uk/500153/

NERC has developed NORA to enable users to access research outputs wholly or partially funded by NERC. Copyright and other rights for material on this site are retained by the rights owners. Users should read the terms and conditions of use of this material at http://nora.nerc.ac.uk/policies.html\#access

This is an Author's Accepted Manuscript of an article published in Plant Ecology \& Diversity (2013), 6(2). 245-256, copyright Botanical Society of Scotland and Taylor \& Francis, available online at: http://www.tandfonline.com/10.1080/17550874.2013.768713 


\section{Foliar chemistry and standing folivory of early and late successional species in a Bornean rainforest}

Josep Peñuelas $^{1,2 *}$, Jordi Sardans ${ }^{1,2}$, Joan Llusià ${ }^{1,2}$, Jorge Silva ${ }^{1,2}$, Susan M. Owen ${ }^{1,3}$, Bernadus Bala-Ola ${ }^{4}$, Alona C. Linatoc ${ }^{5}$, Mohamed N. Dalimin ${ }^{5}$, Ülo Niinemets ${ }^{6}$

${ }^{I}$ CSIC, Global Ecology Unit, CREAF-CEAB-UAB, Cerdanyola del Vallés 08913, Catalonia, Spain; ${ }^{2}$ CREAF, Cerdanyola del Valles 08193, Catalonia, Spain; ${ }^{3}$ Centre for Ecology and Hydrology, Edinburgh, Penicuik, EH26 0QB, Scotland, Great Britain;

${ }^{4}$ Royal Society SEARRP, Danum Valley Conservation Area, Sabah, Malaysia; ${ }^{5}$ Faculty of Science, Arts and Heritage, Universiti Tun Hussein Onn, Malaysia, 86400, Parit Raja, Batu Pahat, Johor, Malaysia; ${ }^{6}$ Institute of Agricultural and Environmental Sciences, Estonian University of Life Sciences, Kreutzwaldi 1, Tartu, 51014, Estonia

*Corresponding author. E-mail: josep.penuelas@ uab.cat

Running headline: Leaf traits and herbivory in a rainforest 


\section{ABSTRACT}

Background: Few studies have investigated the chemical, morphological and physiological foliar traits and the intensity of standing folivory in a representative set of species of tropical rainforests including species of different successional stages.

Aims : (i) To quantify leaf elemental composition, leaf phenolics and tannin concentrations, physical leaf traits and the intensity of standing folivory in a representative set of species of different successional stages in a Bornean tropical rainforest, and (ii) to investigate the relationships among leaf traits and between leaf traits and accumulated standing folivory.

Methods: Analyses of leaf elemental concentrations, phenolics (Ph) and tannin (Tan) concentrations, leaf mass area (LMA), C assimilation rate and accumulated standing folivory in 88 common rainforest species of Borneo.

Results and Conclusions: Accumulated standing folivory was correlated with the scores of the first axis of the elemental concentrations PCA (mainly loaded by K and $\mathrm{C}: \mathrm{K}$ and $\mathrm{N}: \mathrm{K}$ ratios) with lower accumulated standing folivory at high leaf $\mathrm{K}$ concentrations $(\mathrm{R}=-0.33, P=0.0016)$. The results show that consistent with growth rate hypothesis, fast-growing pioneer species have lower leaf $\mathrm{N}: \mathrm{P}$ ratios than late successional species, that species with higher leaf $\mathrm{N}$ concentration have lower LMA according with 'leaf economics spectrum' hypothesis, and that species with lower leaf nutrient concentration allocate more $\mathrm{C}$ to leaf phenolics. This study also shows that species with different ecological role have different biogeochemical 'niche' assessed as foliar elemental composition. 
Keywords: biogeochemical niche; ecological stoichiometry; foliar elemental concentration; growth rate hypothesis; herbivory; LMA; N:P; phenolics; rainforest; tannins; successional stages; trace elements.

\section{Introduction}

The 'biogeochemical niche' hypothesis proposes that plants competing in the same community tend to use the nutrients in different amount and proportion, which should diminish the competition for resources among them (Peñuelas et al. 2008; Peñuelas, Sardans, Llusia, Owen, Carnicer et al. 2010). This has been observed when comparing leaf elemental composition in plants growing in different climatic conditions (Peñuelas et al. 2008) and when comparing native and coexisting alien species (Peñuelas, Sardans, Llusia, Owen, Carnicer et al. 2010). Thus, the 'biogeocheminal niche' hypothesis, by considering organisms' elemental chemical composition, provides a new tool to study the suitability of niche partitioning among coexisting species. This implies the use of elements in different proportions and consequently different plant elemental composition among different species (Peñuelas et al. 2008; Peñuelas Sardans, Llusia, Owen, Carnicer et al. 2010). Element concentrations and their ratios constitute the final phenotypical expression of the different biogeochemical niches. Different biological functioning results in different proportional contents of different molecules and structures built from different proportions of elements such as carbon $(\mathrm{C})$, nitrogen $(\mathrm{N})$, phosphorus (P) or sulphur (S). Moreover, several physiological mechanisms such as those involved in water conservation strategies are directly related to some elements, such as $\mathrm{K}$ or Ca. Competitive exclusion is determined by nutrient availability and by the degree of different nutrient requirements of species, such as observed in aquatic (Tilman 
1986; Tilman and Wedin 1991) and terrestrial (Mamolos et al. 1995; Gusewell and Bollens 2003; Everard et al. 2010; Venterink and Gusewell 2010; Harpole and Suding 2011) ecosystems.

Tropical forest tree diversity has been observed to be correlated with soil nutrient contents in many studies (Laurance et al. 2010; Long et al. 2012; Sahu et al. 2012) and soil nutrient distribution has been correlated with tree species distribution (John 2007). Thus the differences in leaf nutrient concentrations and stoichiometry of species should reflect and be correlated with species diversity in rainforests. Competition among species can diminish when they take up different elements in different proportion and/or take advantage of micro-scale soil differences. In addition, plant species of different successional stages can have different nutrient requirements and consequently different foliar elemental composition. An and Shangguan (2010) have observed different foliar elemental stoichiometry in different successional communities on the Loess Plateau of China.

These differences in the foliar elemental concentrations can influence herbivore behaviour and anti-herbivore defence strategies (Kusar and Coley 1991; Crone and Jones 1999; Mundin et al. 2009). Different foliar elemental composition can be directly related to leaf palatability, for example leaves that have higher nutrient concentrations and lower $\mathbf{C}$ to nutrients ratio can be more palatable and experience extensive folivory (Yamasaki and Kikuzawa 2003; Kurokawa and Nakashizuka 2008). Leaf elemental concentration can also affect leaf palatability indirectly, e.g. the synthesis of secondary metabolites linked to anti-herbivory defence can be related to leaf nutrient concentrations and stoichiometry and especially with $\mathrm{N}$ concentration since phenolics and protein synthesis compete for their main common synthesis precursors, phenylalanine (Jones and Hartley 1999; Peñuelas and Estiarte 1998). Given the variety 
of plant defences against herbivores and that their effectiveness appears to depend on the environment and the composition of the herbivore community, it is plausible that plant defence traits lie along a spectrum of niche axes that can foster the coexistence of many species. It is optimal for each herbivore to consume leaves with the most similar stoichiometry to itself to optimize its metabolic efficiency.

Although various kinds of plant defences are known to be effective against herbivory, less is known about which defence strategies are most effective in specific environments and especially regarding those linked directly or indirectly to leaf elemental composition and different molecular composition. Under low nutrient availability, plant species have also relatively higher leaf mass area (LMA) and leaf morphological traits that are associated with C-rich structural compounds, and these altogether can act as deterrent to herbivores (Kursar and Coley 2003). Plants that have low $\mathrm{C}$ to nutrient ratios, high photosynthetic capacity, and low LMA will invest relatively less in chemical defences (Bryant et al. 1983; Herms and Mattson 1992; Kursar and Coley 2003; Eichhorn et a1. 2007). Several studies have suggested that investment in physical leaf defences, such as high LMA, which is associated with the allocation of $\mathrm{C}$ to $\mathrm{C}$-structural molecules, e.g., lignin or cellulose, might compete with the demands for inyestment in phenolics and tannins (Fincher et al. 2008). In this context, ‘leaf economics spectrum' (LES) predicts an inverse relationship between leaf production capacity (nutrient content and photosynthetic rates) and the investment in leaf structure (Wright et al. 2004). Moreover, phenolic synthesis can compete with protein synthesis for $\mathrm{N}$ and $\mathrm{P}$ sources (Jones and Hartley 1999). Phenolics and tannins are secondary metabolites that act as defensive compounds (Reed 1995). Phenolics are present in high concentrations in leaf tissues (typically between $5-40 \%$ dry weight) (Meyer and Karasov 1989; Adams et al. 2009; Peñuelas, Sardans, Llusia, Owen, Silva 
et al. 2010). They are effective against a broad range of herbivores (Coley et al. 1985; Kouki and Manetas 2002; Novotny et al. 2002). The effect of phenolics depends on their tissue concentrations (Feeny 1992; Nomura and Itioka 2002) since they act by reducing digestibility to herbivores, rather than directly through toxicity (Eichhorn et al. 2007).

Few studies have investigated the intensity of accumulated standing foliyory in relation to the leaf nutrient concentrations and stoichiometry, and the leaf chemical defenses in a representative set of species of tropical rainforests (Wu et al. 2007). Such studies are especially uncommon in the rainforests of Asia (Wu et al. 2007). A few studies have investigated specific defensive leaf compounds such as tannins (Eck et al. 2001; Kurokawa et al. 2004), LMA (Turner et al. 2000), and leaf morphological properties such as toughness (Fincher et al. 2008), in the most common tree species in the Bornean rainforest. These studies have observed considerable levels of tannin contents in some dominant tree species (Kurokawa et al. 2004), some relationships between leaf tannin concentrations and protection against herbivory in species of the genus Macaranga (Eck et al. 2001) and a relationships between LMA and leaf N concentration (Turner et al. 2000) and apparently no relationships between leaf toughness and herbivore attack (Fincher et al. 2008). Kurokawa and Nakashizuka (2008) examined the relationships between some leaf traits and herbivory rates in 40 woody species in the rainforest of the Malacca Peninsula and found that some leaf traits such as $\mathrm{N}$ concentration, $\mathrm{C}: \mathrm{N}$ ratio, and leaf physical traits accounted for a small amount of the variance in accumulated standing folivory when phylogenetic relationships were included in the analyses. Collectively, those studies indicated that many defensive mechanisms beyond $\mathrm{C}: \mathrm{N}$ ratios and specific leaf morphologies are used by woody species in tropical Asian rainforests. As far as we know, no study has investigated the 
relationships among nutrient and trace element concentrations and stoichiometry, leaf phenolic and tannin concentrations, and accumulated standing folivory in a large number of the most common woody species in a primary rainforest in Borneo including species of different succesional stages.

In Borneo, many soils are N- and P-limited (Nomura and Kikuzawa 2003; Paoli et al. 2005; Paoli 2006); e.g., typically, soil $\left(\mathrm{NH}_{4} \mathrm{OAc} / \mathrm{HOAc}\right)$-extractable concentrations are $<1 \mu \mathrm{g} \mathrm{P} \mathrm{g}^{-1}$ (Brearley et al. 2007). In nutrient-limited tropical ecosystems, plant defences against leaf herbivores can be adaptations to avoid the loss of nutrients. Borneo rainforests have high tree diversity (Wills et al. 2006), which makes them adequate to study the effects of environmental and phylogenetic factors on plant traits. In addition, insect diversity is very high in Borneo (Stork 1991; Dial et al. 2006) and highly diverse plant-insect interactions are assumed to exist there.

We hypothesised that in this highly diverse tropical forest the different use of nutrients as final expression of different defensive, successional and nutrient-use strategies should be related to different foliar elemental concentrations and stoichiometry among the different species. We thus linked elemental stoichiometry, including N:P ratios, with leaf traits related to production capacity, such as LMA, leaf N concentration and photosynthetic rates.

We analysed 88 woody species occupying various stages of ecological succession in the rainforest in the Danum Valley, Sabah, Malaysia with the following aims: (i) to quantify their foliar chemical traits, (ii) to investigate the relationships among their leaf elemental concentrations and stoichiometries, leaf phenolic and tannin concentrations, LMA, and the accumulated standing folivory.

\section{Methods}




\section{Study site}

The study site was within the $438-\mathrm{km}^{2}$ Danum Valley Conservation Area (a Class I protected rainforest $)\left(117^{\circ} 48.75^{\prime} \mathrm{E}, 5^{\circ} 01^{\prime} \mathrm{N}\right)$, Borneo Island. The field station is on the periphery of the conservation area, which is within the Ulu Segama Forest Reserve, a portion of the $\sim 10,000-\mathrm{km}^{2}$ Yayasan Sabah Forestry Concession. The Danum Valley conservation area is the largest parcel of undisturbed lowland dipterocarp forest in Sabah. Dipterocarp trees predominate in the forest within the field station and, in spots, the canopy is $>70 \mathrm{~m}$ high. Ninety percent of the area is lowland dipterocarp forest and $10 \%$ is low-canopy, sub-montane forest, mostly at Mt. Danum, in the centre of the Conservation Area. The climate is equatorial and the mean annual temperature is 26.8 ${ }^{\circ} \mathrm{C}$. Temperatures $>34{ }^{\circ} \mathrm{C}$ are rare and occur during prolonged dry periods, only. Minimum temperatures below $19^{\circ} \mathrm{C}$ are rare. Mean relative humidity at 08:00 $\mathrm{h}$ and $14: 00 \mathrm{~h}$ are $95 \%$ and $78 \%$, respectively. Mean annual rainfall (1985-2006) is $2,825 \mathrm{~mm}$. Typically, rainfall is lowest in March and April, which are the most drought-prone months during ENSO events, and in August and September, when the south-westerly monsoon is at its height.

\section{Plant species}

Eighty-eight common woody species were studied (Figure 1). Species nomenclature

followed the local floras (Whitmore 1972; Soepadmo et al. 2004). The successional position (early-, mid-, late-), life form, and heights (Table S1 Supporting information) of species were based on Cockburn $(1976,1980)$ and Köhler et al. (2000). The study included 19 early-, 44 mid-, and 25 late-successional species.

\section{Plant sampling}


Plant sampling was conducted in medium and large forest gaps (10-100 m diameter). Well-developed, mature but non-senescent, sun-oriented leaves located at the tips of branches (between 2 and $10 \mathrm{~m}$ height) were collected from at least three randomly selected mature trees of each species, at least 100 m apart. Generally at least 20 leaves (average $\pm \mathrm{SE}=20.2 \pm 0.7$ leaves, $\mathrm{n}=264$ plants) were collected from each plant, although fewer leaves were collected from large-leafed species that have a small number of large leaves; e.g., Artocarpus anisophyllus, Helicia artocarpoides, and Macaranga gigantea. In parallel, twigs for gas-exchange measurements were collected between 08:00 $\mathrm{h}$ and 12:00 $\mathrm{h}$. After the twigs were cut under water, they were placed in water in plastic bags, which stopped transpiration while the samples were transported to the laboratory. In the lab, the twigs were cut again under water and allowed to stabilise at room temperature $\left(25-28^{\circ} \mathrm{C}\right)$ in dim light. To maximise stomatal openness and obtain stable maximum values of photosynthetic capacity $\left(A_{\text {mass }}\right)$, measurements were made the following day (Niinemets et al. 2005; Niinemets et al. 2009).

\section{Leaf physiological and morphological analyses}

The photosynthetic capacity $\left(A_{\text {mass }}\right)$ of the leaves $\left(\mu \mathrm{mol} \mathrm{g}^{-1} \mathrm{~s}^{-1}\right)$ was measured using an ADC pro (LCpro+ Portable Photosynthesis System, ADC BioScientific Ltd. Hoddesdon, Herts) gas exchange system at a quantum flux density of $1000 \mu \mathrm{mol} \mathrm{m}^{-2} \mathrm{~s}^{-1}$, a leaf temperature of $25^{\circ} \mathrm{C}$, and an ambient $\mathrm{CO}_{2}$ concentration of $385 \mu \mathrm{mol} \mathrm{mol}^{-1}$.

The leaves collected for the folivory analyses were sealed in plastic bags that contained wet filter paper and immediately transported to the laboratory at the field station. In the laboratory, the fresh mass of each leaf was determined and, to calculate leaf area and accumulated standing folivory, they were pressed flat between a white board and a large transparent acrylic sheet before being photographed (following 
Niinemets et al. 2003). The digital photographs were taken using a Nikon Coolpix 990 camera (Nikon Corporation, Tokyo, Japan) from a distance (1.4-2.0 m) that depended on the size of the leaf.

After the dimensions and the standing folivory of the leaves were measured, they were dried in an oven at $70{ }^{\circ} \mathrm{C}$ for at least $48 \mathrm{~h}$ before the dry mass of each leaf was determined. Those measurements were used to calculate the leaf dry mass per unit area (LMA, $\mathrm{g} \mathrm{m}^{-2}$ ) and the leaf dry mass to fresh mass ratio. Eight of the species examined had compound leaves (Caesalpina major, Cassia alata, Clausena excavata, Duabanga moluccana, Fordia splendidissima, Leea indica, Reinwardtiodendron humile and Sindora irpicina) and, in those species, leaflets were considered functional analogues of simple leaves and all structural and chemical traits refer to leaflets.

\section{Leaf chemical analyses}

Dried leaves were ground in a CYCLOTEC 1093 sample homogeniser (Foss Tecator, Höganäs, Sweden). To measure the concentrations of C and N, 1-2 mg of the pulverised dried sample was mixed with $2 \mathrm{mg}$ of $\mathrm{V}_{2} \mathrm{O}_{5}$ (an oxidant). $\mathrm{C}$ and $\mathrm{N}$ concentrations were determined by combustion coupled to gas chromatography using a Thermo Electron Gas Chromatograph model NA 2100 (C.E. instruments-Thermo Electron, Milan, Italy). For the determination of other elements, dried ground samples were digested, using concentrated $\mathrm{HNO}_{3}$ and $\mathrm{H}_{2} \mathrm{O}_{2}(30 \%, \mathrm{p} / \mathrm{v})$ in a microwave oven. To assess the accuracy of the digestions and the analytical procedures, a certified standard (NIST 1573a, tomato leaf, NIST, Gaitherburg, MD) was used as a reference. The concentrations of As, $\mathrm{Cd}, \mathrm{Cr}, \mathrm{Cu}, \mathrm{Mo}, \mathrm{Ni}, \mathrm{Pb}, \mathrm{V}$, and $\mathrm{Zn}$ were determined using Inductively Coupled Plasma Mass Spectrometry, and the concentrations of $\mathrm{Ca}, \mathrm{Fe}, \mathrm{K}, \mathrm{Mg}, \mathrm{Mn}, \mathrm{Na}$, and $\mathrm{P}$ were measured using Inductively Coupled Plasma Optic Emission Spectrometry. For As 
determination we used the hydride generation method. Briefly, As (V) was reduced to As (III) using a mixture of $\mathrm{HCl}(30 \% \mathrm{v} / \mathrm{w}), \mathrm{KI}(1 \% \mathrm{w} / \mathrm{v})$, and ascorbic acid $(0.2 \% \mathrm{w} / \mathrm{v})$ added to a digestion solution. The solution was pumped into a gas-liquid separator, where it reacted with $\mathrm{NaBH}_{4}(1.3 \% \mathrm{w} / \mathrm{v}$ solution in $0.1 \mathrm{M} \mathrm{NaOH})$ to form arsenic hydrides, which were analyzed using ICP-MS.

The phenolics $(\mathrm{Ph})$ concentrations of leaves were measured by using an improved Folin-Ciocalteu Assay (Singleton and Rossi 1965; Marigo 1973) which used a blank of polyvinylpolypyrrolidone (PVPP). An Helios Alpha spectrophotometer (Thermo Spectronic, Cambridge, UK) was used to the determination the absorbances of the samples A and B (at $760 \mathrm{~nm}$ ), with gallic acid as the standard for calibration.

Total soluble tannins (Tan) were extracted from $20 \mathrm{mg}$ of leaf powder with 12 $\mathrm{ml}$ of $70 \%$ acetone. After centrifugation, the extract was assayed with the butanol/ $\mathrm{HCl}$ method (Porter et al. 1986), modified as in (Makkar and Goodchild 1996). The absorbance was measured at $550 \mathrm{~nm}$ by spectrophotometer Helios Alpha (Thermo Spectronic, Cambridge, UK). Non-heated replicate tubes for each extract were used as anthocyanin blank and their absorbance values subtracted from the absorbance of the heated tubes (Porter et al. 1986). The Tta content on a dry weight basis was estimated by using a 1-cm-wide cuyette (Porter et al. 1986, Makkar and Goodchild 1996). Tan analyses were conducted in triplicate. For additional details on the analytical procedures, see Peñuelas, Sardans, Llusia, Owen, Carnicer et al. (2010).

\section{Determination of accumulated standing leaf folivory}

To quantify the extent of the damage caused to leaves by herbivores (we discarded other types of damage, such as necrosis from pathogens/fungi/bacteria), the digital images were processed to fill in all of the portions of each leaf that were removed by 
herbivores, and the area of each of the leaves were measured again by using the UTHSCSA Imagetool software to give a leaf area estimate, $S_{\mathrm{A}, \mathrm{T}}$. The proportion of each leaf that had been removed by herbivores, $F_{\mathrm{R}}$, was calculated as follows:

$$
F_{\mathrm{R}}=1-\frac{S_{\mathrm{A}}}{S_{\mathrm{A}, \mathrm{T}}}
$$

where $S_{\mathrm{A}}$ is the measured leaf area. Three indices were used to quantify the extent of the damage caused by herbivores. The average $F_{\mathrm{R}}$ of all of the leaves collected characterises the total accumulated standing herbivory damage (folivory). The coefficient of variation (standard deviation per sample mean) of $F_{\mathrm{R}}$ characterises the variation in the extent of accumulated standing folivory. The average of the three highest estimates of $F_{\mathrm{R}}$ provided an estimate of the potential vulnerability of a species to folivory.

\section{Statistical analyses}

All the leaf elemental concentrations and nutrient ratios were subjected to PCA and discriminant analyses. Thereafter, we correlated the scores of the species on Axis 1 of the PCA that represented their 'biogeochemical niche' (Peñuelas et al. 2008; Peñuelas, Sardans, Llusia, Owen, Carnicer et al. 2010) and the accumulated standing folivory of each species. Those analyses were performed using Statview 5.0.1 (SAS Institute Inc., Cary, NC, USA) and Statistica 6.0 (StatSoft, Inc. Tule, Oklahoma, USA).

Species-specific averages were calculated for leaf structure, foliage concentrations of elements, phenolics, and tannins, and accumulated standing folivory. The program Phylomatic (Webb and Donoghue 2005) was used to create a phylogenetic tree that included the 88 woody species (Figure S1; for details, see Peñuelas, Sardans, Llusia, Owen, Carnicer et al. (2010), Peñuelas et al. (2011) and section of Methods in the Supporting Information accompanying file). We correlated leaf nutrient 
concentrations and ratios with leaf LMA and $A_{\text {mass, }}$, the concentrations of phenolics and tannins, and accumulated standing folivory by using standardised major-axis regression. We also tested the possible effects of different successional stages on the leaf variables and on the accumulated standing folivory. When assessing multiple correlations, false discovery rate corrections were included in the analyses. Moreover, when simple regressions had a triangular form, a variance covariate was included in the model to take into account the side-effect.

\section{Results}

The different leaf concentrations of the 20 elements analysed, concentrations of phenolics and tannins, and the values of $\mathrm{A}_{\text {mass }}$ and of the morphological traits are shown in Tables S2, S3 and S4 (supporting information).

Differences in foliar elemental composition and accumulated standing folivory among species of different successional stages

The PCA conducted with the leaf concentrations of the 20 elements analysed, and the $\mathrm{C}: \mathrm{N}, \mathrm{C}: \mathrm{P}, \mathrm{C}: \mathrm{K}, \mathrm{N}: \mathrm{P}, \mathrm{N}: \mathrm{K}$, and $\mathrm{P}: \mathrm{K}$ ratios resulted in a $\mathrm{PC} 1$ explaining $17.7 \%$ of the total variance and significantly correlated with the extent of accumulated standing folivory $(\mathrm{R}=-0.24, P=0.025, \mathrm{n}=88$ ) (Figure 2). The PC2 (explaining $14.2 \%$ of the total variance) was significantly correlated with the leaf phenolics concentration $(\mathrm{R}=0.28, P$ $=0.006, \mathrm{n}=88$ ). PC2 scores separated species of different successional stages (Figure 2).

The extent of accumulated standing folivory was inversely correlated with leaf $\mathrm{K}$ content per leaf area unit, $\mathrm{K}_{\text {area }}(\mathrm{R}=-0.33, P=0.0016, \mathrm{n}=88 ; \mathrm{R}=0.27$ for $\mathrm{K}$ concentration, $P<0.05$ ) (Figure 3). The maximum amount of accumulated standing 
folivory (the proportion of a leaf consumed among the $10 \%$ most consumed leaves) and the coefficient of variation $(\mathrm{CV})$ of the proportion of the leaf consumed were also negatively correlated with $\mathrm{K}_{\text {area }}(\mathrm{R}=-0.25, P=0.02, \mathrm{n}=88$ and $\mathrm{R}=-0.29, P=0.006, \mathrm{n}$ $=88$ respectively). The extent of accumulated standing folivory was not significantly correlated with any of the other variables analysed (Table S5 and S6, supporting information).

Early successional species had higher leaf $\mathrm{P}$ concentrations and lower $\mathrm{N}: \mathrm{P}$ ratios (Figure 4). Among leaf morphological traits, leaves were more elongated in late successional species than in the early successional species $(\mathrm{F}=4.0, \mathrm{P}=0.021, \mathrm{n}=88)$. No significant differences among successional stages were observed in other foliar traits, including accumulated standing folivory (Table S6 and S7, supporting information). Leaf N:P ratio was not correlated with accumulated standing folivory (Table S5, supporting information).

Leaf $\mathrm{N}$ concentrations scaled at approximately $1 / 3 \quad(0.31)$ of leaf $\mathrm{P}$ concentrations $\left(\mathrm{N}=4.04 \mathrm{P}^{0.31}, P<0.001\right)$, and nitrogen concentration per leaf area $\mathrm{N}_{\text {area }}$ scaled at approximately $2 / 3(0.62)$ of $\mathrm{P}$ concentrations per leaf area $\mathrm{P}_{\text {area }}\left(\mathrm{N}_{\text {area }}=\right.$ $\left.7.46 \mathrm{P}_{\text {area }}{ }^{0.62}, \mathrm{P}<0.001\right)$.

\section{Elemental, phenolic and tannin concentrations, $A_{\text {mass }}$ and LMA relationships}

All the leaf nutrient concentrations per mass tended to be positively correlated with each other, but no strong correlations existed between the concentrations of nutrients and trace elements, or among the trace elements (data not shown). $\mathrm{N}, \mathrm{P}$, and $\mathrm{K}$ concentrations per leaf area were positively correlated with each other: $\mathrm{N}$ and $\mathrm{P}(\mathrm{R}=$ $0.8, P<0.001, \mathrm{n}=88), \mathrm{N}$ and $\mathrm{K}(\mathrm{R}=0.66, P<0.001, \mathrm{n}=88)$, and $\mathrm{P}$ and $\mathrm{K}(\mathrm{R}=0.8, P$ $<0.001, \mathrm{n}=88)$. 
Leaf $\mathrm{N}$ concentrations were positively correlated with $\mathrm{A}_{\text {mass }}(\mathrm{R}=0.41, P=$ $0.014, \mathrm{n}=35)$ and negatively with LMA $(\mathrm{R}=-0.33, P=0.001, \mathrm{n}=88)$ (Figure 5) and also with total leaf phenolics $(\mathrm{TPh})(\mathrm{R}=-0.24, P=0.027, \mathrm{n}=88)$ (Figure 6).

The extent of accumulated standing folivory was not correlated with leaf $\mathrm{Ph}$ or Tan (Table S6, supporting information). Discriminant analyses that included leaf compactness and leaf $\mathrm{K}_{\text {area }}(\mathrm{F}=5.17, P=0.0076, \mathrm{n}=88)$ discriminated between species that had low or high accumulated standing folivory.

Leaf $\mathrm{N}$ concentrations were negatively correlated with Tan $(\mathrm{R}=-0.34, P<$ $0.001, \mathrm{n}=88$ ) (Figure 5). Leaf $\mathrm{C}: \mathrm{N}$ ratios were positively correlated with $\mathrm{Ph}(\mathrm{R}=0.27$, $P<0.01, \mathrm{n}=88)$ and Tan $(\mathrm{R}=0.35, P<0.001, \mathrm{n}=88)$. Ph was positively correlated with LMA $(\mathrm{R}=0.23, P=0.032, \mathrm{n}=88)$ and with leaf dry:fresh weight (Table S7, supporting information); i.e. $\mathrm{Ph}$ were highest in the leaves that had the lowest water content $(\mathrm{R}=0.30, P=0.005, \mathrm{n}=88)$.

\section{Discussion}

Main findings

In addition to providing a survey of the foliar elemental composition and stoichiometry of a large set of tropical tree species (see supporting information), this study identified significant relationships of leaf elemental concentrations and stoichiometry with ecological variables such as the extent of standing accumulated folivory or the successional stage.

The scores of the PC1 of elemental concentrations, that was mainly loaded by leaf $\mathrm{K}$ concentrations and $\mathrm{P}: \mathrm{K}$ ratios, were negatively correlated with accumulated standing folivory, highlighting the role of $\mathrm{K}$ in plant-herbivore relationships, in agreement with some previous studies (Baskaran et al. 1985; Dale 1988). These results 
indicate that there is a relationship between the extent of folivory experienced by a species and its 'biogeochemical niche’ (Peñuelas et al. 2008; Peñuelas, Sardans, Llusia, Owen, Carnicer et al. 2010).

Early successional species, mostly fast-growing species, had higher leaf $\mathrm{P}$ concentrations and lower leaf N:P ratios than did mid- and late- successional species, which is consistent with the 'growth rate hypothesis' (Elser et al. 2000). Foliar N concentrations were positively correlated with $\mathrm{A}_{\text {mass }}$ and negatively correlated with LMA, which is consistent with the leaf 'economic spectrum paradigm" (Wright et al. 2004; Peñuelas, Sardans, Llusia, Owen, Carnicer et al. 2010). Thus, the results are consistent with the ecological stoichiometry paradigms showing that the high diversity of this ecosystem is related to the different elemental composition of the different species and that this elemental composition is related to different ecological properties. The results suggest that a differentiation in the use of nutrients can be underlying niche fragmentation and the coexistence of species of different successional stages. Different use of nutrients should diminish the competition intensity among different species. Moreover, leaves that had the lowest nutrient concentrations (low production capacity) allocated more $\mathrm{C}$ to the production of carbon-based secondary compounds such as phenolics and tannins. However, leaves with relatively high concentrations of phenolics and tannins, and high LMA did not present reduced accumulated standing folivory. Nevertheless, these results on folivory should be taken with caution because leaves with higher $\mathrm{C}$ to nutrient ratios live longer and may thus accumulate more leaf damage, leaves completely eaten are missed, and sun leaves do not represent the overall leaf biomass. Other mechanisms than those based on chemicals could be underlying plant defense in this ecosystem such as the susceptibility of herbivores to predator and parasitoid attack (Havill and Raffa 2000; Heil et al. 2001). All in all, the observed range 
of accumulated standing folivory, $0.09-21 \%$, is slightly under the range observed in previous studies in sets of tropical plant species in Australia, 3.3-41\% (Lowman 1992) and in south China, 3-16\% (Schuldt et al. 2010).

\section{Foliar elemental concentrations, successional stage and folivory}

Significant differences in the leaf concentrations of the 20 different elements and the stoichiometry of the most important ones $(\mathrm{C}, \mathrm{N}, \mathrm{P}, \mathrm{K})$, which represented the 'biogeochemical niche' (Peñuelas et al. 2008; Peñuelas, Sardans, Llusia, Owen, Carnicer et al. 2010) were found in species of different successional stage. Changes in plant N:P ratio (An and Shangguan 2010) and in plant nutrient use strategies (Yan et al. 2006) have been observed in some previous studies, but this is the first time, as far as we know, that a shift in the concentration of a set of 20 elements has been observed in the leaves of species of different successional stage of the same community. Species of early successional stages frequently have higher growth rates (Llambi et al. 2003), that should suppose a different use of nutrients and consequently different elemental and stoichiometric composition.

Other studies have described strong relationships between leaf elemental composition and the types of soil (Duvigneaud and Denaeyer-DeSmet 1968), but our study reports the relationships between element concentrations and stoichiometry in coexisting plant species and trophic relationships. In the highly diverse tropical forest ecosystem studied, different nutrient requirements composition among the different species could reduce competition among them and favour species niche differentiation. Taking into account that nutrients are frequently limiting in tropical rainforests (Tanner et al. 1998; Reich and Oleksyn 2004; Wright et al. 2011; Baribault et al. 2012; Santiago et al. 2012) this could be a factor that partly accounts for the great tree diversity 
observed in tropical rainforests (Paoli et al. 2006; Siddique et al. 2010; Long et al. 2012). In fact, soil heterogeneity affects early succession of plant communities (Collins and Wein 1998) and soil niche partitioning has been suggested by Paoli et al. (2006) in a study conducted in a Bornean rain forest.

Accumulated standing folivory was negatively correlated with leaf $\mathrm{K}$ concentrations and contents and positively correlated with leaf $\mathrm{C}: \mathrm{K}$ and $\mathrm{N}: \mathrm{K}$ ratios. These results are in accordance with previous ones also reporting negative correlations between leaf K concentrations and herbivore attack (Baskaran et al. 1985; Dale 1988). The negative effect of high leaf $\mathrm{K}$ concentrations on insects acts through a reduction in the accumulation of soluble carbohydrates and amino acids in leaves (Baskaran et al. 1985 ) and an increase in leaf sclerophylly (Dale 1988). High K concentrations can have adverse effects on the growth of lepidopterans (Denke et al. 2000) and aphids (Havlickova and Smetankova 1998). In this regard, leaf K concentrations have been observed to be correlated with some secondary metabolite concentrations, such as phenolics, quinic acid and tartaric acid, and altogether probably related to mechanisms of water use efficiency (Rivas-Ubach et al. 2012). These results reinforce the need of considering $\mathrm{K}$ in ecological stoichiometry studies (Sardans, Peñuelas et al. 2012; RivasUbach et al. 2012).

Leaf $\mathrm{P}$ concentrations were higher and leaf N:P ratios lower in earlysuccessional species, which in most cases are fast-growing species, than in mid- and late- successional species, which is consistent with the Growth Rate Hypothesis (GRH) of Elser et al. (2000). The differences in foliar N:P ratios among plants can have an evolutionary component driven by a long-term evolution towards a determined style of life (Willby et al. 2001; Sardans, Rivas-Ubach et al. 2012). On average, N leaf concentrations scale with a coefficient between 0.66 and 0.75 of $\mathrm{P}$ leaf concentrations 
(Niklas et al. 2005; Reich et al. 2010). The coefficient found here is smaller (0.33) but in any case, our results give further evidence that leaf $\mathrm{P}$ concentration increases more than leaf $\mathrm{N}$ concentration when both $\mathrm{N}$ and $\mathrm{P}$ leaf concentrations increase. This result fits well with the GRH because species with higher production capacity (higher $\mathrm{N}$ and $\mathrm{P}$ concentrations) have lower N:P ratio, thus coinciding higher plant growth rate capacity with lower leaf $\mathrm{N}: \mathrm{P}$ ratio both favouring fast growth rates. A complementary explanation of the increase in foliar $\mathrm{N}: \mathrm{P}$ concentrations across the successional gradient could come from a transition from $\mathrm{N}$ to $\mathrm{P}$ limitation. Some studies have suggested that after a disturbance, recovering tropical forests may be $\mathrm{N}$ limited (due to $\mathrm{N}$ losses from the disturbance) favouring species adapted to $\mathrm{N}$ limitation (and possibly with lower N:P ratios), and thereafter, during the succession, present a transition back to $\mathrm{P}$ limitation once returned to mature forest status (Vitousek and Howarth 1991; Davidson et al. 2007).

In other tropical rainforests, woody plants had leaf $\mathrm{N}: \mathrm{P}$ ratios in the range of those observed in this study suggesting a frequent limiting role of $\mathrm{P}$ in tropical forest as observed in several previous studies (Tanner et al. 1998; Reich and Oleksyn 2004; Wright et al. 2011; Baribault et al. 2012; Santiago et al. 2012). For example, leaf N:P ratios were 11.7-17.6 in an Australian rainforest (Asner et al. 2009), 17.2-26.1 in Central and South American rainforests (Townsend et al. 2007), and $21.4 \pm 1.0$ in tropical forests in Oahu, Hawaii (Peñuelas, Sardans, Llusia, Owen, Carnicer et al 2010).

Relationships among concentrations of elements, phenolics and tannins, LMA, and $A_{\text {mass }}$ The observed relationships among leaf $\mathrm{C}: \mathrm{N}, \mathrm{LMA}$ and $\mathrm{A}_{\text {mass }}$ are in agreement with the leaf 'economic spectrum' paradigm (Wright et al. 2004). Leaves with low nutrient concentrations allocated more $\mathrm{C}$ to the production of carbon-based secondary 
compounds such as phenolics and tannins, which is consistent with the "Excess Carbon Hypothesis" of Peñuelas and Estiarte (1998). A recent meta-analysis has demonstrated that plant traits other than secondary metabolites, such as for example morphological (e.g., number of branches, plant size) and physical resistance (e.g., latex, trichomes) more strongly predicted a species' susceptibility to herbivores (Carmona et al. 2010). Abiotic factors such as air temperature, drought, ozone levels and radiation might cause changes in total leaf phenolics and tannin concentrations because they are involved in mechanisms that protect against abiotic (Peñuelas and Estiarte 1998; Peñuelas et al. 1999) and biotic (Kurokawa and Nakashizuka 2008) stressors. However, the considerable variation among these compounds, and differences in the importance of specific phenolics and tannins in plant defenses, warrants further research to determine whether phenolics and tannins are important in the defense against folivory in these humid tropical forests.

There was an absence of apparent effects of total leaf phenolics and tannin concentrations on accumulated standing folivory. Some studies have observed a negative relationships between leaf phenolics concentrations and herbivore attack (Dudt and Shure 1994; Eichhom et al. 2007), however, other studies have observed that leaf phenolic concentration is only marginally correlated with levels of herbivore attack (Schuldt et al. 2012). Leaf phenolics synthesis can be induced by herbivore attack as observed in some plant species (Boege 2004). At this regard, the synthesis of phenolics in leaves with more accumulated standing folivory can prevent the observation of negative correlations between leaf phenolics and accumulated standing folivory. Leaf traits not measured in our study, e.g., concentrations of alkaloids, morphological traits, such as toughness, might have had a significant effect on the inter-specific variation in the extent of herbivory, but it is likely that there is a highly diverse range of defensive 
strategies among these very highly species-diverse forests. In this regard, it is important to consider that plants can counteract insect attack by mechanisms other than accumulating chemical defenses, e.g. by increasing the susceptibility of herbivores to predator and parasitoid attack (Havill and Raffa 2000; Heil et al. 2001).

\section{Leaf elemental concentrations}

Most leaf elemental concentrations of the 88 woody plant species in this study were similar to those in the leaves of rainforest tree species in other studies (Table S9, supporting information). Most of the leaf concentrations of some potentially toxic elements such as $\mathrm{As}, \mathrm{Cu}, \mathrm{Zn}, \mathrm{V}, \mathrm{Cr}, \mathrm{Ni}, \mathrm{Mo}, \mathrm{Cd}$, and $\mathrm{Pb}$ were within the range of concentrations observed in non-polluted areas throughout the world and considerably lower than the concentrations required to cause leaf damage (Sardans and Peñuelas 2007). The leaf concentrations of $\mathrm{As}, \mathrm{Cd}, \mathrm{Cu}, \mathrm{Sr}, \mathrm{Mo}, \mathrm{Pb}, \mathrm{Mo}$, and $\mathrm{Zn}$ were lower, and concentrations of $\mathrm{Cr}, \mathrm{Fe}, \mathrm{Mn}$, and $\mathrm{Ni}$ were higher than those observed in Hawaiian and Australian tropical forests (Table S9, supporting information).

Summarising, the results show a great heterogeneity in leaf composition in this tropical forest as observed in other studies (Townsend et al. 2008). Importantly, the results highlight that the leaf elemental concentrations and stoichiometry in this tropical forest are linked with different ecological strategies, including the adaptation to different successional stages and plant-herbivore relationships. Thus, as we hypothesized, the use of elements in different quantities and proportions can be underlying the great biodiversity of the tropical rainforest. Leaf elemental composition and stoichiometry are related with tree successional stage, leaf molecular composition, and leaf accumulated standing folivory. Moreover early successional species, mostly fast-growing species, had low leaf N:P concentration ratio as expected by the GRH. 
Furthermore, the leaf variables relationships fit well with the predictions of the 'leaf economic spectrum' and the relations between leaf $\mathrm{N}$ concentrations and total phenolics and total tannins fit with 'carbon excess' hypotheses. The results also show the importance considering $\mathrm{K}$ in stoichiometry ecological studies. Altogether, these results suggest that the different use of nutrients is a cause and/or an effect of the processes underlying in the niche fragmentation and high diversity of this ecosystem.

\section{Acknowledgements}

This research was supported by the Spanish Government projects CGC2010-17172 and Consolider Ingenio Montes (CSD2008-00040), by the Catalan Government project SGR 2009-458 and by the Estonian Ministry of Education Research (grant SF1090065s07). We thank Theodore Garland Jr. for providing the statistical programs used for phylogenetic analyses. We thank the Malaysian and Sabah Governments for their permission to conduct research in Malaysia; Waidi Sinun of Yayasan Sabah and his staff and Glen Reynolds of the Royal Society's South East Asian Rainforest Research Programme and his staff for logistical support at the Danum Valley Field Centre; the Danum Valley Management Committee for full approval and support of the research; the University Malaysia Sabah for cooperation; the UK NERC OP3/ACES research programme for logistical and infrastructure support. This is paper number SEARRP 521 of the Royal Society's South East Asian Rainforest Research Programme.

Notes on contributions

Josep Peñuelas is a professor, working on a range of issues related to plant ecology: plant ecophysiology, ecosystem functioning, plant-atmosphere and plant-herbivore interactions, ecological stoichiometry and ecometabolomics, and global ecology.

Jordi Sardans is a senior researcher, whose main research lines are the nutrient cycling, ecological stoichiometry and ecometabolomic studies in the frame of ecosystems structure and function and their responses to global change. 
Joan Llusia is a senior researcher, whose main research lines are the plant-atmosphere relationships. He has focused his main studies on the research of the terpene contentemission relationships with abiotic and biotic plant relationships,

Jorge Silva is a technician, specialised in the research linked to secondary organic metabolites and chemical ecology in general

Susan M. Owen is a research scientist, whose main research lines are VOCs in, all their biological and environmental aspects, and plant nutrient ecology.

B. Bala-Ola is a botanist who is interested in all the botanical aspects of the tropical forest flora.

Alona C Linatoc is a Ph.D. student. She is interested in all aspects of chemical ecology of tropical forest flora.

M. Noh Dalimin is a professor, interested in all aspects of global change ecology and in the chemical ecology of the tropical forests of south-east Asia.

Ülo Niinemets is a professor, interested in plant stress ecophysiology, physicalchemical-physiological traits of plant species, volatile isoprenoids, community ecology, remote sensing, and global change ecology.

\section{References}

Adams JM, Rehill B. Zhang Y, Gower J. 2009. A test of the latitudinal defense hypothesis: herbivory, tannins and total phenolics in four North American tree species. Ecological Research 24:697-704.

An H, Shangguan ZP. 2010. Leaf stoichiometry trait and specific leaf area of dominant species in the secondary succession of the loess plateau. Polish Journal of Ecology 58:103-113. 
Asner GP, Martin RE, Ford AJ, Metcalfe DL, Liddell MJ. 2009. Leaf chemical and spectral diversity in Australian tropical forest. Ecological Applications 19:216-253.

Baribault TW, Kobe RK, Finley AO. Tropical tree growth is correlated with soil phosphorus, potassium, and calcium, though not for legumes. Ecological Monographs 82:189-203.

Baskaran P, Narayanasamy P, Pari A. 1985. The role of potassium in incidence of insect pests among crop plants, with particular reference to rice. Role of Potassium in Crop Resistance to Insect Pests, Research Series no 3, pp. 63-68. Potash Research Institute of India, Guragaon, Haryana, India.

Boege K. 2004. Induced responses in three tropical dry forest plant species - direct and indirect effects on herbivory. Oikos: 107:541-548

Brearley FQ, Scholes, JD, Press MC, Palfner G. 2007. How does light and phosphorus fertilization affect the growth and ectomycorrhizal community of two contrasting Dipterocarp species? Plant Ecology 192:237-249.

Bryant JP, F. S., Chapin III FS, Klein DR. 1983. Carbon/nutrient balance of boreal plants in relation to vertebrate herbivory. Oikos 40:357-368.

Carmona, D., M. Lajeunesse, M. Johnson. 2010. Plant traits that predict resistance to herbivores. Functional Ecology 25:358-367.

Cockburn PF. 1976. Trees of Sabah, Vol. 1, Sabah Forest Record No. 10. Borneo Literature Bureau, Kuching, Malaysia.

Cockburn PF. 1980. Trees of Sabah, Vol. 2, Sabah Forest Record No. 10. Dewan Bahasa dan Pustaka Cawangan Sarawak, Kuching, Malaysia. 
Coley PD, Bryant JP, Chapin III FS. 1985. Resource availability and plant antiherbivore defense. Science 230:895-899.

Collins B, Wein G. 1998. Soil resource heterogeneity effects on early succession. Oikos $82: 238-245$.

Crone EE, Jones CG. 1999. The dynamics of carbon-nutrient balance: Effects of cottonwood acclimation to short-and long-term shade on beetle feeding preferences. Journal of Chemical Ecology 25:635-656.

Dale, D. 1988. Plant-mediated effects of soil mineral stress on insects. Plant StressInsect Interactions (ed. E.A. Heinrichs), pp. 35-110. John Wiley, AND Sons, USA.

Davidson EA, de Carvalho CJR, Figueira AM, Ishida FY, Ometto JPHB, Nardoto GB, Saba RT, Hatashi SN, Leal EC, Vieira ICG, Martinelli LA. 2007. Recupation of nitrogen cycling in Amazonian forest following agricultural abandonment. Nature 447:995-998.

Denke D, Schulthess F, Bonato O, Gounou S, Smith H. 2000. Effect of the application of potassium on the development, survival and fecundity of Sesamia colamistis Hampson and of Eldana sacharina Walker on maize. Insect Science and its Application 20:151-156.

Dial RJ, Ellwood MDF, Turner EC, Foster WA. 2006. Arthropod abundance, canopy structure, and microclimate in a Bornean lowland tropical rain forest. Biotropica 38:643-652.

Dudt JF, Shure DJ. 1994. The influence of light and nutrients on foliar phenolics and insect herbivory. Ecology 75:86-98.

Duvigneaud P, Denaeyer-De Smet S. 1968. Essai de classification chimique (Élements minéraux) des plantes gypsicoles du bassin de l'Ebre. Bulletin of the Society Royale Botanique Belgique 99:279-291. 
Eck G, B. Fiala B, Linsenmair, Hashim RB, Proksch P. 2001. Trade-off between chemical and biotic antiherbivore defense in the south East Asian plant Genus Macaranga. Journal of Chemical Ecology 27:1979-1996.

Eichhorn MP, Fagan KC, Compton SG, Dent DH, Hartley SE. 2007. Explaining leaf herbivory rates on tree seedlings in a Malaysian rain forest. Biotropica 39:416-421.

Elser JJ, Sterner RW, Gorokhova F, Fagan WF, Markov TA, Cotner JB, Harrison JF, Hobbie SE, Odell, GM, Weider LJ. 2000. Biological stoichiometry from genes to ecosystem. Ecology Letters 5:540-550.

Everard K, Seabloom EW, Harpole WS, de Mazancourt C. (2010) Plant water use affects competition for nitrogen: why drought favors invasive species in California. American Naturalist 175:85-97.

Feeny P. 1992. The evolution of chemical ecology: contributions from the study of herbivorus insects. In: Herbivores: their interaction with secondary plant metabolites. $2^{\text {nd }}$ Ed. Vol. II (eds. G.A: Rosenthal, AND M.R. Berenbaum), pp 1-44 Academic Press, Orlando, Florida.

Fincher RM, Dyer LA, Dôdson CD, Richards JL, Tobler MA, Searcy J, Mather J, Reid AJ, Rolig JS, Pideock W. 2008. Inter- and intraspecific comparisons of antiherbivore defenses in three species of rainforest understory shrubs. Journal of Chemical Ecology 34:558-574.

Gusewell S, Bollens U. 2003. Composition of plant species mixtures grown at various N:P ratios and levels of nutrient supply. Basic and Applied Ecology 4:453-466.

Harpole WS. Suding KN. 2011. A test of the niche dimension hypothesis in an arid annual grassland. Oecologia 166:197-205.

Havill NP, Raffa KF. 2000. Compound effects of induced plant responses on insect herbivores and parasitoids: implications for tritrophic interactions. Ecological Entomology 25:171-179. 
Havlickova H, Smetankova M. 1998. Effect of potassium and magnesium fertilization on barley preference by the bird cherry oat-aphid Rhopalosiphum padi (L.). Rostlinna Vyroba 44:379-383.

Heil M, Koch T, Hilpert A, Fiala B, Boland W, Linsenmair KE. 2001. Extrafloral nectar production of the ant-associated plant, Macaranga tanarius, ia an induced, indirect, defensive response elicited by jasmonic acid. Proceedings of the Natlional Academy of Science USA 98:1083-1088.

Herms DA, Mattson WJ. 1992. The dilemma of plants: to grow to defend. The Quarterly Review of Biology 67:283-335.

John R, Dalling JW, Harms KE, Yavitt JB, Stallard RF, Mirabello M, Hubbell SP, Navarrete H, Vallejo M, Foster RB. 2007. Soil nutrients influence spatial distributions of tropical tree species. Proceedings of the National Academy of Sciences of the United States of America 104:864-869.

Jones CG, Hartley SE. 1999. A protein competition model of Phenolic allocation. Oikos $86: 27-44$.

Köhler P, Ditzer T, Huth A. 2000. Concepts for the aggregation of tropical tree species into functional types and the application to Sabah's lowland rain forests. Journal of Tropical Ecology 16:591-602.

Kouki M, Manetas Y. 2002. Toughness is less important than chemical composition of Arbutus unedo leaves in food selection by Poecilimon species. New Phytologist 154:399-407.

Kurokawa H, Nakashizuka T. 2008. Leaf herbivory and decomposability in a Malaysian tropical rain forest. Ecology 89:2645-2656.

Kurokawa H, Kitahashi Y, Koike T, Lai J, Nakashizuka T. 2004. Allocation to defence or growth in dipterocarp forest seedlings in Borneo. Oecologia 140:261-270. 
Kusar TA, Coley PD. 1991. Nitrogen-content and expansion rate of young leaves of rain-forest species-implications for herbivory. Biotropica 23:141-150.

Kursar TA, Coley PD. 2003. Convergence in defense syndromes of young leaves in tropical rainforest. Biochemical Systematics and Ecology 31:929-949.

Laurance SGW, Laurance WF, Andrade A,Feamside PM, Harms KE, Vicentini A, Luizao RCC, 2010. Influence of soils and topography on Amazonian tree diversity: a landscape-scale study. Journal of Vegetation Science 21:96-106.

Long WX, Yang XB, Li DH. 2012. Patterns of species diversity and soil nutrients along a chronosequence of vegetation recovery in Hainan Island, South China. Ecological Research 27:561-568.

Llambi LD, Fontaine M, Rada F, Saugier B, Sarmiento L. 2003. Ecophysiological of dominant plant species during old-field succession in a high tropical Andean ecosystem. Arctic, Antarctic and Alpine Research 35:447-453.

Long WX, Yang XB, Li DH. 2012. Patterns of species diversity and soil nutrients along a chronosequence of vegetation recovery in Hainan Island, South China. Ecological Research 27:561-568.

Lowman MD. 1992. Herbivory in Australian rain forest, with particular reference to canopies of Doryphora sassafras (Monimiaceae). Biotropica 24:263-272.

Makkar HPS, Goodchild AV. 1996. Quantification of tannins: a laboratory manual. International Center for Agricultural Research in the Dry Areas (ICARDA), Aleppo.

Mamolos AP, Veresoglou DS, Barbayiannis N. 1995. Plant-species abundance and tissue concentrations of limiting nutrients in low-nutrient grassland-a test of competition theory. Journal of Ecology 83:485-495. 
Marigo G. 1973. Sur une méthode de fractionnement et d'estimation de composes phénoliques chez les végétaux. Analusis 2:106-110.

Meyer MW, Karasov WH. 1989. Antiherbivore chemistry of Larrea tridentate effects on woodrat (Neotoma lepida) feeding and nutrition. Ecology 70:953-951.

Mundim FM, Costa AN, Vasconcelos HL. 2009. Leaf nutrient content and host plant selection by leaf-cutter ants. Atta laevigata, in a Neotropical savanna. Entomologia Experimentalis et Applicata 130:47-54.

Niinemets Ü, Cescatti A, Rodeghiero M, Tosens T. 2005 Leaf internal diffusion conductance limits photosynthesis more strongly in older leaves of Mediterranean evergreen broad-leaved species. Plant Cell and Environment 28:1552-1566.

Niinemets Ü, Valladares F, Ceulemans R. 2003. Leaf-level phenotypic variability and plasticity of invasive Rhododendron ponticum and non-invasive Ilex aquifolium cooccurring at two contrasting European sites. Plant Cell and Environment 26:941-956.

Niinemets Ü, Wright IJ, Evans JR. 2009. Leaf mesophyll diffusion conductance in 35 Australian sclerophylls covering a broad range of foliage structural and physiological variation. Journal of Experimental Botany 60:2433-2449.

Niklas KJ, Owens T, Reich PB, Cobb ED. 2005. Nitrogen/phosphorus leaf stoichiometry and the scaling of plant growth. Ecology Letters 8:636-642.

Nomura M, Itioka T. 2002. Effects of synthesized tannin on the growth and survival of a generalist herbivorous insect, the common cutworm, Spodoptera litura Fabricius (Lepidoptera: Noctuidae). Applied Entomological Zoology 37:285-289.

Nomura N, Kikuzawa K. 2003. Productivity phenology of tropical montane forest: fertilization experiments along a moisture gradient. Ecological Research 18:573-586.

Novotny W, Basset Y, Miller SE, Weiblen GD, Bremer B, Cizek L, Drozd P. 2002. Low host specificity of herbivorous insects in a tropical forest. Nature 416:841-844. 
Paoli GD. 2006. Divergent leaf traits among congeneric tropical trees with contrasting habitat associations on Borneo. Journal of Tropical Ecology 22:397-408.

Paoli GD, Curran, LM, Zak DR. 2005. Phosphorus efficiency of Bornean rain forest productivity: evidence against the unimodal efficiency hypothesis. Ecology 86:15481561.

Paoli GD, Curran LM, Zak DR. 2006. Soil nutrients and beta diversity in the Bornean Dipterocarpaceae: evidence for niche partitioning by tropical rain forest trees. Journal of Ecology 94:157-170.

Peñuelas J, Estiarte M. 1998. Can elevated $\mathrm{CO}_{2}$ affect secondary metabolism and ecosystem functioning? Trends in Ecology and Evolution 13:20-24.

Peñuelas J, Estiarte M, Kimball BA. 1999. Flavonoid responses in wheat grown at elevated $\mathrm{CO}_{2}$ : green versus senescent leaves. Photosynthetica 37:615-619.

Peñuelas J, Sardans J, Llusia J, Owen S, Niinemets Ü. 2011. Lower P contents and more widespread terpene presence in old Bornean than in young Hawaiian tropical plant species guilds. Ecosphere 2:1-19.

Peñuelas J, Sardans J, Llusia Owen S, Carnicer J, Giambelluca TW, Rezende EL, Waite M, Niinemets Ü. 2010. Faster returns on "leaf economics" and different biogeochemical niche in invasive compared with native plant species. Global Change Biology 16:21712185.

Peñuelas J, Sardans J, Llusia J, Owen S, Silva J, Niinemets Ü. 2010. Higher allocation to low cost chemical defenses in invasive species of Hawaii. Journal of Chemical Ecology 36:1255-1270.

Peñuelas J, Sardans J, Ogaya R, Estiarte M. 2008. Nutrient stoichiometric relations and biogeochemical niche in coexisting plant species: effect of simulated climate change. Polish Journal of Ecology 56:613-622. 
Porter LJ, Hrstich LN, Chang BG. 1986. The conversion of procyanidins and prodelphinidins to cyanidin and delphinidin, Phytochemistry 25:223-230.

Reed JD. 1995. Nutritional toxicology of tannins and related polyphenols in forage legume. Journal of Animal Science 73:1516-1528.

Reich PB, Oleksyn J. 2004. Global patterns of plant leaf $\mathrm{N}$ and $\mathrm{P}$ in relation to temperature and latitude. Proceedings of the National Academy of Sciences of the United States of America 101:11001-11006.

Reich PB, Oleksyn J, Wright IJ, Niklas KJ, Hedin I, Elser JJ. 2010. Consistent 2/3power leaf nitrogen to phosphorus scaling among major plant groups and biomes. Proceedings of the Royal Society London B: Biological Sciences 277:877-883.

Rivas-Ubach A, Sardans J, Pérez-Trujillo M, Estiarte M, Peñuelas. J. 2012. Strong relationship between elemental sotichiometry and metabolome in plants. Proceedings of the Natlional Academy of Science USA 109:4181-4186.

Sahu SB, Dhal NK, Lal B, Mohanty RC. 2012) Differences in tree species diversity and soil nutrient status in a tropical sacred forest ecosystem on Niyamgiri hill range, Eastern Ghats, India. Journal of Mountain Science 9:492-500.

Santiago LS, Wright SJ, Herms KE, Yavitt JB, Korine C, Garcia MN, Turner BL. 2012. Tropical tree seedlings growth responses to nitrogen, phosphorus and potassium addition. Journal of Ecology 100:309-315.

Sardans J, Peñuelas J. 2007. Drought changes the dynamics of trace element accumulation in a Mediterranean Quercus ilex forest. Environmental Pollution 147:567583.

Sardans J, Peñuelas J, Coll M, Vayreda J, Rivas-Ubach A. 2012. Stoichiometry of potassium is largely determined by water availability and growth in Catalonian forests. Functional Ecology 26:1077-1089. 
Sardans J, Rivas-Ubach A, Peñuelas J. 2012. The elemental stoichiometry of aquatic and terrestrial ecosystems and its relationships with organismic lifestyle and ecosystem structure and function: a review and perspectives. Biogeochemistry. DOI 10.1007/s10533-011-9640-9.

Schuldt A, Baruffol M, Böhnke M, Bruelheide H, Härdtle W, Lang AC, Nadrowski K, von Ohimb G, Voigt W, Zhou H, Assmann T. 2010. Tree diversity promotes insect herbivory in subtropical forest of south-east China. Journal of Ecology 98:917-926.

Schuldt A, Bruielheide H, Durka W, Eichenberg D, Fischer M, Krober W, Hardtle W, Ma KP, Michalski SG, Palm WU, Schmid B, Welk E, Zhou HZ, Assmann T. 2012. Plant traits affecting herbivory on tree recruits in highly diverse subtropical forest. Ecology Letters 15:732-739.

Siddique I, Vieira ICG, Schmidt S, Lamb D, Carvalho CJR, Figuereido RD, Blomberg S, Davidson EA. 2010. Nitrogen and phosphorus additions negatively affect tree species diversity in tropical forest regrowth trajectories. Ecology 91:2121-2131.

Singleton VL, Rossi JA. 1965. Colorimetry of total phenolics with phosphomolybdicphosphotungstic acid reagents. American Journal of Enology and Viticulture 16:144158.

Soepadmo E, Shaw LG, Chung RCK. 2004. Tree flora of Sabah and Sarawak, Vol. 5. pp. 528. Sabah Forestry Department, Malaysia, Forest Research Institute Malaysia, Sarawak Forestry Department, Malaysia, Kuala Lumpur.

Stork NE. 1991. The composition of the arthropod fauna of Bornean lowland rain-forest trees. Journal of Tropical Ecology 7:161-180.

Tilman D. 1976. Ecological competition between algae: experimental comfirmation of resource-based competition theory. Science 192:463-465.

Tilman D, Wedin D. 1991. Plant traits and resource reduction for grasses growing on a nitrogen gradient. Ecology 72:685-700. 
Townsend AR, Cleveland CC, Asner GP, Bustamante MC. 2007. Controls over foliar $\mathrm{N}: \mathrm{P}$ ratios in tropical rainforest. Ecology 88:107-118.

Townsend AR, Asner GP, Cleveland CC. 2008. The biogeochemical heterogeneity of tropical forests. Trends in Ecology and Evolution 23:424-431.

Turner IM, Lucas PW, Becker P, Won SC, Yong WH, Choong MF, Tyree MT. 2000. Tree forest form in Brunei: a heath forest and a mixed Dipterocarp forest compared. Biotropica 32:53-61.

Venterink HO, Gusewell S. 2010. Competitive interactions between two meadow grasses under nitrogen and phosphorus limitation. Functional Ecology 24:877-886.

Vitousek PM, Howarth RW. 1991. Nitrogen limitation on land and in the sea-how can it occur. Biogeochemistry 13:87-115.

Webb CO, Donoghue MJ. 2005. Phylomatic: tree assembly for applied phylogenetics. Molecular Ecology Notes 5:181-183.

Whitmore TC. 1972. Tree Flora of Malaya. A manual for foresters, Vol. 1. pp. 473. Forest Department, Ministry of Primary Industries Malaysia, Longman Malaysia, Kuala Lumpur.

Willby NJ, Pulford ID, Flowers TH. 2001. Tissue nutrient signatures predict herbaceous-wetland community responses to nutrient availability. New Phytologist $152: 463-481$.

Wills C, Harms KE, Condit R, King D, Thompson J, He F, Muller-Landau HC, Ashton P, Losos E, Comita L, Hubbell S, Lafrankie J, Bunyavejchewin S, Dattaraja HS, Davies S, Esufali S, Foster R, Gunatilleke N, Gunatilleke S, Hall P, Itoh A, John R, Kiratiprayoon RS, De Lao SL, Massa M, Nath C, Noor MNS, Kassim AR, Sukumar R, Suresh HS, Sun IF, Tan S, Yamakura T, Zimmerman J. 2006. Non random processes maintain diversity in tropical forest. Science 311:527-531. 
Wright IJ, Reich PB, Westoby M, Ackerly DD, Baruch Z, Bongers F, Cavender-Bares J, Chapin T, Cornelissen JHC, Diemer M, Flexas M, Garnier J, Groom E, Gulias PK, Hikosaka J, Lamont K, Lee BB, Lee T, Lusk W, Midgley C, Navas JJ, Niinemets ML, Oleksyn Ü, Osada J, Porter N, Poot H, Prior L, Pyankov VI, Roumet C, Thomas SC, Tjoelker MG, Veneklaas EJ, Villar R. 2004. The Worldwide Leaf Economics Spectrum. Nature 428:821-827.

Wright SJ, Yavitt JB, Wurzburger N, Turner BL, Tanner EVJ, Sayer EJ, Santiago LS, Kaspari M, Hedin LO, Harms KE, García MN, Corre MD. 2011. Potassium, phosphorus, or nitrogen limit root allocation, tree growth, or litter production in a lowland tropical forest. Ecology 92:1616-1625.

Wu CC, Tsui CC, Hseih CF, Asio VC, Chen ZS. 2007. Mineral nutrient status of tree species in relation to environmental factors in the subtropical rain forest of Taiwan. Forest Ecology and Management 239:81-91.

Yamasaki M, Kikuzawa K. 2003. Temporal and spatial variations in leaf herbivory within a canopy of Fagus crenata. Oecologia 137:226-232.

Yan ER, Wang XH, Huang JJ. 2006. Shifts in plant nutrient use strategies under secondary forest succession. Plant and Soil 289:187-197. 


\section{Figure Captions}

Figure 1. Location of the Danum Valley field site in Borneo, Malaysia, and the phylogenetic tree for the 88 woody rain forest species studied. Acronyms of the species used in the other figures are indicated by two letters in bold type face after each species' name..

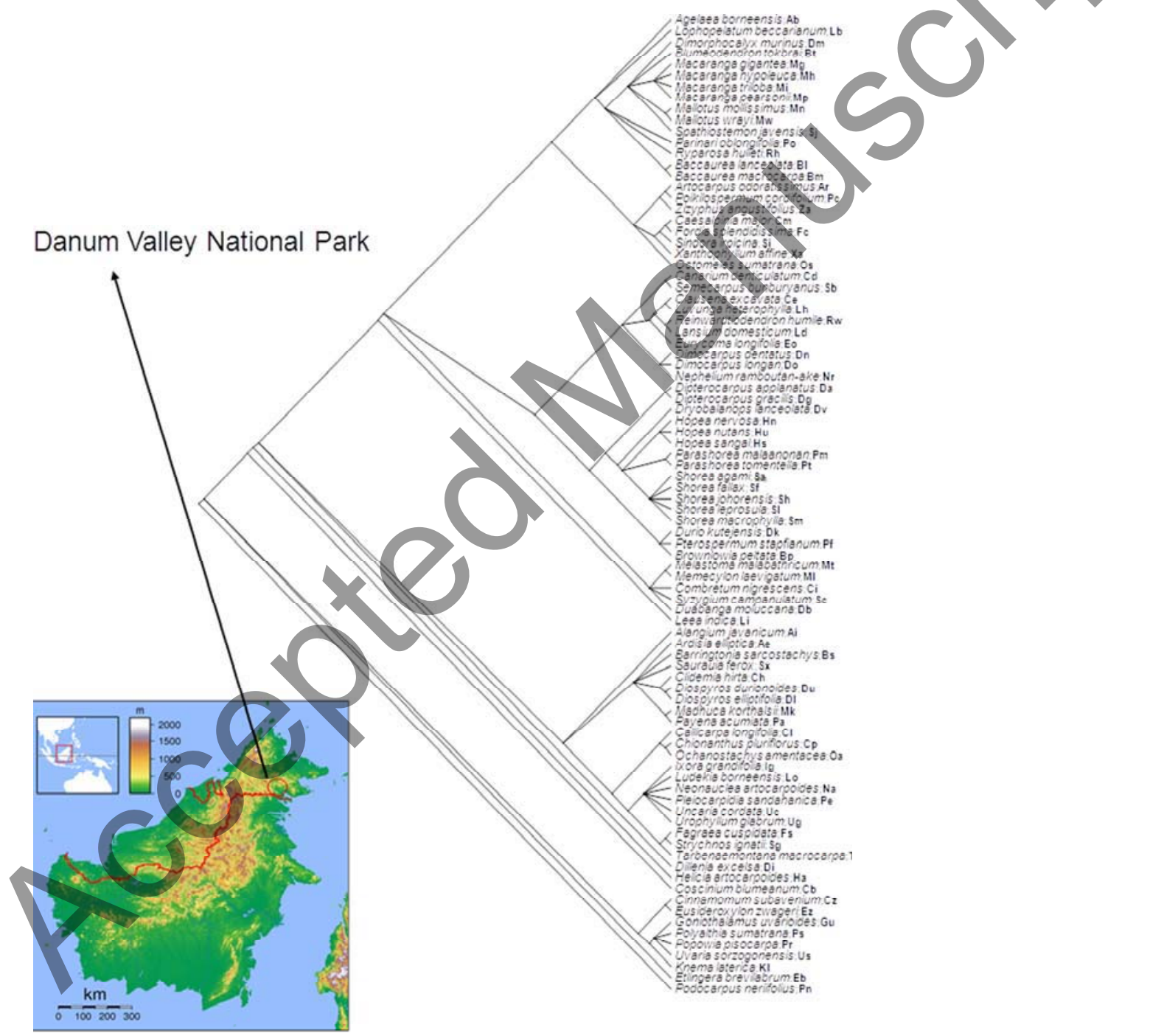


Figure 2. 'Biogeochemical niche', successional stages and folivory. (a) Principal component analysis of the leaf concentrations of the 20 elements analysed, and leaf N:P, $\mathrm{N}: \mathrm{K}$, and $\mathrm{P}: \mathrm{K}$ ratios of different 88 woody species. (b) Relationship between accumulated standing folivory and PC1 scores for each species (indication of their Biogeochemical niche). (c) PC2 scores in different successional stages. Different letter indicates statistically significant differences $(P<0.05)$. (Species acronyms defined in Figure 1).
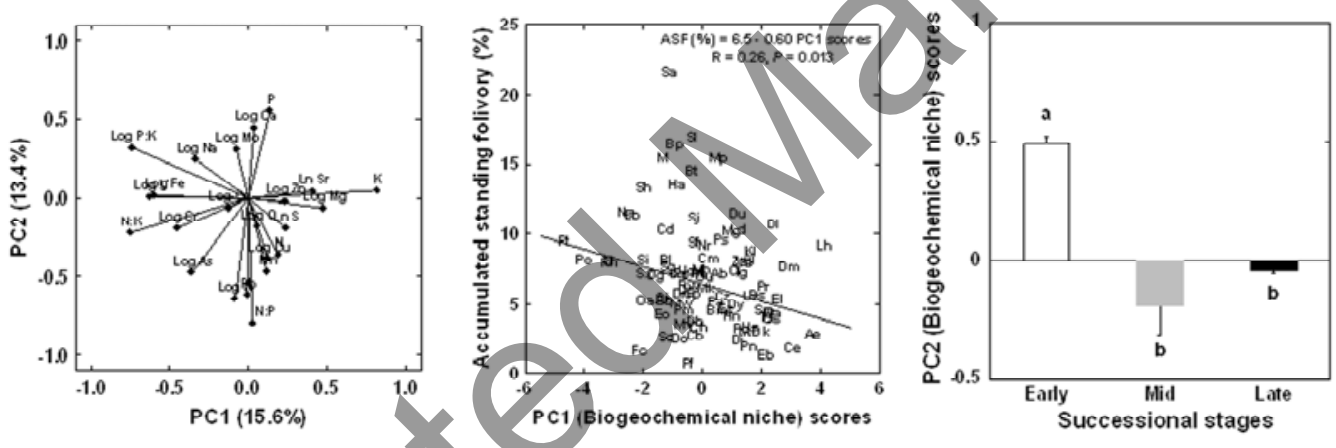
Figure 3. Relationship between accumulated standing folivory and leaf $[\mathrm{K}]_{\text {area }}$ among 88 woody species in the Bornean rainforest studied. (Species acronyms defined in Figure 1).

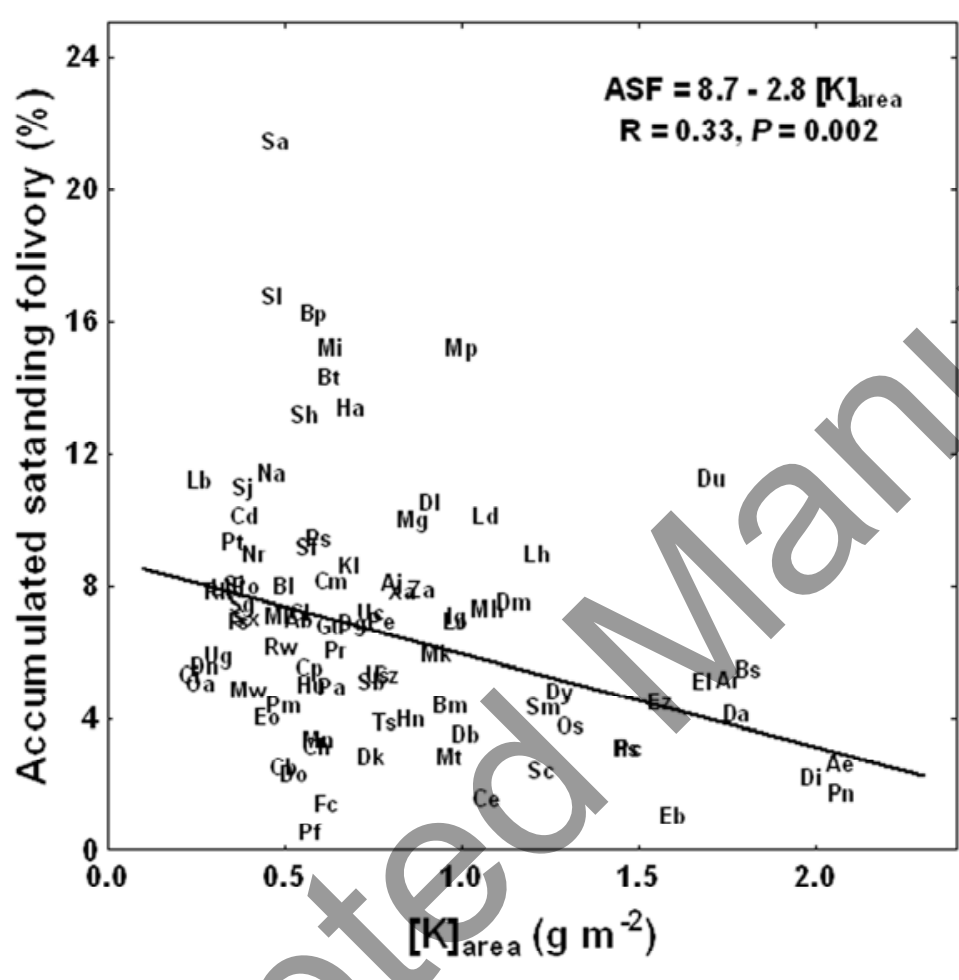


Figure 4. Leaf P concentrations and N:P ratio (means + S.E.) in the species of different successional stages. Different letters indicate significant differences (ANOVA, $P<$ $0.05)$.

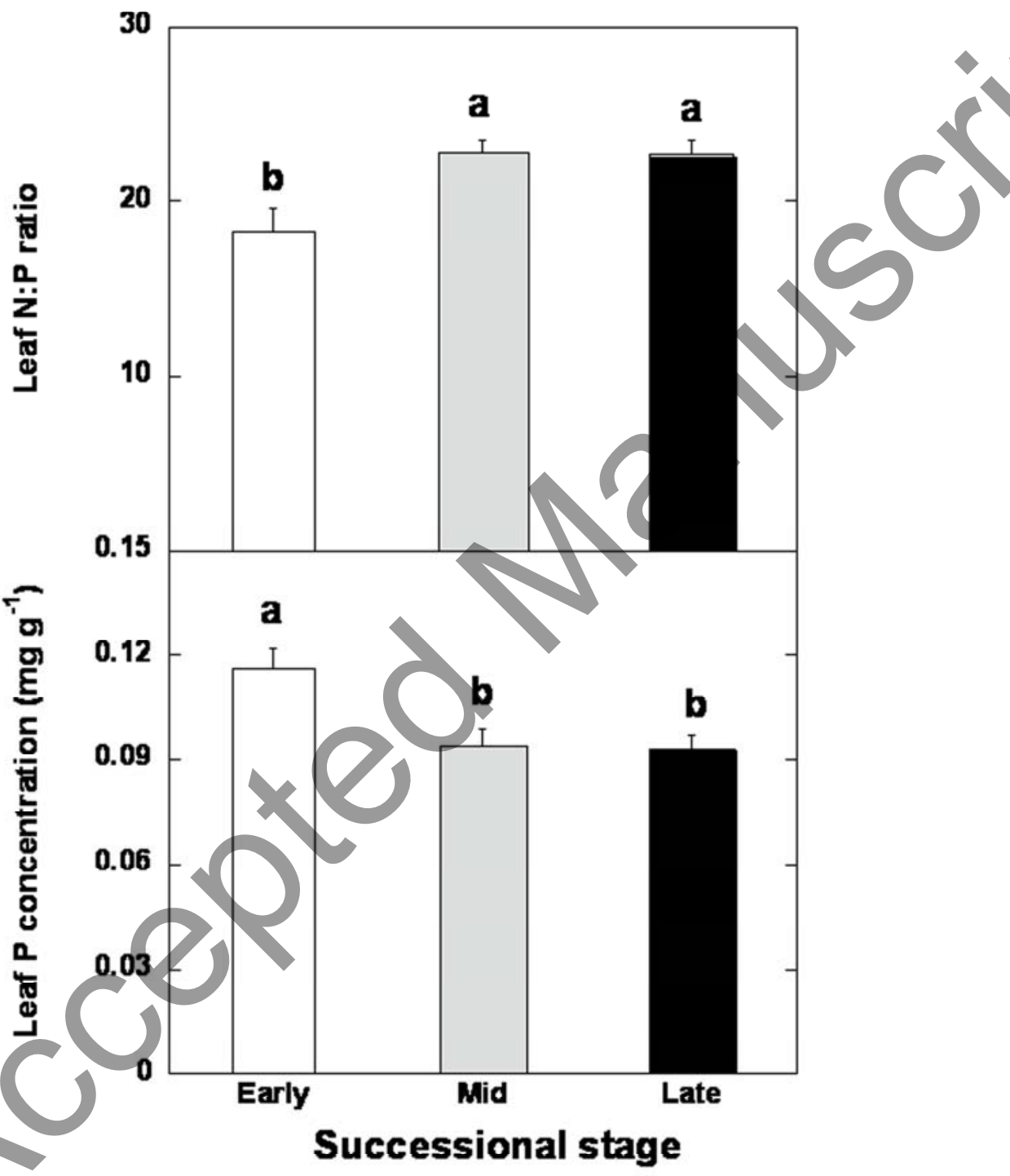


Figure 5. Relationships of LMA and $\mathrm{A}_{\text {mass }}$ (leaf photosynthetic capacity per unit of leaf weight) with foliar $\mathrm{N}$ concentrations (\% dry weight) among 88 woody rain forest species in the Danum Valley, Borneo . (Species acronyms defined in Figure 1).

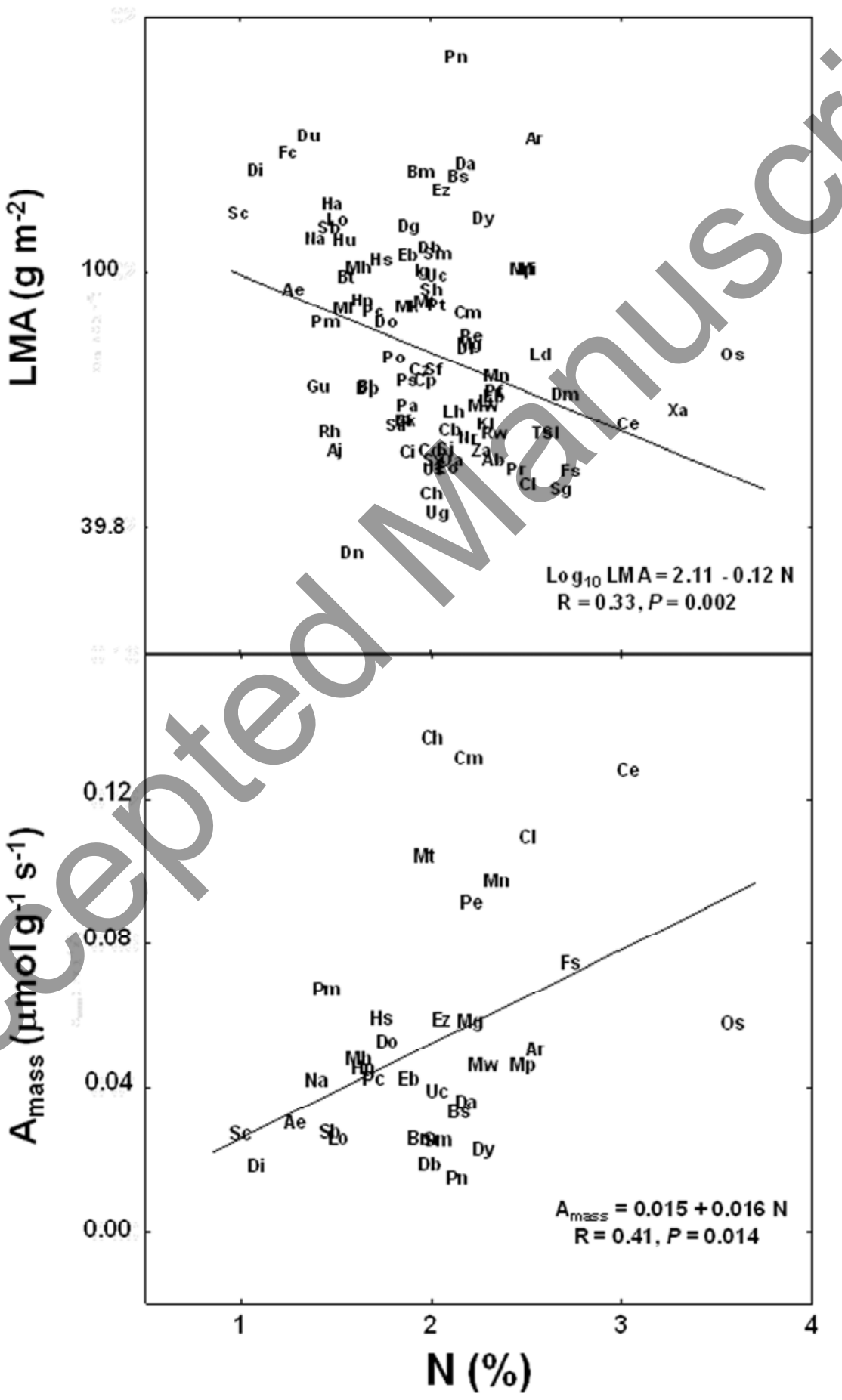


Figure 6. Relationships of concentrations of total leaf phenolics and leaf tannins with foliar $\mathrm{N}$ concentrations (\% dry weight) of 88 woody species woody rain forest species in the Danum Valley, Borneo. (Species acronyms defined in Figure 1).

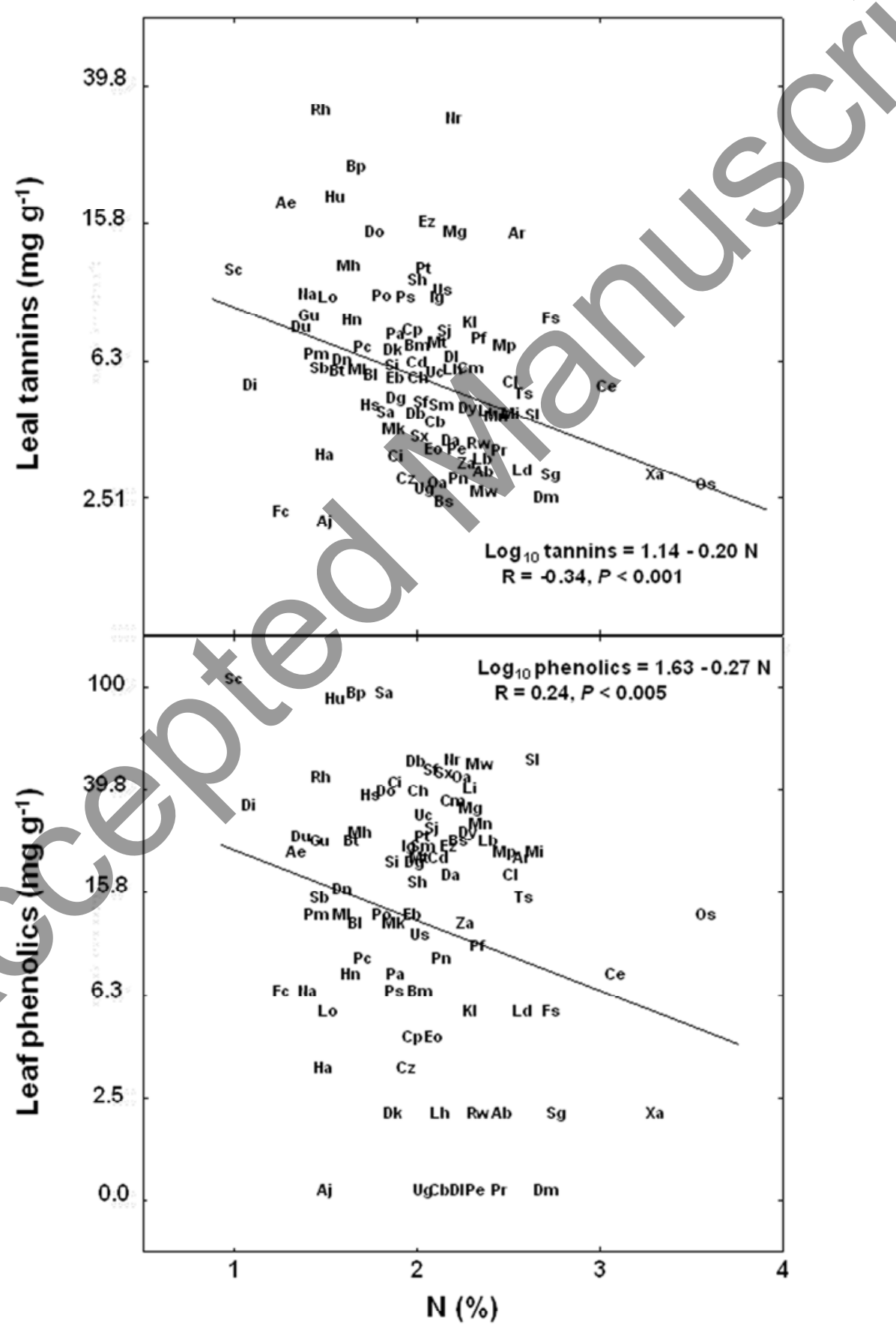




\section{Supporting information}

\section{Methods}

PHYLOGENETIC ANALYSES.- Species-specific averages were calculated for leaf structure, foliage concentrations of elements, phenolics, and tannins, and accumulated standing folivory. The program Phylomatic (Webb and Donoghue 2005) was used to create a phylogenetic tree that included the 88 woody species (Figure S1). Phylomatic assembles a phylogeny for the species of interest using a backbone plant megatree that is based on a variety of sources, primarily, DNA analyses. In our study, the phylogenetic hypothesis was based on a conservative megatree in which unresolved nodes were included as soft polytomies; i.e., multi-branches in the phylogeny that occurred because of insufficient phylogenetic information. To transform the phylogenetic tree into a matrix of phylogenetic distances, we used the Phenotype Diversity Analysis Program (PDAP) (Garland et al. 1993). Significant phylogenetic signals in the traits, i.e., the tendency of closely related species to resemble each other through a shared ancestry, were identified using the randomization procedure in the Matlab PHYSIG module developed by Blomberg et al. (2003), which compares the variance in independent phylogenetic contrasts in the real dataset against a null distribution derived from the phenotypic data after randomizing across the tips of the phylogeny, which breaks any pattern of phylogenetic resemblance between relatives). A phylogenetic signal was significant if the variance in the contrasts in the real dataset was lower than the variance in $95 \%$ of the permuted datasets. To make comparisons across traits, we used the $k$ statistic, which indicates how much phylogenetic signal is in the phenotypic data relative to the expectation based on a random walk model of phenotypic evolution (Blomberg et al. 2003). If $k=1$, then the phenotypic trait has 
exactly the amount of signal expected from the phylogenetic tree and it follows a random walk model (Brownian motion). If $k>1$, the phylogenetic resemblance is greater than expected, and if $k<1$, it less than expected. Those analyses determined whether phylogenetic correction was required in subsequent regression analyses. Generalized linear models (GLM) were used to identify the "significant" relationships among leaf elemental composition, $\mathrm{C}: \mathrm{N}: \mathrm{P}: \mathrm{K}$ stoichiometry, leaf morphological traits, physical and chemical defences, and accumulated standing folivory. When the dependent variable did not exhibit a significant phylogenetic signal, we used ordinary least square regressions (OLS); otherwise, phylogenetic generalized least square regressions (PGLS) were used. PGLS controls for phylogenetic relatedness by adjusting the expected variance/covariance of the regression residuals using the matrix of phylogenetic distances (which is mathematically equivalent to analyzing the data using phylogenetically independent contrasts). Those analyses were performed using the RegressionV2 module in Matlab 7.6.0 (Lavin et al. 2008). 
Table S1. Family, life form, height at maturity, and succesional stage of 88 woody species in the Danum Valley (Borneo). The acronym used for each species in the figures is shown in the first column together with the species name.

Species

Agelaea borneensis (Hook. f.) Merr. Ab

Alangium javanicum (BI.) Wang Ai

Ardisia elliptica Thunb. Ae

Artocarpus anisophyllus Ar

Baccaurea lanceolata (Miq.) Muell. Arg. BI

Baccaurea macrocarpa (Miq.) Muell. Arg. Bm

Barringtonia sarcostachys (BI.) Miq. Bs

Blumeodendron tokbrai (BI.) Kurz Bt

Brownlowia peltata Benth. Bp

Caesalpinia major (Medik.) Dandy and Exell $\mathbf{C m}$

Callicarpa longifolia Lamk. Cl

Canarium denticulatum $\mathrm{BI}$. Cd

Chionanthus pluriflorus (Knobl.) Kiew $\mathbf{C p}$

Cinnamomum subavenium Miq. $\mathbf{C z}$

Clausena excavata Burm. f. Ce

Clidemia hirta (L.) D. Don Ch

Combretum nigrescens King $\mathbf{C i}$

Coscinium blumeanum Miers ex Hook. f. and

Thomson $\mathbf{C b}$

Dillenia excelsa (Jack) Gilg. DI

Dimocarpus dentatus Meijer ex Leenh. Dn

Dimocarpus longan Lour. subsp. malesianus Leenh

Do

Dimorphocalyx murinus Elm. Dm

Diospyros durionoides Bakh. Du

Diospyros elliptifolia Merr. DI

Dipterocarpus applanatus Shooten Da

Dipterocarpus gracilis Blume Dg

Dryobalanops lanceolata Burck Dv

\begin{tabular}{|c|c|c|c|c|}
\hline Family & Life form & $\begin{array}{l}\text { Mature } \\
\text { height }(\mathrm{m})\end{array}$ & & $\begin{array}{l}\text { Suc } \\
\text { pos }\end{array}$ \\
\hline Connaraceae & liana/shrub & & & \\
\hline Alangiaceae & Tree & & & mid \\
\hline Myrsinaceae & Tree & & & \\
\hline Moraceae & tree & & 25 & mid \\
\hline Euphorbiaceae & tree & & 27 & mid \\
\hline Euphorbiaceae & tree & & 24 & mid \\
\hline Lecythidaceae & tree & & 24 & mid \\
\hline Euphorbiaceae & tree & & 24 & mid \\
\hline Tiliaceae & & & 20 & mid \\
\hline Leguminosae & 4 & & 3 & early \\
\hline Verbenaceae & shrut & & 5 & early \\
\hline Burseraceae & tree & & 30 & mid \\
\hline Oleaceae & tree & & 18 & mid \\
\hline Lauraceae & tree & & 35 & mid \\
\hline Rutaceae & tree & & 15 & early \\
\hline Melastomaceae & shrub & & 2 & early \\
\hline Combretaceae & liana & & & mid \\
\hline Menispermaceae & liana & & & mid \\
\hline Dilleniaceae & tree & & 35 & mid \\
\hline Sapindaceae & tree & & 15 & mid \\
\hline Sapindaceae & tree & & 30 & mid \\
\hline Euphorbiaceae & tree & & 15 & mid \\
\hline Ebenaceae & tree & & 25 & late \\
\hline Ebenaceae & tree & & 18 & late \\
\hline Dipterocarpaceae & tree & & 50 & late \\
\hline Dipterocarpaceae & tree & & 50 & late \\
\hline Dipterocarpaceae & tree & & 80 & late \\
\hline
\end{tabular}


Duabanga moluccana Blume Db

Durio kutejensis (Hassk.) Becc. Dk

\begin{tabular}{|c|c|c|c|}
\hline Lytraceae & tree & 45 & early \\
\hline Malvaceae & tree & 24 & $\mathrm{mic}$ \\
\hline Zingiberaceae & herb & 5 & \\
\hline Simaroubaceae & tree/shrub & 8 & \\
\hline Lauraceae & tree & 50 & \\
\hline Loganiaceae & tree & 18 & \\
\hline Leguminosae & tree/shrub & 5 & \\
\hline Annonaceae & shrub/tree & 15 & \\
\hline Proteaceae & tree & 25 & \\
\hline Dipterocarpaceae & tree & 30 & \\
\hline Dipterocarpaceae & tree & 40 & \\
\hline Dipterocarpaceae & tree & 40 & \\
\hline Rubiaceae & ruk & 18 & \\
\hline Myristicaceae & rub & 20 & \\
\hline Meliaceae & & 15 & \\
\hline Leeaceae & & 10 & \\
\hline Celastraceae & & 36 & \\
\hline $\begin{array}{l}\text { Rubiaceae } \\
\text { Rutaceae }\end{array}$ & & 25 & \\
\hline Euphorbiace & & 21 & \\
\hline & & & \\
\hline Euphorbiaceae & tree & 24 & \\
\hline Euphorbiaceae & tree & 22 & \\
\hline Euphorbiaceae & tree & 20 & \\
\hline Sapotaceae & tree & 35 & \\
\hline Euphorbiaceae & tree & 26 & \\
\hline Euphorbiaceae & shrub/tree & 12 & \\
\hline Melastomaceae & shrub & 2 & \\
\hline Melastomaceae & shrub/tree & 20 & \\
\hline Rubiaceae & tree & 20 & \\
\hline Sapindaceae & tree & 40 & \\
\hline Olacaceae & tree & 30 & \\
\hline Datiscaceae & tree & 70 & \\
\hline Dipterocarpaceae & tree & 60 & \\
\hline Dipterocarpaceae & & 65 & \\
\hline
\end{tabular}

Eurycoma longifolia Jack Eo

Eusideroxylon zwageri Teijsm. and Binn. Ez

Fagraea cuspidata Blume Fs

Fordia splendidissima (Blume ex Miq.) Buijsen Fc

Goniothalamus uvarioides King Gu

Helicia artocarpoides Elmer $\mathrm{Ha}$

Hopea nervosa King Hn

Hopea nutans Ridl. Hu

Hopea sangal Korth. Hs

Ixora grandifolia Zoll. and Moll. Ig

Knema latericia EImer KI

Lansium domesticum Correa Ld

Leea indica (Burm. f.) Merr. Li

Lophopetalum beccarianum Pierre Lb

Ludekia borneensis Ridsd. Lo

Luvunga heterophylla Merr. Lh

Macaranga gigantea (Reichb. f. and Zoll.) Muell. Arg.

Mg

Macaranga hypoleuca (Reichb. f. and Zoll.) Muell.

Arg. $\mathbf{M h}$

Macaranga pearsonii Merr. Mp

Macaranga triloba (Thunb.) Mull. M

Madhuca korthalsii (Pierre) Lam. Mk

Mallotus mollissimus (Geisel.) Airy Shaw Mn

Mallotus wrayi King ex Hook. f. Mw

Melastoma malabathricum L. Mt

Memecylon laevigatum Blume MI

Neonauclea artocarpoides Ridsd. Na

Nephelium ramboutan-ake (Labill.) Leenh. Nr

Ochanostachys amentacea Mast

Octomeles sumatrana Miq. Os

Parashorea malaanonan (Blanco) Merr. Pm

Parashorea tomentella (Symingt.) Meijer $\mathrm{Pt}$

Dipterocarpaceae

tree

65 late 
Parinari oblongifolia Hk. f. Po

Payena acuminata (BI.) Pierre Pa

Pleiocarpidia sandahanica Brem. Pe

Podocarpus neriifolius D. Don Pn

Poikilospermum cordifolium (Barg.-Petr.) Merrill Pc

Polyalthia sumatrana (Miq.) Kurz Ps

Popowia pisocarpa (BI.) Endl. Pr

Pterospermum stapfianum Ridl. Pf

Reinwardtiodendron humile (Hassk.) Mabb. Rw

Ryparosa hulletii King. Rh

Saurauia ferox Korth. Sx

Semecarpus bunburyanus Gibbs Sb

Shorea agami P. S. Ashton Sa

Shorea fallax Meijer Sf

Shorea johorensis Foxw. Sh

Shorea leprosula Miq. S

Shorea macrophylla (de Vriese) P. S. Ashton Sm

Sindora irpicina de Wit $\mathbf{S i}$

Spathiostemon javensis BI. Sj

Strychnos ignatii Bergius Sg

Syzygium campanulatum Korth. Sc

Tabernaemontana macrocarpa Jack Ts

Uncaria cordata (Lour.) Merr. Uc

Urophyllum glabrum Wall. sensu Ridl. Ug

Uvaria sorzogonensis C. Presl. Us

Xanthophyllum affine Korth. Xa

Zizyphus angustifolius (Miq.) Hatusima ex Steen Za
Chrysobalanaceae tree

Sapotaceae tree

Rubiaceae

Podocarpaceae tree

Urticaceae liana

Annonaceae tree

Annonaceae shrub/tree

Malvaceae tree

Meliaceae

Flacourtiaceae

Actinidiaceae

Anacardiaceae

Dipterocarpaceae

Dipterocarpaceae

Dipterocarpaceae

Dipterocarpaceae

Dipterocarpaceae tree

Leguminosae

Euphorbiaceae

Loganiaceae

Myrtaceae

Apocynaceae shrub/tree

Rubiaceae

Rubiaceae

Annonaceae

Polygalaceae

Rhamnaceae tree

tree

tree

tree

tree

tree

tree

tree

tree

liana

shrub/tree

liana

tree

tree
40 mid

30 mid

15 early

6 late

10 late

25 mid

27 mid

15 mid

5 mid

15 early

50 late

50 late

50 late

60 late

45 mid

40 mid

17 mid

35 mid

30 early

30 mid

early

5 mid

mid

30 late

$30 \mathrm{mid}$ 
Table S2. Foliar bioelement concentrations (mean; S.E. between brackets) in 88 woody plant species in the Bornean rainforest studied ( $\mathrm{n}=3$ sets of 6-37 leaves each).

\begin{tabular}{|c|c|c|c|c|c|c|c|c|}
\hline Species & $C(\%)$ & $\mathbf{N}(\%)$ & Ca (\%) & $\mathbf{K}(\%)$ & $\mathbf{M g}(\%)$ & $\mathbf{S}(\%)$ & $\mathbf{P}(\%)$ & \\
\hline Agelaea bor & & & & & & & & (13.4) \\
\hline Alangium javanicu & $\begin{array}{l}3.7 \\
.1)\end{array}$ & $\begin{array}{l}1.50 \\
(0.01)\end{array}$ & $\begin{array}{c}0.44 \\
(0.01)\end{array}$ & $\begin{array}{l}1.60 \\
(0.01)\end{array}$ & 0.18 & $\begin{array}{c}0.19 \\
(0.003)\end{array}$ & $\begin{array}{l}0.12 \\
(0.001)\end{array}$ & $\begin{array}{l}44.0 \\
(0.2)\end{array}$ \\
\hline Ardisia elliptic & 0 & $\begin{array}{l}1.29 \\
(0.27)\end{array}$ & $\begin{array}{l}1.27 \\
(0.12)\end{array}$ & $\begin{array}{l}2.30 \\
(0.25)\end{array}$ & $\begin{array}{c}0.63 \\
(0.08)\end{array}$ & $\begin{array}{c}0.11 \\
(0.01)\end{array}$ & $\begin{array}{l}0.08 \\
(0.01)\end{array}$ & $\begin{array}{l}39.7 \\
(5.4)\end{array}$ \\
\hline $\begin{array}{l}\text { Artocarpus } \\
\text { anisophyllus }\end{array}$ & 2 & $\begin{array}{l}2.55 \\
(0.05)\end{array}$ & $\begin{array}{l}1.3 \\
(0.1\end{array}$ & $\begin{array}{l}1.13 \\
(0.11)\end{array}$ & $\begin{array}{c}0.13 \\
(0.07)\end{array}$ & $\begin{array}{c}0.16 \\
(0.00)\end{array}$ & $\begin{array}{c}0.12 \\
(0.003)\end{array}$ & $\begin{array}{c}139 \\
(13.3)\end{array}$ \\
\hline ccaurea lanceolata & 5) & $\begin{array}{l}1.66 \\
(0.20)\end{array}$ & $\begin{array}{l}2.1 \\
(0.7\end{array}$ & & & & $\begin{array}{c}0.08 \\
(0.005)\end{array}$ & \\
\hline $\begin{array}{l}\text { Baccaurea } \\
\text { macrocarpa }\end{array}$ & & $\begin{array}{l}1.96 \\
(0.48)\end{array}$ & $\begin{array}{l}1.8 \\
(0.2\end{array}$ & & & & $\begin{array}{l}8 \\
1)\end{array}$ & \\
\hline $\begin{array}{l}\text { Barri } \\
\text { sarco }\end{array}$ & & & & & & & & $(\angle 0.1)$ \\
\hline $\begin{array}{c}\text { Blumeodendron } \\
\text { tokbrai }\end{array}$ & & & 2. & & & $\begin{array}{l}0.28 \\
(0.13)\end{array}$ & & $\begin{array}{l}80.0 \\
(33.3)\end{array}$ \\
\hline Brownlowia peltata & & & & & & $\begin{array}{l}0.19 \\
(0.06)\end{array}$ & $\begin{array}{l}0 \\
77)\end{array}$ & \\
\hline C & & & & & ) & & & \\
\hline Callicarpa longifc & & & & & & & & \\
\hline $\begin{array}{l}\text { Canarium } \\
\text { denticulatum }\end{array}$ & & & & & 0. & & & \\
\hline $\begin{array}{r}\text { Chio } \\
\text { plu }\end{array}$ & & & & $\begin{array}{l}0.88 \\
(0.22)\end{array}$ & & & & \\
\hline $\begin{array}{l}\text { Cinn } \\
\text { sub }\end{array}$ & & $\begin{array}{l}1.95 \\
(0.19)\end{array}$ & 0 & & & & & \\
\hline Clausena excava & & & & & & & & \\
\hline Clid & 47. & $\begin{array}{r}2.01 \\
(0.04)\end{array}$ & $\begin{array}{l}0.6 \\
(0.0\end{array}$ & & & & & \\
\hline & & $1 \varepsilon$ & & & & & & \\
\hline $\begin{array}{l}\text { Cos } \\
\text { blum }\end{array}$ & & $\begin{array}{l}2.11 \\
(0.17)\end{array}$ & $\begin{array}{l}0 . \\
(0 .\end{array}$ & & & & & \\
\hline & & $\begin{array}{r}1.0 \\
(0.0\end{array}$ & $\begin{array}{l}0.8 \\
0.8\end{array}$ & & & & & \\
\hline 年 & & & & & & & & \\
\hline Dimorphocalyx & 47 & $\begin{array}{c}2.71 \\
(0.07)\end{array}$ & & & & & & \\
\hline os durion & & & & & & & & \\
\hline Diospyrus elliptifoli & 4 & $\begin{array}{l}2.15 \\
(0.07\end{array}$ & 1. & & 0. & & & 3) \\
\hline $\begin{array}{l}\text { Dipterocarpus } \\
\text { applanatus }\end{array}$ & & & & & & & & $\begin{array}{c}47.0 \\
(25.7)\end{array}$ \\
\hline ipterocarpus gracilis & 53 & $\begin{array}{l}1.89 \\
(0.05)\end{array}$ & $\begin{array}{c}0.88 \\
(0.03)\end{array}$ & & & & & \\
\hline $\begin{array}{c}\text { Dryobalanops } \\
\text { lanceolata }\end{array}$ & & $\begin{array}{l}2.28 \\
(0.32)\end{array}$ & $\begin{array}{c}0.90 \\
(0.12)\end{array}$ & $\begin{array}{c}1.10 \\
(0.21)\end{array}$ & 0.58 & $\begin{array}{c}0.20 \\
(0.04)\end{array}$ & & $\begin{array}{l}81.3 \\
(9.3)\end{array}$ \\
\hline banga mo & 47.4 & $\begin{array}{l}2.00 \\
(0.01)\end{array}$ & 1.20 & & & & & \\
\hline Duric & $\begin{array}{l}46.4 \\
(0.6\end{array}$ & $\begin{array}{l}1.87 \\
(0.16)\end{array}$ & $\begin{array}{l}0.76 \\
(0.14)\end{array}$ & $\begin{array}{l}1.33 \\
(0.15)\end{array}$ & $\begin{array}{c}0.50 \\
(0.08)\end{array}$ & $\begin{array}{c}0.17 \\
(0.01)\end{array}$ & $\begin{array}{c}0.07 \\
(0.01)\end{array}$ & $\begin{array}{l}54.3 \\
(3.8)\end{array}$ \\
\hline
\end{tabular}




\begin{tabular}{|c|c|c|c|c|c|c|c|c|}
\hline Etlingera brevilab & $\begin{array}{l}46.5 \\
(1.1)\end{array}$ & $\begin{array}{c}1.89 \\
(0.22)\end{array}$ & $\begin{array}{c}1.22 \\
(0.49)\end{array}$ & $\begin{array}{c}1.57 \\
(0.20)\end{array}$ & $\begin{array}{c}0.39 \\
(0.12)\end{array}$ & $\begin{array}{c}0.15 \\
(0.003)\end{array}$ & $\begin{array}{c}0.09 \\
(0.00)\end{array}$ & $\begin{array}{l}57.3 \\
(9.3)\end{array}$ \\
\hline $\begin{array}{c}\text { Euphoria malaiensis = } \\
\text { Dimocarpus longan }\end{array}$ & $\begin{array}{l}51.4 \\
(0.5)\end{array}$ & $\begin{array}{l}1.41 \\
(0.04)\end{array}$ & $\begin{array}{c}0.77 \\
(0.08)\end{array}$ & $\begin{array}{l}1.13 \\
(0.08)\end{array}$ & $\begin{array}{l}0.25 \\
(0.02)\end{array}$ & $\begin{array}{l}0.15 \\
(0.01)\end{array}$ & $\begin{array}{c}0.10 \\
(0.00)\end{array}$ & $\begin{array}{c}47.3 \\
(0.03)\end{array}$ \\
\hline Eurycoma longifolia & $\begin{array}{l}44.2 \\
(1.2)\end{array}$ & $\begin{array}{l}2.09 \\
(0.07)\end{array}$ & $\begin{array}{c}0.40 \\
(0.05)\end{array}$ & $\begin{array}{l}0.96 \\
(0.22)\end{array}$ & $\begin{array}{c}0.27 \\
(0.01)\end{array}$ & $\begin{array}{c}0.14 \\
(0.003)\end{array}$ & $\begin{array}{c}0.10 \\
(0.02)\end{array}$ & $\begin{array}{l}118 \\
(31.9)\end{array}$ \\
\hline $\begin{array}{c}\text { Eusideroxylon } \\
\text { zwageri }\end{array}$ & $\begin{array}{l}46.6 \\
(0.9)\end{array}$ & $\begin{array}{l}2.06 \\
(0.16)\end{array}$ & $\begin{array}{c}0.97 \\
(0.19)\end{array}$ & $\begin{array}{c}1.21 \\
(0.26)\end{array}$ & $\begin{array}{c}0.40 \\
(0.09)\end{array}$ & $\begin{array}{l}0.13 \\
(0.01)\end{array}$ & $\begin{array}{c}0.12 \\
(0.00)\end{array}$ & $\begin{array}{l}76.7 \\
(4.7)\end{array}$ \\
\hline Fagraea cuspidata & $\begin{array}{l}47.2 \\
(1.0)\end{array}$ & $\begin{array}{l}1.26 \\
(0.13)\end{array}$ & $\begin{array}{l}1.11 \\
(0.25)\end{array}$ & $\begin{array}{c}0.42 \\
(0.12)\end{array}$ & $\begin{array}{c}0.20 \\
(0.02)\end{array}$ & $\begin{array}{c}0.11 \\
(0.01)\end{array}$ & $\begin{array}{c}0.07 \\
(0.03)\end{array}$ & $\begin{array}{c}70.3 \\
(11.9)\end{array}$ \\
\hline Fordia splendidis & $\begin{array}{l}49.9 \\
(0.2)\end{array}$ & $\begin{array}{l}2.74 \\
(0.17)\end{array}$ & $\begin{array}{c}0.23 \\
(0.04)\end{array}$ & $\begin{array}{l}0.80 \\
(0.06)\end{array}$ & $\begin{array}{l}0.17 \\
(0.04)\end{array}$ & $\begin{array}{l}0.17 \\
(0.01)\end{array}$ & $\begin{array}{c}0.09 \\
(0.01)\end{array}$ & $\begin{array}{l}61.3 \\
(4.9)\end{array}$ \\
\hline $\begin{array}{c}\text { Goniothalamus } \\
\text { uvarioides }\end{array}$ & $\begin{array}{l}47.8 \\
(1.7)\end{array}$ & $\begin{array}{c}1.41 \\
(0.20)\end{array}$ & $\begin{array}{c}1.09 \\
(0.56)\end{array}$ & $\begin{array}{l}1.00 \\
(0.31)\end{array}$ & $\begin{array}{c}0.16 \\
(0.04)\end{array}$ & $\begin{array}{l}0.15 \\
(0.05)\end{array}$ & $\begin{array}{c}0.06 \\
(0.004)\end{array}$ & $\begin{array}{c}64.3 \\
(14.2)\end{array}$ \\
\hline Helicia artocarpo & $\begin{array}{l}45.5 \\
(0.9)\end{array}$ & $\begin{array}{l}1.49 \\
(0.05)\end{array}$ & $\begin{array}{c}0.51 \\
(0.07)\end{array}$ & $\begin{array}{c}0.56 \\
(0.02)\end{array}$ & $\begin{array}{c}0.39 \\
(0.02)\end{array}$ & $\begin{array}{c}0.13 \\
(0.02)\end{array}$ & $\begin{array}{c}0.04 \\
(0.00)\end{array}$ & $\begin{array}{l}53.7 \\
(6.4)\end{array}$ \\
\hline Hopea nervos & $\begin{array}{l}48.1 \\
(1.5)\end{array}$ & $\begin{array}{c}1.65 \\
(0.09)\end{array}$ & $\begin{array}{c}1.41 \\
(0.53)\end{array}$ & & $\begin{array}{c}0.38 \\
(0.19)\end{array}$ & $\begin{array}{c}0.17 \\
(0.03)\end{array}$ & $\begin{array}{c}0.10 \\
(0.01)\end{array}$ & $\begin{array}{l}75.5 \\
(13.7)\end{array}$ \\
\hline Hopea & $\begin{array}{l}51.8 \\
(0.2)\end{array}$ & $\begin{array}{l}1.56 \\
(0.05)\end{array}$ & $\begin{array}{c}0.76 \\
(0.10)\end{array}$ & $\begin{array}{c}0.54 \\
(0.06)\end{array}$ & $\begin{array}{c}0.22 \\
(0.01)\end{array}$ & $\begin{array}{c}0.16 \\
(0.01)\end{array}$ & $\begin{array}{c}0.06 \\
(0.002)\end{array}$ & $\begin{array}{l}61.0 \\
(10.0)\end{array}$ \\
\hline Hopea sangal & $\begin{array}{l}49.1 \\
(1.8)\end{array}$ & $\begin{array}{c}1.75 \\
(0.14)\end{array}$ & $\begin{array}{c}0.82 \\
(0.24)\end{array}$ & & $\begin{array}{c}0.39 \\
(0.13)\end{array}$ & $\begin{array}{c}0.18 \\
(0.03)\end{array}$ & $\begin{array}{c}0.11 \\
(0.02)\end{array}$ & $\begin{array}{c}84.7 \\
(15.3)\end{array}$ \\
\hline dif & $\begin{array}{l}48.0 \\
(1.3)\end{array}$ & $\begin{array}{l}1.96 \\
(0.52)\end{array}$ & $\begin{array}{l}1.47 \\
(0.15)\end{array}$ & $\begin{array}{c}1.02 \\
(0.19)\end{array}$ & $\begin{array}{r}0.35 \\
(0.06)\end{array}$ & $\begin{array}{l}0.20 \\
(0.05)\end{array}$ & $\begin{array}{c}0.05 \\
(0.006)\end{array}$ & $\begin{array}{l}37.0 \\
(3.5)\end{array}$ \\
\hline Knema lateric & $\begin{array}{l}57.2 \\
(6.5)\end{array}$ & $\begin{array}{c}2.29 \\
(0.39)\end{array}$ & $\begin{array}{c}0.69 \\
(0.21)\end{array}$ & $\begin{array}{c}1.23 \\
(0.21)\end{array}$ & $\begin{array}{c}0.43 \\
(0.10)\end{array}$ & $\begin{array}{c}0.17 \\
(0.02)\end{array}$ & & $\begin{array}{l}41.3 \\
(9.9)\end{array}$ \\
\hline Lansium domesticum & $\begin{array}{l}47.8 \\
(0.3)\end{array}$ & $\begin{array}{l}2.58 \\
(0.04)\end{array}$ & $\begin{array}{l}0.99 \\
(0.11)\end{array}$ & $\begin{array}{l}1.50 \\
(0.25)\end{array}$ & $\begin{array}{l}0.43 \\
(0.08)\end{array}$ & $\begin{array}{c}0.18 \\
(0.01)\end{array}$ & $\begin{array}{c}0.14 \\
(0.01)\end{array}$ & $\begin{array}{c}94.7 \\
(24.7)\end{array}$ \\
\hline Leea ir & $\begin{array}{l}50.6 \\
(0.9)\end{array}$ & $\begin{array}{c}2.29 \\
(0.76)\end{array}$ & $\begin{array}{c}0.48 \\
(0.02)\end{array}$ & & $\begin{array}{c}0.24 \\
(0.03)\end{array}$ & $\begin{array}{c}0.12 \\
(0.02)\end{array}$ & & $\begin{array}{c}108 \\
(44.1)\end{array}$ \\
\hline $\begin{array}{l}\text { Lopho } \\
\text { beccal }\end{array}$ & & $\begin{array}{l}2.34 \\
(0.51)\end{array}$ & & $\begin{array}{l}0.43 \\
(0.03)\end{array}$ & $\begin{array}{c}0.44 \\
(0.07)\end{array}$ & & $\begin{array}{l}0.10 \\
(0.01)\end{array}$ & $\begin{array}{l}38.0 \\
(3.6)\end{array}$ \\
\hline Ludekia borneen & $\begin{array}{l}50.7 \\
(0.4)\end{array}$ & & $\begin{array}{l}1.00 \\
(0.21)\end{array}$ & $\begin{array}{c}0.85 \\
(0.13)\end{array}$ & & & & $\begin{array}{l}41.3 \\
(6.9)\end{array}$ \\
\hline Ivunga heterophylla & $\begin{array}{l}49.7 \\
(0.3)\end{array}$ & $\begin{array}{c}2.13 \\
(0.04)\end{array}$ & $\begin{array}{c}0.70 \\
(0.14)\end{array}$ & $\begin{array}{l}2.10 \\
(0.06)\end{array}$ & $\begin{array}{c}0.54 \\
(0.05)\end{array}$ & $\begin{array}{c}0.18 \\
(0.02)\end{array}$ & $\begin{array}{c}0.07 \\
(0.001)\end{array}$ & $\begin{array}{l}59.0 \\
(7.5)\end{array}$ \\
\hline Macaranga gigante & & $\begin{array}{l}2.21 \\
(0.20)\end{array}$ & $\begin{array}{c}1.35 \\
(0.28)\end{array}$ & $\begin{array}{l}1.17 \\
(0.15)\end{array}$ & $\begin{array}{c}0.55 \\
(0.15)\end{array}$ & & & $\begin{array}{l}82.7 \\
(9.3)\end{array}$ \\
\hline (2) & & $\begin{array}{l}1.63 \\
(0.30)\end{array}$ & $\begin{array}{c}0.64 \\
(0.09)\end{array}$ & & & & & $\begin{array}{l}73.5 \\
(9.1)\end{array}$ \\
\hline & & $\begin{array}{c}2.51 \\
(0.01)\end{array}$ & $\begin{array}{c}0.81 \\
(0.00)\end{array}$ & & $\begin{array}{c}0.26 \\
(0.00)\end{array}$ & & & $\begin{array}{l}68.0 \\
(0.5)\end{array}$ \\
\hline & & 2.49 & 1.35 & & & & & 80.0 \\
\hline & $\begin{array}{l}44.9 \\
(1.4)\end{array}$ & $\begin{array}{c}1.88 \\
(0.13)\end{array}$ & $\begin{array}{c}0.46 \\
(0.02)\end{array}$ & & $\begin{array}{c}0.31 \\
(0.03)\end{array}$ & $\begin{array}{c}0.38 \\
(0.12)\end{array}$ & & $\begin{array}{c}130 \\
(236)\end{array}$ \\
\hline & & $\begin{array}{c}2.35 \\
(0.38)\end{array}$ & $\begin{array}{c}2.20 \\
(0.46)\end{array}$ & & $\begin{array}{c}0.41 \\
(0.06)\end{array}$ & & & $\begin{array}{c}151 \\
(155)\end{array}$ \\
\hline alotu & 4 & 2.28 & 0.76 & 0.6 & 0 & 0 & 0.09 & 77.7 \\
\hline$M$ & & 1. & 1. & & 0. & 0 & & $\begin{array}{c}(12.8) \\
77.5\end{array}$ \\
\hline $\begin{array}{r}m a l \\
M\end{array}$ & 4 & & & & & & & $\begin{array}{c}(21.8) \\
44.7\end{array}$ \\
\hline & & & & & & & & (1.3) \\
\hline $\begin{array}{l}\text { Neonauclea } \\
\text { artocarnioides }\end{array}$ & 47.6 & $\begin{array}{c}1.40 \\
(019)\end{array}$ & $\begin{array}{c}1.60 \\
(025)\end{array}$ & $\begin{array}{c}0.43 \\
(0.01)\end{array}$ & 0.43 & $\begin{array}{c}0.16 \\
(0.01)\end{array}$ & 0.08 & $\begin{array}{c}127 \\
(156)\end{array}$ \\
\hline The & & 2.2 & & 0. & 0.5 & 0 . & 0. & \\
\hline & & & & & & & & J) \\
\hline $\begin{array}{c}\text { Ochanostachys } \\
\text { amentacea }\end{array}$ & $\begin{array}{l}50.9 \\
(0.5)\end{array}$ & $\begin{array}{c}2.12 \\
(0.09)\end{array}$ & $\begin{array}{c}0.14 \\
(0.02)\end{array}$ & $\begin{array}{c}0.54 \\
(0.04)\end{array}$ & $\begin{array}{c}0.12 \\
(0.02)\end{array}$ & $\begin{array}{c}0.15 \\
(0.01)\end{array}$ & $\begin{array}{c}0.08 \\
(0.001)\end{array}$ & $\begin{array}{l}55.0 \\
(4.0)\end{array}$ \\
\hline
\end{tabular}




\begin{tabular}{|c|c|c|c|c|c|c|c|c|}
\hline meres sumti & 9.4 & 3.59 & 0.93 & 1.83 & $\begin{array}{c}0.38 \\
(0.09)\end{array}$ & 0.17 & 0.16 & $\begin{array}{c}102 \\
(26.8)\end{array}$ \\
\hline Parashorea & $\begin{array}{l}\text { (U.0) } \\
47.0\end{array}$ & 1.46 & 1.39 & 0.63 & 0.37 & 0.19 & 0.07 & 73.0 \\
\hline malonaanan & $(0.6)$ & $(0.44)$ & $0.42)$ & $0.14)$ & $(0.11)$ & $0.01)$ & $0.03)$ & 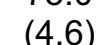 \\
\hline Parashorea & 5.5 & 2.04 & 1.67 & 0.4 & 0.18 & 0.16 & 0.10 & 'son \\
\hline \multirow[t]{2}{*}{ tomentella } & .6) & $(0.10)$ & $(0.41)$ & $(0$. & $(0.06)$ & $(0.01)$ & $(0.01)$ & 91.7) \\
\hline & & & & 0. & 0.19 & 0. & 0.07 & 261 \\
\hline \multirow[t]{2}{*}{ Parinari oblongifolia } & $(1.1)$ & $(0.21)$ & $(0.11)$ & $(0.08)$ & $(0.07)$ & $(0.03)$ & $(0.00)$ & (178) \\
\hline & 2.0 & 1.89 & 0.48 & 1.07 & 0.22 & 0.17 & 0.06 & 64.7 \\
\hline ayena acumina & $(0.7)$ & $(0.06)$ & $(0.09)$ & $(0.09)$ & $(0.02)$ & $(0.01)$ & $(0.003)$ & $(11.8)$ \\
\hline \multirow{3}{*}{ sandahanica } & 45.4 & 2.2 & 1.20 & 1. & 0.35 & 0.27 & 0. & \\
\hline & $(0.5)$ & $(0.17)$ & $(0.10)$ & $(0.08)$ & $(0.04)$ & $(0.07)$ & $(0.01)$ & (31.7) \\
\hline & 7.2 & 2.14 & & 0.99 & 0.44 & 0.22 & 0.10 & \\
\hline docarpus neriifolius & $(1.5)$ & $(0.08)$ & $(0.33)$ & $(0.21)$ & $(0.15)$ & $(0.08)$ & $(0.00)$ & $(6.4)$ \\
\hline \multirow{3}{*}{$\begin{array}{l}\text { Poikilospermum } \\
\text { cordifolium }\end{array}$} & & 1. & & 1. & 0. & 0.22 & & \\
\hline & & $(0$ & $(0$ & $(0.3$ & $(0.16)$ & $(0.02)$ & & $(5$ \\
\hline & 8 & 1.88 & 0.68 & 0.93 & 0.20 & 0.15 & 0.07 & 51.0 \\
\hline \multirow[t]{2}{*}{ Polyalthia sumatrana } & $(0.5)$ & $(0.01)$ & $(0$. & $(0.09)$ & $(0.00)$ & $(0.01)$ & $(0.0$ & $(2.6)$ \\
\hline & & 2.46 & & & 0.43 & & & 61.0 \\
\hline isocar & $(0.03)$ & $(0.10)$ & $(0.09)$ & $(0.12)$ & $(0.04)$ & $(0.01)$ & $(0.004)$ & (3.6) \\
\hline Ptero & 47.3 & & 2.03 & & 0.23 & 0.20 & 0.18 & 73.3 \\
\hline stap & $(0.4)$ & $(0$. & $(0$. & $(0$. & $(0.05)$ & $(0.0$ & $(0.04)$ & (14.2) \\
\hline \multirow{3}{*}{$\begin{array}{l}\text { Reinwardtiodendron } \\
\text { humile }\end{array}$} & 47.3 & 2. & 2. & 0. & 0.23 & 0.20 & 0.18 & 73.3 \\
\hline & $(0.7)$ & $(0$ & $(0$. & $(0.17)$ & & $(0.01)$ & $(0$. & (1) \\
\hline & & & & 0.58 & 1 & 0.15 & 0.08 & 132 \\
\hline \multirow[t]{2}{*}{ Ryparosa hulletii } & $(1.6)$ & $(0$. & $(0.62)$ & $(0.12)$ & $(0.04)$ & $(0.02)$ & $(0.01)$ & $(41.4)$ \\
\hline & & 2.0 & 1. & 0. & 0.1 & 0. & 0. & 124 \\
\hline Saurauia ferox & $(2.9)$ & $(0.08)$ & $(0.66)$ & $(0.00)$ & $(0.02)$ & $(0.08)$ & $(0.01)$ & $(51.1)$ \\
\hline \multirow{3}{*}{$\begin{array}{l}\text { Semecarpus } \\
\text { bunburyanus }\end{array}$} & 6 & 1. & 1.0 & 0. & 0.29 & & 0.15 & 45.7 \\
\hline & & $(0$ & & $(0.09)$ & $(0.03)$ & $(0$. & $(0.03)$ & $(6.2)$ \\
\hline & & & & & 0.2 & 0. & 0. & \\
\hline \multirow[t]{2}{*}{ Shorea agami } & (1.18) & $(0.19)$ & $(0.18)$ & $(0.20)$ & $(0.07)$ & $(0.01)$ & $(0.02)$ & (46.5) \\
\hline & & & & 0.84 & 0. & & & \\
\hline \multirow[t]{2}{*}{ Shorea fallax } & .8) & $(0.23)$ & $(0.3$ & $(0.25)$ & $(0.02)$ & $(0.1$ & $(0.01)$ & $(41.1)$ \\
\hline & & & 1. & 0.6 & 0.3 & 0. & 0. & 138 \\
\hline \multirow[t]{2}{*}{ Shorea johorensis } & $(0.2)$ & $(0.15)$ & $(0.25)$ & $(0.07)$ & $(0$ & $(0$. & $(0 . c)$ & $(41.1)$ \\
\hline & & & & $0 . \varepsilon$ & 0. & 0. & 0 & 60.0 \\
\hline \multirow[t]{2}{*}{ Shorea leprosula } & & $(0.06)$ & $(0.07)$ & $(0.05)$ & $(0.05)$ & $(0.01)$ & $(0.003)$ & $(4.0)$ \\
\hline & & & $1 . \varepsilon$ & & & & & 50.0 \\
\hline \multirow[t]{2}{*}{ Shorea macrophylla } & $(0$. & $(0$. & $(0$. & $(0$ & $(0$. & $(0$ & $(0$. & $(0.7)$ \\
\hline & & 1. & 0.77 & 0.64 & 0.22 & 0. & 0.08 & 126 \\
\hline & $(0.4)$ & $(0.21)$ & $(0.09)$ & $(0.04)$ & $(0.05)$ & $(0.02)$ & $(0.01)$ & $(80.6)$ \\
\hline \multirow{3}{*}{$\begin{array}{c}\text { Spathiostemon } \\
\text { javensis }\end{array}$} & 48.2 & 2.08 & 1.2 & 0.75 & 0.30 & 0.23 & 0.09 & 71.3 \\
\hline & & & & 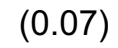 & $(0$. & $(0$ & $(0$ & 9) \\
\hline & 46. & 2.6 & 1.1 & 0.8 & 0.4 & 0.27 & 0.0 & 68.0 \\
\hline \multirow{2}{*}{$\begin{array}{c}\text { Stychnos ignatii } \\
\text { Syzygium }\end{array}$} & $(0.6)$ & & & & 1) & & & (9.1) \\
\hline & 50.6 & 1.00 & 0.7 & 1. & 0.10 & 0. & 0.09 & 45 \\
\hline campanulatc & & & & & & $(0$ & $(0$. & 1 \\
\hline arbernaemontana & 50.8 & 2.59 & 0.6 & 1.4 & 0.31 & 0.29 & 0.09 & 53.7 \\
\hline mac & $(0.6)$ & $(0.08)$ & $(0.11)$ & $(0.12)$ & $(0.04)$ & $(0.01)$ & $(0.01)$ & (5.6) \\
\hline & 51.7 & 2. & 0.6 & 0.7 & 0. & 0. & 0.08 & 58.3 \\
\hline Uncar & & & & $(0$. & $(0$. & $(0$. & $(0$. & $(9$. \\
\hline & & 2.04 & 0.64 & 0.79 & 0.21 & 0.20 & 0.08 & 58.3 \\
\hline phyllu & $(0.84)$ & $(0.22)$ & $(0.16)$ & $(0.05)$ & $(0.16)$ & $(0.02)$ & $(0.01)$ & (6.6) \\
\hline & 47 & & 0.3 & 1. & 0.2 & 0. & 0.1 & 70.3 \\
\hline ria sc & (3.1) & $(0.12)$ & $(0.07)$ & $(0$. & $(0.03)$ & $(0.003)$ & $(0.01)$ & (3.2) \\
\hline & 47.9 & 3. & 0.37 & 1.43 & 0.17 & 0.23 & 0.11 & 45.7 \\
\hline hop & $(0.62)$ & $(0.34)$ & $(0.1$ & $(0.29)$ & $(0.01)$ & $(0.01)$ & $(0.03)$ & (3.5) \\
\hline & & & 0.5 & 1. & 0.3 & 0.17 & 0.13 & 82.3 \\
\hline Zizyphus a & (2.3) & $(0.60)$ & $(0.33)$ & $(0.17)$ & $(0.06)$ & $(0.01)$ & $(0.02)$ & (30.6) \\
\hline
\end{tabular}


Table S3. Foliar trace element concentrations in 88 woody plant species (mean; S.E. between brackets) in the Bornean rainforest studied ( $\mathrm{n}=3$ sets of 6-37 leaves each).

\begin{tabular}{|c|c|c|c|c|c|c|c|c|c|c|c|}
\hline Species & $\begin{array}{c}\mathrm{Mn} \\
\left(\mathrm{mg} \mathrm{kg}^{-1}\right)\end{array}$ & $\underset{\left(\mathrm{mg} \mathrm{kg}^{-1}\right)}{\mathbf{V}}$ & $\begin{array}{c}\mathrm{Cr} \\
\left(\mathrm{mg} \mathrm{kg}^{-1}\right)\end{array}$ & $\underset{\left(\mathrm{mg} \mathrm{kg}^{-1}\right)}{\mathbf{N i}}$ & $\underset{\left(\mathrm{mg} \mathrm{kg}^{-1}\right)}{\mathrm{Cu}}$ & $\underset{\left(\mathrm{mg} \mathrm{kg}^{-1}\right)}{\mathbf{Z n}}$ & $\begin{array}{c}\text { As } \\
\left(\mathrm{mg} \mathrm{kq}^{-1}\right)\end{array}$ & $\begin{array}{c}\mathrm{Sr} \\
\left(\mathrm{mg} \mathrm{kq}^{-1}\right)\end{array}$ & Mo & 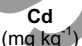 & $\begin{array}{c}\mathrm{Pb} \\
\left(\mathrm{mg} \mathrm{kg}^{-1}\right)\end{array}$ \\
\hline Agelaea borneensis & $\begin{array}{l}1161 \\
(141)\end{array}$ & $<0.200$ & $\begin{array}{l}4.5 \\
(2.1)\end{array}$ & $\begin{array}{l}22.7 \\
(5.6)\end{array}$ & $\begin{array}{l}18.3 \\
(1.8)\end{array}$ & $\begin{array}{l}19.8 \\
(1.7)\end{array}$ & $\begin{array}{l}0.103 \\
(0.001)\end{array}$ & $\begin{array}{l}27 \\
(6.4)\end{array}$ & & $\begin{array}{l}0.147 \\
(0.042)\end{array}$ & $\begin{array}{l}0.603 \\
(0.399)\end{array}$ \\
\hline Alangium javanicum & $\begin{array}{l}199 \\
(5)\end{array}$ & $\begin{array}{c}0.222 \\
(0.003)\end{array}$ & $\begin{array}{l}0.6 \\
(0.1)\end{array}$ & $\begin{array}{l}2.5 \\
(0.4)\end{array}$ & $\begin{array}{l}6.7 \\
(0.0)\end{array}$ & $\begin{array}{l}13.0 \\
(0.1)\end{array}$ & $\begin{array}{c}0.084 \\
(0.003)\end{array}$ & $\begin{array}{l}32 \\
(1)\end{array}$ & & $\begin{array}{l}0.123 \\
(0.004)\end{array}$ & $\begin{array}{c}0.202 \\
(0.006)\end{array}$ \\
\hline Ardisia elliptica & $\begin{array}{l}20 \\
(0)\end{array}$ & $<0.200$ & $\begin{array}{l}0.4 \\
(0.1)\end{array}$ & $\begin{array}{c}1.1 \\
(0.4)\end{array}$ & $\begin{array}{l}3.1 \\
(0.9)\end{array}$ & $\begin{array}{l}9.2 \\
(0.9)\end{array}$ & $\begin{array}{c}0.111 \\
(0.002)\end{array}$ & $\begin{array}{l}53 \\
(16)\end{array}$ & $\begin{array}{l}0.209 \\
(0.003)\end{array}$ & $\begin{array}{c}0.154 \\
(0.010)\end{array}$ & $\begin{array}{c}0.210 \\
(0.008)\end{array}$ \\
\hline $\begin{array}{l}\text { Artocarpus } \\
\text { anisophyllus }\end{array}$ & $\begin{array}{l}92 \\
(7)\end{array}$ & $\begin{array}{c}0.205 \\
(0.003)\end{array}$ & $\begin{array}{l}9.2 \\
(0.5)\end{array}$ & $\begin{array}{l}5.1 \\
(0.1)\end{array}$ & $\begin{array}{l}6.1 \\
(0.3)\end{array}$ & $\begin{array}{l}12.3 \\
(3.1)\end{array}$ & $\begin{array}{l}0.165 \\
(0.002)\end{array}$ & (4) & $\begin{array}{c}0.500 \\
(0.067)\end{array}$ & $\begin{array}{c}0.130 \\
(0.002)\end{array}$ & $\begin{array}{c}0.270 \\
(0.047)\end{array}$ \\
\hline $\begin{array}{l}\text { Baccaurea } \\
\text { lanceolata }\end{array}$ & $\begin{array}{l}166 \\
(28)\end{array}$ & $\begin{array}{c}0.270 \\
(0.070)\end{array}$ & $\begin{array}{l}21.0 \\
(8.9)\end{array}$ & $\begin{array}{l}5.7 \\
(2.0)\end{array}$ & $\begin{array}{c}5.8 \\
(1.2)\end{array}$ & $\begin{array}{l}21.3 \\
(6.8)\end{array}$ & & (22) & $\begin{array}{l}0.237 \\
(0.037)\end{array}$ & $\begin{array}{l}0.106 \\
(0.011)\end{array}$ & $\begin{array}{c}0.240 \\
(0.040)\end{array}$ \\
\hline $\begin{array}{l}\text { Baccaurea } \\
\text { macrocarpa }\end{array}$ & $\begin{array}{c}364 \\
(174)\end{array}$ & $<0.200$ & $\begin{array}{c}0.8 \\
(0.3)\end{array}$ & $\begin{array}{l}8.8 \\
(2.1)\end{array}$ & $\begin{array}{l}9.0 \\
(2.0)\end{array}$ & $\begin{array}{c}27.0 \\
(10.0)\end{array}$ & 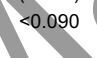 & (20) & $\begin{array}{l}0.255 \\
(0.033)\end{array}$ & $\begin{array}{c}0.165 \\
(0.006)\end{array}$ & $\begin{array}{c}0.360 \\
(0.027)\end{array}$ \\
\hline $\begin{array}{l}\text { Barringtonia } \\
\text { sarcostachys }\end{array}$ & $\begin{array}{l}1020 \\
(978)\end{array}$ & $\begin{array}{l}0.207 \\
(0.007)\end{array}$ & $\begin{array}{l}1.0 \\
(0.4)\end{array}$ & $\begin{array}{c}2.6 \\
(0.8)\end{array}$ & $\begin{array}{l}9.7 \\
(1.4)\end{array}$ & & & $\begin{array}{c}69 \\
(45)\end{array}$ & $\begin{array}{c}0.221 \\
(0.013)\end{array}$ & $\begin{array}{c}0.121 \\
(0.002)\end{array}$ & $\begin{array}{c}0.373 \\
(0.149)\end{array}$ \\
\hline $\begin{array}{l}\text { Blumeodendron } \\
\text { tokbrai }\end{array}$ & $\begin{array}{c}696 \\
(244)\end{array}$ & $\begin{array}{l}0.217 \\
(0.017)\end{array}$ & $\begin{array}{c}0.6 \\
(0.2)\end{array}$ & $\begin{array}{l}2.7 \\
(1.6)\end{array}$ & $\begin{array}{c}5.3 \\
(1.1)\end{array}$ & $\begin{array}{l}10.2 \\
(3.6)\end{array}$ & $<0.090$ & $\begin{array}{l}118 \\
(74)\end{array}$ & $\begin{array}{c}0.290 \\
(0.090)\end{array}$ & $\begin{array}{l}0.110 \\
(0.012)\end{array}$ & $\begin{array}{c}0.266 \\
(0.043)\end{array}$ \\
\hline Brownlowia peltata & $\begin{array}{c}187 \\
(105)\end{array}$ & $\begin{array}{c}0.223 \\
(0.023)\end{array}$ & $\begin{array}{c}3.2 \\
(1.8)\end{array}$ & $\begin{array}{l}1.6 \\
(0.5)\end{array}$ & $\begin{array}{l}4.6 \\
(0.8)\end{array}$ & $\begin{array}{l}15.0 \\
(2.5)\end{array}$ & $\begin{array}{c}0.150 \\
(0.012)\end{array}$ & $\begin{array}{l}22 \\
(7)\end{array}$ & $\begin{array}{c}0.211 \\
(0.023)\end{array}$ & $<0.100$ & $\begin{array}{c}0.211 \\
(0.032)\end{array}$ \\
\hline Caesalpinia major & $\begin{array}{l}1151 \\
(345)\end{array}$ & $\begin{array}{l}0.268 \\
(0.026)\end{array}$ & $\begin{array}{l}0.3 \\
(0.1)\end{array}$ & $\begin{array}{l}2.6 \\
(0.2)\end{array}$ & $\begin{array}{l}13.3 \\
(0.9)\end{array}$ & $\begin{array}{l}12.3 \\
(1.3)\end{array}$ & $<0.090$ & $\begin{array}{l}123 \\
(27)\end{array}$ & $\begin{array}{l}0.276 \\
(0.09)\end{array}$ & $<0.100$ & $\begin{array}{l}0.217 \\
(0.017)\end{array}$ \\
\hline Callicarpa longifolia & $\begin{array}{l}1534 \\
(918)\end{array}$ & $\begin{array}{l}0.213 \\
(0.022)\end{array}$ & $\begin{array}{l}0.6 \\
(0.4)\end{array}$ & $\begin{array}{l}2.6 \\
(1.0)\end{array}$ & $\begin{array}{l}12.0 \\
(2.1)\end{array}$ & $\begin{array}{l}36.0 \\
(13.1)\end{array}$ & $<0.090$ & $\begin{array}{c}51 \\
(11)\end{array}$ & $\begin{array}{c}0.207 \\
(0.007)\end{array}$ & $\begin{array}{c}0.103 \\
(0.011)\end{array}$ & $<0.200$ \\
\hline $\begin{array}{l}\text { Canarium } \\
\text { denticulatum }\end{array}$ & $\begin{array}{l}104 \\
(54)\end{array}$ & $\begin{array}{c}0.287 \\
(0.033)\end{array}$ & $\begin{array}{l}3.0 \\
(0.1)\end{array}$ & $\begin{array}{l}8.3 \\
(3.2)\end{array}$ & $\begin{array}{l}6.6 \\
(0.6)\end{array}$ & $\begin{array}{l}10.2 \\
(0.4)\end{array}$ & $\begin{array}{c}0.143 \\
(0.005)\end{array}$ & $\begin{array}{l}53 \\
(19)\end{array}$ & $\begin{array}{c}0.277 \\
(0.077)\end{array}$ & $<0.100$ & $\begin{array}{c}0.503 \\
(0.224)\end{array}$ \\
\hline $\begin{array}{l}\text { Chionanthus } \\
\text { pluriflorus }\end{array}$ & $\begin{array}{c}253 \\
(214)\end{array}$ & $<0.200$ & $\begin{array}{c}0.5 \\
(0.2)\end{array}$ & $\begin{array}{l}2.6 \\
(0.7)\end{array}$ & $\begin{array}{l}8.3 \\
(3.5)\end{array}$ & $\begin{array}{l}10.7 \\
(2.9)\end{array}$ & $\begin{array}{c}0.121 \\
(0.031)\end{array}$ & $\begin{array}{c}52 \\
(24)\end{array}$ & $<0.200$ & $<0.100$ & $\begin{array}{c}0.223 \\
(0.016)\end{array}$ \\
\hline $\begin{array}{l}\text { Cinnamomum } \\
\text { subavenium }\end{array}$ & $\begin{array}{l}696 \\
(640)\end{array}$ & $<0.200$ & $\begin{array}{l}1.7 \\
(0.9)\end{array}$ & $\begin{array}{l}6.2 \\
(0.6)\end{array}$ & $\begin{array}{l}7.4 \\
(1.3)\end{array}$ & $\begin{array}{l}19.3 \\
(3.1)\end{array}$ & $\begin{array}{c}0.140 \\
(0.009)\end{array}$ & $\begin{array}{c}79 \\
(29)\end{array}$ & $\begin{array}{c}0.221 \\
(0.024)\end{array}$ & $\begin{array}{l}0.107 \\
(0.012)\end{array}$ & $\begin{array}{l}1.267 \\
(1.068)\end{array}$ \\
\hline Clausena excavata & $\begin{array}{l}26 \\
(0.3)\end{array}$ & $<0.200$ & & $\begin{array}{l}3.7 \\
(0.4)\end{array}$ & $\begin{array}{l}6.1 \\
(0.3)\end{array}$ & $\begin{array}{l}32.3 \\
(2.4)\end{array}$ & $<0.090$ & $\begin{array}{c}82 \\
(3.6)\end{array}$ & $\begin{array}{l}0.209 \\
(0.004)\end{array}$ & $<0.100$ & $\begin{array}{c}0.213 \\
(0.013)\end{array}$ \\
\hline Clidemia hirta & $\begin{array}{c}229 \\
(185)\end{array}$ & $\begin{array}{l}0.330 \\
(0.130)\end{array}$ & & $\begin{array}{c}9.2 \\
(1.9)\end{array}$ & $\begin{array}{l}8.9 \\
(0.6)\end{array}$ & $\begin{array}{l}18.0 \\
(4.9)\end{array}$ & $<0.090$ & $\begin{array}{l}98 \\
(63)\end{array}$ & $\begin{array}{l}0.217 \\
(0.017)\end{array}$ & $\begin{array}{c}0.320 \\
(0.220)\end{array}$ & $\begin{array}{l}0.430 \\
(0.169)\end{array}$ \\
\hline $\begin{array}{l}\text { Combretum } \\
\text { nigrescens }\end{array}$ & $\begin{array}{l}114 \\
(15)\end{array}$ & 4.603 & $\begin{array}{l}4.7 \\
(0.5)\end{array}$ & $\begin{array}{l}2.9 \\
(0.1)\end{array}$ & $\begin{array}{l}10.2 \\
(1.9)\end{array}$ & $\begin{array}{l}11.0 \\
(1.5)\end{array}$ & $\begin{array}{c}0.203 \\
(0.103)\end{array}$ & $\begin{array}{c}52 \\
(15)\end{array}$ & $\begin{array}{c}<0.200 \\
()\end{array}$ & $\begin{array}{l}0.150 \\
(0.028)\end{array}$ & $\begin{array}{c}0.750 \\
(0.339)\end{array}$ \\
\hline Coscinium & 101 & & 1.9 & 2.2 & 23.2 & 17.4 & 0.110 & 53 & $<0.200$ & $<0.100$ & 1.080 \\
\hline
\end{tabular}




\begin{tabular}{|c|c|c|c|c|c|c|c|c|c|c|c|}
\hline blumeanum & (39) & $(0.030)$ & $(0.2)$ & $(0.4)$ & $(9.2)$ & $(5.1)$ & $(0.011)$ & (11) & & & 7 \\
\hline Dillenia excelsa & $\begin{array}{l}20 \\
(1)\end{array}$ & $\begin{array}{c}0.300 \\
(0.002)\end{array}$ & $\begin{array}{c}1.9 \\
(0.7)\end{array}$ & $\begin{array}{l}2.4 \\
(0.5)\end{array}$ & $\begin{array}{c}6.0 \\
(0.2)\end{array}$ & $\begin{array}{l}15.0 \\
(1.2)\end{array}$ & $\begin{array}{c}0.103 \\
(0.009)\end{array}$ & $\begin{array}{l}37 \\
(8)\end{array}$ & $\begin{array}{c}0.283 \\
(0.060)\end{array}$ & $<0.100$ & $<0.200$ \\
\hline $\begin{array}{c}\text { Dimocarpus } \\
\text { dentatus }\end{array}$ & $\begin{array}{c}494 \\
(475)\end{array}$ & $\begin{array}{c}0.210 \\
(0.019)\end{array}$ & $\begin{array}{l}1.0 \\
(0.4)\end{array}$ & $\begin{array}{c}2.0 \\
(0.5)\end{array}$ & $\begin{array}{c}5.2 \\
(1.5)\end{array}$ & $\begin{array}{l}8.5 \\
(1.8)\end{array}$ & $\begin{array}{c}0.099 \\
(0.008)\end{array}$ & $\begin{array}{l}25 \\
(4)\end{array}$ & $\begin{array}{c}0.237 \\
(0.037)\end{array}$ & $\begin{array}{l}.125 \\
.011)\end{array}$ & $\begin{array}{c}0.205 \\
(0.036)\end{array}$ \\
\hline $\begin{array}{c}\text { Dimorphocalyx } \\
\text { murinus }\end{array}$ & $\begin{array}{c}972 \\
(108)\end{array}$ & $\begin{array}{c}0.213 \\
(0.013)\end{array}$ & $\begin{array}{c}0.9 \\
(0.3)\end{array}$ & $\begin{array}{c}8.9 \\
(0.5)\end{array}$ & $\begin{array}{l}8.3 \\
(0.9)\end{array}$ & $\begin{array}{l}15.3 \\
(0.9)\end{array}$ & $\begin{array}{c}0.110 \\
(0.028)\end{array}$ & $\begin{array}{l}129 \\
(29)\end{array}$ & $\begin{array}{c}0.277 \\
(0.077)\end{array}$ & & $\begin{array}{c}1.793 \\
(1.105)\end{array}$ \\
\hline $\begin{array}{l}\text { Diospyros } \\
\text { durionoides }\end{array}$ & $\begin{array}{l}1187 \\
(489)\end{array}$ & $<0.200$ & $\begin{array}{c}0.5 \\
(0.1)\end{array}$ & $\begin{array}{c}6.1 \\
(3.5)\end{array}$ & $\begin{array}{c}5.0 \\
(3.0)\end{array}$ & $\begin{array}{l}11.0 \\
(2.5)\end{array}$ & $\begin{array}{c}<0.090 \\
()\end{array}$ & $\begin{array}{c}90 \\
(19)\end{array}$ & & & $\begin{array}{c}0.507 \\
(0.297)\end{array}$ \\
\hline Diospyrus elliptifolia & $\begin{array}{c}1156 \\
(27)\end{array}$ & $<0.200$ & $\begin{array}{c}0.4 \\
(0.1)\end{array}$ & $\begin{array}{r}9.9 \\
(0.7)\end{array}$ & $\begin{array}{l}5.8 \\
(0.1)\end{array}$ & $\begin{array}{l}25.0 \\
(8.7)\end{array}$ & $<0.090$ & $\begin{array}{l}107 \\
(7)\end{array}$ & & $<0.100$ & $\begin{array}{l}0.203 \\
(0.037)\end{array}$ \\
\hline $\begin{array}{c}\text { Dipterocarpus } \\
\text { applanatus }\end{array}$ & $\begin{array}{l}1156 \\
(48)\end{array}$ & $<0.200$ & $\begin{array}{c}0.4 \\
(0.9)\end{array}$ & $\begin{array}{c}9.9 \\
(1.4)\end{array}$ & $\begin{array}{c}5.8 \\
(1.1)\end{array}$ & $\begin{array}{l}25.0 \\
(4.1)\end{array}$ & $\begin{array}{c}0.133 \\
(0.009)\end{array}$ & & & $<0.100$ & $\begin{array}{c}0.232 \\
(1.466)\end{array}$ \\
\hline $\begin{array}{c}\text { Dipterocarpus } \\
\text { gracilis }\end{array}$ & $\begin{array}{l}1051 \\
(658)\end{array}$ & $\begin{array}{c}0.210 \\
(0.006)\end{array}$ & $\begin{array}{l}1.1 \\
(2.4)\end{array}$ & $\begin{array}{l}14.6 \\
(3.6)\end{array}$ & $\begin{array}{l}13.2 \\
(2.5)\end{array}$ & $\begin{array}{l}18.0 \\
(0.7)\end{array}$ & $\begin{array}{c}0.100 \\
(0.010)\end{array}$ & 25 & $\begin{array}{c}0.253 \\
(0.030)\end{array}$ & $\begin{array}{c}0.105 \\
(0.003)\end{array}$ & $\begin{array}{c}0.220 \\
(0.022)\end{array}$ \\
\hline $\begin{array}{c}\text { Dryobalanops } \\
\text { lanceolata }\end{array}$ & $\begin{array}{l}269 \\
(96)\end{array}$ & $<0.200$ & $\begin{array}{c}0.5 \\
(0.1)\end{array}$ & $\begin{array}{c}6.6 \\
(0.3)\end{array}$ & $\begin{array}{c}6.8 \\
(1.7)\end{array}$ & $\begin{array}{l}14.3 \\
(1.2)\end{array}$ & & & $\begin{array}{c}0.250 \\
(0.013)\end{array}$ & $<0.100$ & $\begin{array}{c}0.250 \\
(0.026)\end{array}$ \\
\hline $\begin{array}{l}\text { Duabanga } \\
\text { moluccana }\end{array}$ & $\begin{array}{c}28 \\
(0.9)\end{array}$ & $\begin{array}{c}0.256 \\
(0.027)\end{array}$ & $\begin{array}{c}0.4 \\
(0.1)\end{array}$ & $\begin{array}{c}1.6 \\
(0.3)\end{array}$ & $\begin{array}{c}5.1 \\
(1.8)\end{array}$ & $\begin{array}{c}9.0 \\
(1.0)\end{array}$ & (0.008) & $\begin{array}{l}24 \\
(1)\end{array}$ & $\begin{array}{c}0.267 \\
(0.015)\end{array}$ & $<0.100$ & $<0.200$ \\
\hline Durio kutejensis & $\begin{array}{l}146 \\
(52)\end{array}$ & $\begin{array}{c}0.298 \\
(0.030)\end{array}$ & $\begin{array}{c}0.3 \\
(0.01)\end{array}$ & $\begin{array}{c}6.4 \\
(1.2)\end{array}$ & $\begin{array}{c}7.2 \\
(1.0)\end{array}$ & & $\begin{array}{l}0.111 \\
(0.002)\end{array}$ & $\begin{array}{c}65 \\
(32)\end{array}$ & $<0.200$ & $\begin{array}{c}0.101 \\
(0.008)\end{array}$ & $\begin{array}{l}0.377 \\
(0.177)\end{array}$ \\
\hline $\begin{array}{l}\text { Etlingera } \\
\text { brevilabrum }\end{array}$ & $\begin{array}{l}1122 \\
(243)\end{array}$ & $\begin{array}{c}0.251 \\
(0.031)\end{array}$ & $\begin{array}{c}0.6 \\
(0.3)\end{array}$ & $\begin{array}{l}2.9 \\
(2.1)\end{array}$ & $\begin{array}{c}9.4 \\
(0.5)\end{array}$ & 11.4 & $\begin{array}{l}0.101 \\
(0.007)\end{array}$ & $\begin{array}{c}64 \\
(39)\end{array}$ & $\begin{array}{c}0.203 \\
(0.003)\end{array}$ & $<0.100$ & $\begin{array}{l}0.228 \\
(0.005)\end{array}$ \\
\hline $\begin{array}{c}\text { Euphoria } \\
\text { malaiensis }= \\
\text { Dimocarpus longan }\end{array}$ & $\begin{array}{c}1286 \\
(55)\end{array}$ & $\begin{array}{c}0.269 \\
(0.032)\end{array}$ & $\begin{array}{c}0.4 \\
(0.1)\end{array}$ & $\begin{array}{r}2.2 \\
(0.1)\end{array}$ & & $\begin{array}{l}15.0 \\
(3.3)\end{array}$ & $<0.090$ & $\begin{array}{c}73 \\
(29)\end{array}$ & $\begin{array}{c}0.277 \\
(0.004)\end{array}$ & $\begin{array}{l}0.108 \\
(0.22)\end{array}$ & $\begin{array}{c}0.222 \\
(0.004)\end{array}$ \\
\hline Eurycoma longifolia & $\begin{array}{c}388 \\
(188)\end{array}$ & $<0.200$ & $\begin{array}{c}5.2 \\
(2.6)\end{array}$ & $\begin{array}{c}6.8 \\
(1.1)\end{array}$ & $\begin{array}{l}5.1 \\
(0.7)\end{array}$ & $\begin{array}{c}8.9 \\
(1.8)\end{array}$ & $\begin{array}{c}0.127 \\
(0.0707)\end{array}$ & $\begin{array}{l}16 \\
(4)\end{array}$ & $\begin{array}{c}0.212 \\
(0.037)\end{array}$ & $<0.100$ & $\begin{array}{c}0.423 \\
(0.118)\end{array}$ \\
\hline $\begin{array}{c}\text { Eusideroxylon } \\
\text { zwageri }\end{array}$ & $\begin{array}{l}604 \\
(131)\end{array}$ & $<0.200$ & $\begin{array}{c}1.4 \\
(0.5)\end{array}$ & & $\begin{array}{l}7.4 \\
(0.6)\end{array}$ & $\begin{array}{c}35.3 \\
(11.6)\end{array}$ & $\begin{array}{l}0.132 \\
(0.08)\end{array}$ & $\begin{array}{c}94 \\
(42)\end{array}$ & $<0.200$ & $\begin{array}{c}0.247 \\
(0.123)\end{array}$ & $\begin{array}{c}0.227 \\
(0.027)\end{array}$ \\
\hline Fagraea cuspidata & $\begin{array}{l}1085 \\
(419)\end{array}$ & $\begin{array}{c}0.209 \\
(0.029)\end{array}$ & $\begin{array}{l}1.1 \\
(0.1)\end{array}$ & & $\begin{array}{l}6.4 \\
(0.8)\end{array}$ & $\begin{array}{l}23.7 \\
(3.4)\end{array}$ & $<0.090$ & $\begin{array}{c}48 \\
(23)\end{array}$ & $<0.200$ & $\begin{array}{c}0.393 \\
(0.212)\end{array}$ & $\begin{array}{c}0.243 \\
(0.043)\end{array}$ \\
\hline $\begin{array}{c}\text { Fordia } \\
\text { splendidissima }\end{array}$ & $\begin{array}{l}140 \\
(38)\end{array}$ & $<0.200$ & & & $\begin{array}{l}8.2 \\
(0.4)\end{array}$ & $\begin{array}{l}21.3 \\
(1.5)\end{array}$ & $\begin{array}{c}0.104 \\
(0.021)\end{array}$ & $\begin{array}{c}37 \\
(14)\end{array}$ & $\begin{array}{c}0.209 \\
(0.055)\end{array}$ & $<0.100$ & $\begin{array}{c}0.457 \\
(0.091)\end{array}$ \\
\hline $\begin{array}{c}\text { Goniothalamus } \\
\text { uvarioides }\end{array}$ & $\begin{array}{l}1324 \\
(361)\end{array}$ & $<0.200$ & 8 & $\begin{array}{c}2.2 \\
(1.0)\end{array}$ & $\begin{array}{c}4.6 \\
(1.1)\end{array}$ & $\begin{array}{c}9.3 \\
(1.0)\end{array}$ & $\begin{array}{c}0.121 \\
(0.004)\end{array}$ & $\begin{array}{c}39 \\
(11)\end{array}$ & $\begin{array}{c}0.201 \\
(0.043)\end{array}$ & $<0.100$ & $<0.200$ \\
\hline $\begin{array}{c}\text { Helicia } \\
\text { artocarpoides }\end{array}$ & $\begin{array}{l}406 \\
(48)\end{array}$ & $\begin{array}{c}0.290 \\
(0.034)\end{array}$ & $\begin{array}{l}0.8 \\
(0.1)\end{array}$ & $\begin{array}{c}7.4 \\
(1.3)\end{array}$ & $\begin{array}{c}5.1 \\
(0.47)\end{array}$ & $\begin{array}{c}5.8 \\
(0.65)\end{array}$ & $\begin{array}{c}0.127 \\
(0.022)\end{array}$ & $\begin{array}{c}45 \\
(12)\end{array}$ & $<0.200$ & $<0.100$ & $\begin{array}{c}0.527 \\
(0.164)\end{array}$ \\
\hline Hopea nervosa & $\begin{array}{l}1052 \\
(664)\end{array}$ & $\begin{array}{c}0.211 \\
(0.022)\end{array}$ & $\begin{array}{l}0.8 \\
(0.1)\end{array}$ & $\begin{array}{r}3.9 \\
(1.4)\end{array}$ & $\begin{array}{l}6.6 \\
(0.1)\end{array}$ & $\begin{array}{l}14.5 \\
(1.7)\end{array}$ & $\begin{array}{c}0.143 \\
(0.009)\end{array}$ & $\begin{array}{c}343 \\
(218)\end{array}$ & $\begin{array}{c}0.299 \\
(0.036)\end{array}$ & $\begin{array}{l}0.180 \\
(0.053)\end{array}$ & $\begin{array}{r}0.240 \\
(0.027)\end{array}$ \\
\hline Hopea nutans & $\begin{array}{r}1347 \\
(32)\end{array}$ & $\begin{array}{l}0.276 \\
(0.033)\end{array}$ & $\begin{array}{l}0.6 \\
(0.03)\end{array}$ & $\begin{array}{l}3.0 \\
(0.5)\end{array}$ & $\begin{array}{l}3.4 \\
(0.1)\end{array}$ & $\begin{array}{l}12.8 \\
(2.1)\end{array}$ & $\begin{array}{c}0.132 \\
(0.007)\end{array}$ & $\begin{array}{l}32 \\
(1)\end{array}$ & $\begin{array}{c}0.232 \\
(0.034)\end{array}$ & $\begin{array}{c}0.105 \\
(0.003)\end{array}$ & $\begin{array}{r}0.325 \\
(0.083)\end{array}$ \\
\hline
\end{tabular}




\begin{tabular}{|c|c|c|c|c|c|c|c|c|c|c|c|}
\hline Hopea sangal & $\begin{array}{l}1116 \\
(613)\end{array}$ & $\begin{array}{c}0.234 \\
(0.033)\end{array}$ & $\begin{array}{r}1.1 \\
(0.2)\end{array}$ & $\begin{array}{l}3.0 \\
(0.2)\end{array}$ & $\begin{array}{c}9.3 \\
(0.9)\end{array}$ & $\begin{array}{l}16.7 \\
(0.9)\end{array}$ & $<0.090$ & $\begin{array}{c}62 \\
(40)\end{array}$ & $<0.200$ & $\begin{array}{c}0.110 \\
(0.010)\end{array}$ & $\begin{array}{r}0.230 \\
(0.030)\end{array}$ \\
\hline Ixora grandifolia & $\begin{array}{l}63 \\
(43)\end{array}$ & $\begin{array}{c}0.244 \\
(0.013)\end{array}$ & $\begin{array}{c}3.7 \\
(3.0)\end{array}$ & $\begin{array}{l}1.8 \\
(0.8)\end{array}$ & $\begin{array}{l}11.4 \\
(1.1)\end{array}$ & $\begin{array}{l}9.8 \\
(0.8)\end{array}$ & $\begin{array}{c}0.133 \\
(0.009)\end{array}$ & $\begin{array}{c}81 \\
(10)\end{array}$ & $\begin{array}{c}0.283 \\
(0.083)\end{array}$ & & $\begin{array}{r}0.320 \\
(0.120)\end{array}$ \\
\hline Knema latericia & $\begin{array}{l}231 \\
(87)\end{array}$ & $<0.200$ & $\begin{array}{c}0.7 \\
(0.3)\end{array}$ & $\begin{array}{l}10.1 \\
(3.1)\end{array}$ & $\begin{array}{l}12.3 \\
(5.0)\end{array}$ & $\begin{array}{l}24.7 \\
(7.3)\end{array}$ & $<0.090$ & $\begin{array}{c}49 \\
(20)\end{array}$ & $\begin{array}{c}0.240 \\
(0.044)\end{array}$ & $\begin{array}{c}0.143 \\
(0.038)\end{array}$ & $\begin{array}{l}0.207 \\
(0.007)\end{array}$ \\
\hline $\begin{array}{l}\text { Lansium } \\
\text { domesticum }\end{array}$ & $\begin{array}{c}50 \\
(10)\end{array}$ & $\begin{array}{c}0.230 \\
(0.030)\end{array}$ & $\begin{array}{c}1.4 \\
(0.4)\end{array}$ & $\begin{array}{l}7.1 \\
(2.6)\end{array}$ & $\begin{array}{l}13.0 \\
(5.1)\end{array}$ & $\begin{array}{l}23.7 \\
(3.3)\end{array}$ & $\begin{array}{c}0.100 \\
(0.009)\end{array}$ & $\begin{array}{c}54 \\
(22)\end{array}$ & $\begin{array}{c}0.266 \\
(0.060)\end{array}$ & $<0100$ & $\begin{array}{c}0.457 \\
(0.132)\end{array}$ \\
\hline Leea indica & $\begin{array}{c}269 \\
(137)\end{array}$ & $\begin{array}{c}0.280 \\
(0.040)\end{array}$ & $\begin{array}{l}1.1 \\
(0.3)\end{array}$ & $\begin{array}{c}5.3 \\
(1.4)\end{array}$ & $\begin{array}{l}4.6 \\
(0.9)\end{array}$ & $\begin{array}{c}9.1 \\
(2.3)\end{array}$ & $\begin{array}{c}0.100 \\
(0.011)\end{array}$ & $\begin{array}{l}11 \\
(1)\end{array}$ & & $\begin{array}{l}0.107 \\
(0.007)\end{array}$ & $<0.200$ \\
\hline $\begin{array}{l}\text { Lophoetalum } \\
\text { beccarianum }\end{array}$ & $\begin{array}{l}50 \\
(7)\end{array}$ & $<0.200$ & $\begin{array}{c}1.2 \\
(0.4)\end{array}$ & $\begin{array}{c}38.3 \\
(10.3)\end{array}$ & $\begin{array}{l}3.4 \\
(0.4)\end{array}$ & $\begin{array}{l}5.4 \\
(0.4)\end{array}$ & $<0.090$ & $\begin{array}{c}88 \\
(23)\end{array}$ & & $<0.100$ & $\begin{array}{c}0.201 \\
(0.012)\end{array}$ \\
\hline Ludekia borneensis & $\begin{array}{c}21 \\
(0.7)\end{array}$ & $<0.200$ & $\begin{array}{l}1.4 \\
(0.7)\end{array}$ & $\begin{array}{l}3.2 \\
(0.6)\end{array}$ & $\begin{array}{c}6.8 \\
(1.7)\end{array}$ & $\begin{array}{l}9.8 \\
(1.1)\end{array}$ & $<0.090$ & & & $\begin{array}{c}0.104 \\
(0.004)\end{array}$ & $\begin{array}{c}0.217 \\
(0.017)\end{array}$ \\
\hline $\begin{array}{c}\text { Luvunga } \\
\text { heterophylla }\end{array}$ & $\begin{array}{l}2022 \\
(405)\end{array}$ & $\begin{array}{c}0.220 \\
(0.043)\end{array}$ & $\begin{array}{c}0.5 \\
(0.1)\end{array}$ & $\begin{array}{c}7.4 \\
(1.2)\end{array}$ & $\begin{array}{l}7.4 \\
(0.5)\end{array}$ & $\begin{array}{l}21.0 \\
(3.1)\end{array}$ & & 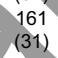 & $\begin{array}{c}0.206 \\
(0.065)\end{array}$ & $\begin{array}{c}0.187 \\
(0.009)\end{array}$ & $\begin{array}{c}0.222 \\
(0.032)\end{array}$ \\
\hline $\begin{array}{c}\text { Macaranga } \\
\text { gigantea }\end{array}$ & $\begin{array}{l}681 \\
(408)\end{array}$ & $\begin{array}{c}0.200 \\
(0.010)\end{array}$ & $\begin{array}{l}1.3 \\
(0.7)\end{array}$ & $\begin{array}{c}6.5 \\
(3.8)\end{array}$ & $\begin{array}{l}14.8 \\
(5.7)\end{array}$ & $\begin{array}{l}16.7 \\
(3.2)\end{array}$ & $\begin{array}{r}0.143 \\
(0.043)\end{array}$ & $\begin{array}{l}149 \\
(74)\end{array}$ & $\begin{array}{c}0.232 \\
(0.031)\end{array}$ & $\begin{array}{c}0.109 \\
(0.009)\end{array}$ & $\begin{array}{c}0.597 \\
(0.266)\end{array}$ \\
\hline $\begin{array}{l}\text { Macaranga } \\
\text { hypoleuca }\end{array}$ & $\begin{array}{c}312 \\
(282)\end{array}$ & $<0.200$ & $\begin{array}{c}3.9 \\
(2.0)\end{array}$ & $\begin{array}{c}4.7 \\
(1.9)\end{array}$ & $\begin{array}{l}11.0 \\
(0.3)\end{array}$ & $\begin{array}{r}13.5 \\
(1.5)\end{array}$ & & $\begin{array}{l}34 \\
(4)\end{array}$ & $<0.200$ & $\begin{array}{c}0.121 \\
(0.008)\end{array}$ & $\begin{array}{r}0.200 \\
(0.017)\end{array}$ \\
\hline Macaranga triloba & $\begin{array}{l}2032 \\
(222)\end{array}$ & $\begin{array}{c}0.236 \\
(0.011)\end{array}$ & $\begin{array}{c}2.2 \\
(1.1)\end{array}$ & $\begin{array}{l}1.6 \\
(0.4)\end{array}$ & $\begin{array}{l}10.0 \\
(0.6)\end{array}$ & $\begin{array}{l}15.0 \\
(0.9)\end{array}$ & & $\begin{array}{l}46 \\
(4)\end{array}$ & $<0.200$ & $\begin{array}{c}0.176 \\
(0.005)\end{array}$ & $\begin{array}{c}0.250 \\
(0.020)\end{array}$ \\
\hline $\begin{array}{c}\text { Macaranga } \\
\text { pearsonii }\end{array}$ & $\begin{array}{l}2631 \\
(253)\end{array}$ & $<0.200$ & $\begin{array}{l}1.6 \\
(0.1)\end{array}$ & $\begin{array}{l}3.3 \\
(0.5)\end{array}$ & $\begin{array}{l}8.9 \\
(0.7)\end{array}$ & $\begin{array}{l}17.0 \\
(0.7)\end{array}$ & $<0.090$ & $\begin{array}{c}65 \\
(21)\end{array}$ & $\begin{array}{c}0.208 \\
(0.020)\end{array}$ & $<0.100$ & $\begin{array}{c}0.335 \\
(0.063)\end{array}$ \\
\hline Madhuca korthalsii & $\begin{array}{l}221 \\
(132)\end{array}$ & $\begin{array}{c}0.246 \\
(0.011)\end{array}$ & $\begin{array}{l}11.9 \\
(5.2)\end{array}$ & $\begin{array}{l}6.0 \\
(2.5)\end{array}$ & $\begin{array}{r}8.4 \\
(0.7)\end{array}$ & $\begin{array}{c}7.5 \\
(0.2)\end{array}$ & $<0.090$ & $\begin{array}{l}40 \\
(11)\end{array}$ & $\begin{array}{c}0.233 \\
(0.033)\end{array}$ & $\begin{array}{c}0.154 \\
(0.006)\end{array}$ & $\begin{array}{r}0.450 \\
(0.131)\end{array}$ \\
\hline $\begin{array}{c}\text { Mallotus } \\
\text { mollissimus }\end{array}$ & $\begin{array}{l}434 \\
(335)\end{array}$ & $\begin{array}{c}0.263 \\
(0.054)\end{array}$ & $\begin{array}{l}1.5 \\
(0.2)\end{array}$ & $\begin{array}{l}5.5 \\
(0.8)\end{array}$ & $\begin{array}{l}5.3 \\
(0.7)\end{array}$ & $\begin{array}{l}16.0 \\
(1.7)\end{array}$ & $\begin{array}{c}0.117 \\
(0.028)\end{array}$ & $\begin{array}{l}117 \\
(28)\end{array}$ & $\begin{array}{c}0.237 \\
(0.037)\end{array}$ & $<0.100$ & $\begin{array}{c}0.205 \\
(0.011)\end{array}$ \\
\hline Mallotus wrayi & $\begin{array}{c}2565 \\
(53)\end{array}$ & $\begin{array}{c}0.300 \\
(0.031)\end{array}$ & $\begin{array}{c}0.9 \\
(0.2)\end{array}$ & $\begin{array}{c}1.3 \\
(0.2)\end{array}$ & $\begin{array}{r}7.0 \\
(1.0)\end{array}$ & $\begin{array}{l}17.0 \\
(1.5)\end{array}$ & $\begin{array}{c}0.107 \\
(0.027)\end{array}$ & $\begin{array}{l}62 \\
(5)\end{array}$ & $\begin{array}{c}0.243 \\
(0.031)\end{array}$ & $<0.100$ & $\begin{array}{c}0.207 \\
(0.007)\end{array}$ \\
\hline $\begin{array}{c}\text { Melastoma } \\
\text { malabathricum }\end{array}$ & $\begin{array}{l}646 \\
(275)\end{array}$ & $\begin{array}{c}0.220 \\
(0.029)\end{array}$ & $\begin{array}{c}0.7 \\
(0.3)\end{array}$ & $\begin{array}{l}7.3 \\
(3.6)\end{array}$ & $\begin{array}{l}7.5 \\
(2.1)\end{array}$ & $\begin{array}{l}11.8 \\
(3.6)\end{array}$ & $\begin{array}{c}0.143 \\
(0.023)\end{array}$ & $\begin{array}{l}251 \\
(43)\end{array}$ & $\begin{array}{c}0.208 \\
(0.021)\end{array}$ & $\begin{array}{c}0.118 \\
(0.008)\end{array}$ & $\begin{array}{c}0.235 \\
(0.040)\end{array}$ \\
\hline $\begin{array}{l}\text { Memecylon } \\
\text { laevigatum }\end{array}$ & $\begin{array}{l}55 \\
(4)\end{array}$ & $\begin{array}{c}0.263 \\
(0.011)\end{array}$ & $\begin{array}{c}1.3 \\
(0.4)\end{array}$ & $\begin{array}{l}2.9 \\
(0.2)\end{array}$ & $\begin{array}{l}5.2 \\
(0.5)\end{array}$ & $\begin{array}{c}6.9 \\
(1.0)\end{array}$ & $<0.090$ & $\begin{array}{l}115 \\
(18)\end{array}$ & $<0.200$ & $\begin{array}{c}0.109 \\
(0.010)\end{array}$ & $<0.200$ \\
\hline $\begin{array}{c}\text { Neonauclea } \\
\text { artocarpioides }\end{array}$ & $\begin{array}{c}73 \\
(30)\end{array}$ & $\begin{array}{c}0.250 \\
(0.025)\end{array}$ & $\begin{array}{l}1.9 \\
(0.4)\end{array}$ & $\begin{array}{l}6.9 \\
(2.6)\end{array}$ & $\begin{array}{l}6.0 \\
(0.6)\end{array}$ & $\begin{array}{l}13.0 \\
(0.6)\end{array}$ & $\begin{array}{c}0.153 \\
(0.053)\end{array}$ & $\begin{array}{c}65 \\
(19)\end{array}$ & $<0.200$ & $<0.100$ & $\begin{array}{c}0.430 \\
(0.125)\end{array}$ \\
\hline $\begin{array}{l}\text { Nephelium } \\
\text { ramboutan-ake }\end{array}$ & $\begin{array}{c}62 \\
(24)\end{array}$ & $<0.200$ & 1.0 & $\begin{array}{l}3.1 \\
(0.8)\end{array}$ & $\begin{array}{c}9.4 \\
(2.1)\end{array}$ & $\begin{array}{l}18.7 \\
(3.0)\end{array}$ & $<0.090$ & $\begin{array}{c}57 \\
(18)\end{array}$ & $\begin{array}{c}0.244 \\
(0.023)\end{array}$ & $\begin{array}{l}<0.100 \\
()\end{array}$ & $\begin{array}{c}0.233 \\
(0.033)\end{array}$ \\
\hline $\begin{array}{c}\text { Ochanostachys } \\
\text { amentacea }\end{array}$ & $\begin{array}{l}224 \\
(26)\end{array}$ & & & $\begin{array}{c}1.3 \\
(0.5)\end{array}$ & $\begin{array}{l}7.8 \\
(0.8)\end{array}$ & $\begin{array}{c}10.8 \\
(1.11)\end{array}$ & $<0.090$ & $\begin{array}{c}26 \\
(3.5)\end{array}$ & $\begin{array}{c}0.255 \\
(0.005)\end{array}$ & $\begin{array}{c}0.103 \\
(0.020)\end{array}$ & $\begin{array}{c}0.307 \\
(0.107)\end{array}$ \\
\hline $\begin{array}{l}\text { Octomeles } \\
\text { sumatrana }\end{array}$ & $\begin{array}{l}1203 \\
(386)\end{array}$ & & $\begin{array}{l}0.3 \\
(0.1)\end{array}$ & $\begin{array}{c}3.7 \\
(1.1)\end{array}$ & $\begin{array}{c}6.0 \\
(0.6)\end{array}$ & $\begin{array}{l}17.7 \\
(1.2)\end{array}$ & $\begin{array}{c}0.123 \\
(0.010)\end{array}$ & $\begin{array}{l}110 \\
(54)\end{array}$ & $\begin{array}{c}0.243 \\
(0.043)\end{array}$ & $\begin{array}{c}0.103 \\
(0.003)\end{array}$ & $<0.200$ \\
\hline
\end{tabular}




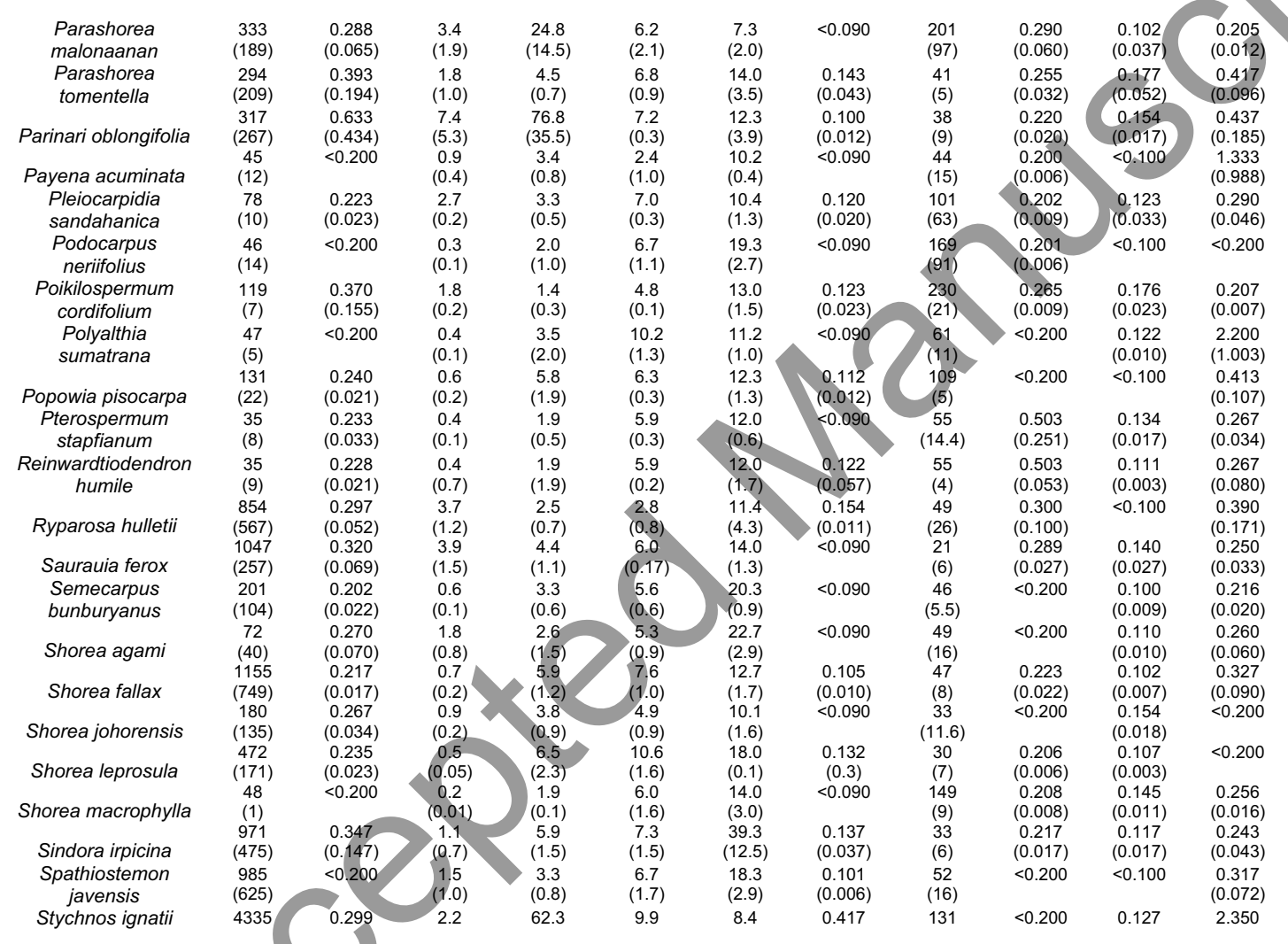




\begin{tabular}{|c|c|c|c|c|c|c|c|c|c|c|c|}
\hline & (648) & $(0.028)$ & $(1.0)$ & $(31.5)$ & (1.1) & (1.5) & $(0.166)$ & (63) & () & $(0.027)$ & $(0$. \\
\hline $\begin{array}{c}\text { Syzygium } \\
\text { campanulatum }\end{array}$ & $\begin{array}{c}47 \\
(27)\end{array}$ & $\begin{array}{c}0.222 \\
(0.012)\end{array}$ & $\begin{array}{c}0.7 \\
(0.2)\end{array}$ & $\begin{array}{l}3.0 \\
(0.6)\end{array}$ & $\begin{array}{l}7.0 \\
(2.9)\end{array}$ & $\begin{array}{l}20.8 \\
(1.2)\end{array}$ & $\begin{array}{c}0.122 \\
(0.011)\end{array}$ & $\begin{array}{l}18 \\
(1)\end{array}$ & $<0.200$ & $<0.100$ & $\begin{array}{c}0.800 \\
(0.601)\end{array}$ \\
\hline $\begin{array}{l}\text { Tarbernaemontana } \\
\text { macrocarpa }\end{array}$ & $\begin{array}{l}1510 \\
(241)\end{array}$ & $\begin{array}{c}0.287 \\
(0.011)\end{array}$ & $\begin{array}{c}0.5 \\
(0.1)\end{array}$ & $\begin{array}{c}3.9 \\
(1.4)\end{array}$ & $\begin{array}{l}15.3 \\
(2.9)\end{array}$ & $\begin{array}{l}31.7 \\
(1.2)\end{array}$ & $\begin{array}{c}0.109 \\
(0.007)\end{array}$ & $\begin{array}{l}21 \\
(1)\end{array}$ & $<0.200$ & & $\begin{array}{c}0.933 \\
(0.734)\end{array}$ \\
\hline Uncaria cordata & $\begin{array}{c}1243 \\
(1141)\end{array}$ & $<0.200$ & $\begin{array}{c}3.6 \\
(2.8)\end{array}$ & $\begin{array}{l}2.2 \\
(0.3)\end{array}$ & $\begin{array}{c}7.2 \\
(0.7)\end{array}$ & $\begin{array}{c}35.3 \\
(18.0)\end{array}$ & $<0.090$ & $\begin{array}{l}24 \\
(4)\end{array}$ & $\begin{array}{r}0.267 \\
(0.040)\end{array}$ & $\begin{array}{l}0.123 \\
(0.023)\end{array}$ & $\begin{array}{c}0.200 \\
(0.005)\end{array}$ \\
\hline Urophyllum glabrum & $\begin{array}{c}1243 \\
(43)\end{array}$ & $\begin{array}{c}0.202 \\
(0.013)\end{array}$ & $\begin{array}{c}3.6 \\
(6.2)\end{array}$ & $\begin{array}{l}2.2 \\
(1.5)\end{array}$ & $\begin{array}{l}7.2 \\
(0.7)\end{array}$ & $\begin{array}{l}35.3 \\
(2.3)\end{array}$ & $\begin{array}{c}0.122 \\
(0.097)\end{array}$ & $\begin{array}{c}24 \\
(31)\end{array}$ & $\begin{array}{l}0.223 \\
(0.012)\end{array}$ & $\begin{array}{l}0.123 \\
(0.033)\end{array}$ & $\begin{array}{c}0.213 \\
(0.067)\end{array}$ \\
\hline $\begin{array}{c}\text { Uvaria } \\
\text { sorzogonensis }\end{array}$ & $\begin{array}{c}867 \\
(234)\end{array}$ & $<0.200$ & $\begin{array}{c}0.8 \\
(0.1)\end{array}$ & $\begin{array}{c}8.6 \\
(1.2)\end{array}$ & $\begin{array}{l}7.8 \\
(0.6)\end{array}$ & $\begin{array}{l}12.0 \\
(0.6)\end{array}$ & $\begin{array}{c}0.130 \\
(0.010)\end{array}$ & & $<0.200$ & $\begin{array}{l}0.107 \\
(0.006)\end{array}$ & $\begin{array}{c}0.260 \\
(0.060)\end{array}$ \\
\hline $\begin{array}{l}\text { Xanthophyllum } \\
\text { affine }\end{array}$ & $\begin{array}{l}121 \\
(48)\end{array}$ & $\begin{array}{c}0.260 \\
(0.009)\end{array}$ & $\begin{array}{c}0.4 \\
(0.1)\end{array}$ & $\begin{array}{l}11.9 \\
(5.7)\end{array}$ & $\begin{array}{c}8.3 \\
(2.2)\end{array}$ & $\begin{array}{l}14.3 \\
(0.9)\end{array}$ & $<0.090$ & & $\begin{array}{l}0.222 \\
(0.013)\end{array}$ & $\begin{array}{c}0.124 \\
(0.008)\end{array}$ & $\begin{array}{c}0.900 \\
(0.701)\end{array}$ \\
\hline $\begin{array}{c}\text { Zizyphus } \\
\text { angustifolius }\end{array}$ & $\begin{array}{l}1042 \\
(542)\end{array}$ & $<0.200$ & $\begin{array}{c}9.5 \\
(9.3)\end{array}$ & $\begin{array}{c}8.3 \\
(3.6)\end{array}$ & $\begin{array}{c}5.4 \\
(1.6)\end{array}$ & $\begin{array}{l}17.0 \\
(2.6)\end{array}$ & 990 & & $<0.200$ & $\begin{array}{c}0.137 \\
(0.037)\end{array}$ & $\begin{array}{c}0.220 \\
(0.020)\end{array}$ \\
\hline
\end{tabular}


Table S4. Foliar concentrations of phenolics and tannins, and morphological foliar traits (Mean, S.E between brackets) of 88 common rainforest plant species in Danum Valley (Borneo). LMA = Leaf mass area. $\mathrm{L}=$ Length. $\mathrm{R}=$ Roundness. $\mathrm{COM}=$ Compactness. $\mathrm{P} / \mathrm{a}=$ leaf perimeter/leaf area. $\mathrm{F}=$ Accumulated standing folivory (\% of leaf lost) $(\mathrm{n}=3$ for chemical analyses and $\mathrm{n}=6-37$ for morphological and folivory variables).

\begin{tabular}{|c|c|c|c|c|c|c|c|c|c|c|c|c|}
\hline Species & $\begin{array}{l}\text { Phenolics } \\
\text { mg g }^{-1}\end{array}$ & $\begin{array}{l}\text { Tannins } \\
\mathrm{mg} \mathrm{g}^{-1}\end{array}$ & $\begin{array}{l}\text { Leaf } \\
\text { area } \\
\left(\mathrm{cm}^{2}\right)\end{array}$ & $\begin{array}{c}\text { Leaf } \\
\text { dry } \\
\text { weight } \\
\text { (g) }\end{array}$ & $\begin{array}{l}\text { Leaf } \\
\text { dry/fresh } \\
\text { weight } \\
\text { ratio }\end{array}$ & $\begin{array}{c}\text { LMA } \\
\text { (Dry } \\
\text { weight) }\end{array}$ & $\begin{array}{c}\text { LMA } \\
\text { (Fresh } \\
\text { weight) }\end{array}$ & L & & & & $\mathbf{F}$ \\
\hline Agelaea borneensis & $\begin{array}{l}2.41 \\
(0.75)\end{array}$ & $\begin{array}{c}1.49 \\
(0.42)\end{array}$ & $\begin{array}{l}84.7 \\
(4.8)\end{array}$ & $\begin{array}{c}0.415 \\
(0.027)\end{array}$ & $\begin{array}{c}0.332 \\
(0.008)\end{array}$ & $\begin{array}{l}48.7 \\
(1.4)\end{array}$ & $\begin{array}{l}146 \\
(2)\end{array}$ & $\begin{array}{c}2.335 \\
(0.048)\end{array}$ & $\begin{array}{c}0.623 \\
(0.010)\end{array}$ & $\begin{array}{l}0.621 \\
(0.008)\end{array}$ & $\begin{array}{l}52.4 \\
(1.8)\end{array}$ & $\begin{array}{l}0.053 \\
(0.009)\end{array}$ \\
\hline Alangium javanicum & $\begin{array}{l}17.1 \\
(0.00)\end{array}$ & 16.1 & $\begin{array}{l}128 \\
7()\end{array}$ & $\begin{array}{l}0.633 \\
(0.034)\end{array}$ & $\begin{array}{c}0.304 \\
(0.004)\end{array}$ & $\begin{array}{l}49.9 \\
(1.0)\end{array}$ & $\begin{array}{l}163 \\
(2)\end{array}$ & $\begin{array}{l}2.768 \\
(0.060)\end{array}$ & $\begin{array}{c}0.563 \\
(0.011)\end{array}$ & $\begin{array}{c}0.572 \\
(0.008)\end{array}$ & $\begin{array}{l}82.6 \\
(3.1)\end{array}$ & $\begin{array}{c}0.055 \\
(0.011)\end{array}$ \\
\hline Ardisia elliptica & $\begin{array}{l}21.5 \\
(5.5)\end{array}$ & $\begin{array}{c}13.1 \\
(3.74)\end{array}$ & $\begin{array}{l}80.1 \\
(4.8)\end{array}$ & $\begin{array}{l}0.717 \\
(0.043)\end{array}$ & $\begin{array}{c}0.277 \\
(0.005)\end{array}$ & $\begin{array}{l}90.1 \\
(1.9)\end{array}$ & $\begin{array}{l}325 \\
(3)\end{array}$ & $\begin{array}{l}2.950 \\
(0.533)\end{array}$ & $\begin{array}{l}0.533 \\
(0.008)\end{array}$ & $\begin{array}{c}0.552 \\
(0.007)\end{array}$ & $\begin{array}{l}19.5 \\
(0.7)\end{array}$ & $\begin{array}{l}0.025 \\
(0.006)\end{array}$ \\
\hline $\begin{array}{l}\text { Artocarpus } \\
\text { anisophyllus }\end{array}$ & $\begin{array}{l}20.3 \\
(5.4)\end{array}$ & $\begin{array}{c}14.8 \\
(0.448)\end{array}$ & $\begin{array}{l}3222 \\
(263)\end{array}$ & $\begin{array}{l}45.7 \\
(2.4)\end{array}$ & $\begin{array}{c}0.437 \\
(0.028)\end{array}$ & $\begin{array}{l}155.5 \\
(15.8)\end{array}$ & $\begin{array}{l}349 \\
(17)\end{array}$ & $\begin{array}{l}1.556 \\
(0.058)\end{array}$ & $\begin{array}{l}0.058 \\
(0.006)\end{array}$ & $\begin{array}{c}0.641 \\
(0.021)\end{array}$ & $\begin{array}{l}25.1 \\
(3.0)\end{array}$ & $\begin{array}{c}0.060 \\
(0.030)\end{array}$ \\
\hline $\begin{array}{l}\text { Baccaurea } \\
\text { lanceolata }\end{array}$ & $\begin{array}{l}11.5 \\
(3.6)\end{array}$ & $\begin{array}{l}4.19 \\
(1.24)\end{array}$ & $\begin{array}{l}250 \\
(16)\end{array}$ & $\begin{array}{c}1.60 \\
(0.12)\end{array}$ & $\begin{array}{c}0.277 \\
(0.004)\end{array}$ & & & $\begin{array}{l}2.285 \\
(0.625)\end{array}$ & $\begin{array}{l}0.625 \\
(0.007)\end{array}$ & $\begin{array}{c}0.641 \\
(0.008)\end{array}$ & $\begin{array}{l}42.9 \\
(1.2)\end{array}$ & $\begin{array}{c}0.076 \\
(0.009)\end{array}$ \\
\hline $\begin{array}{l}\text { Baccaurea } \\
\text { macrocarpa }\end{array}$ & $\begin{array}{l}10.9 \\
(2.3)\end{array}$ & $\begin{array}{l}5.98 \\
(1.88)\end{array}$ & $\begin{array}{l}245 \\
(12)\end{array}$ & $\begin{array}{l}3.30 \\
(0.18)\end{array}$ & $\begin{array}{c}0.389 \\
(0.008)\end{array}$ & $\begin{array}{l}137.7 \\
(5.6)\end{array}$ & & $\begin{array}{l}2.001 \\
(0.678)\end{array}$ & $\begin{array}{l}0.678 \\
(0.005)\end{array}$ & $\begin{array}{c}0.681 \\
(0.004)\end{array}$ & $\begin{array}{l}53.4 \\
(2.1)\end{array}$ & $\begin{array}{c}0.040 \\
(0.010)\end{array}$ \\
\hline $\begin{array}{l}\text { Barringtonia } \\
\text { sarcostachys }\end{array}$ & $\begin{array}{l}23.5 \\
(7.6)\end{array}$ & $\begin{array}{c}1.956 \\
(0.635)\end{array}$ & $\begin{array}{l}554 \\
(44)\end{array}$ & $\begin{array}{l}7.77 \\
(0.83)\end{array}$ & $\begin{array}{l}0.316 \\
(0.010)\end{array}$ & $\begin{array}{c}136.0 \\
(6.4)\end{array}$ & $\begin{array}{l}427 \\
(13)\end{array}$ & $\begin{array}{c}3.812 \\
(0.374)\end{array}$ & $\begin{array}{l}0.374 \\
(0.008)\end{array}$ & $\begin{array}{c}0.455 \\
(0.007)\end{array}$ & $\begin{array}{l}186 \\
(10)\end{array}$ & $\begin{array}{c}0.051 \\
(0.014)\end{array}$ \\
\hline $\begin{array}{c}\text { Blumeodendron } \\
\text { tokbrai }\end{array}$ & $\begin{array}{l}23.3 \\
(7.6)\end{array}$ & $\begin{array}{c}1.14 \\
(0.325)\end{array}$ & $\begin{array}{l}300 \\
(19)\end{array}$ & $\begin{array}{c}2.80 \\
(0.18)\end{array}$ & $\begin{array}{c}0.450 \\
(0.006)\end{array}$ & $\begin{array}{l}92.8 \\
(2.0)\end{array}$ & $\begin{array}{c}206 \\
(3)\end{array}$ & $\begin{array}{l}1.838 \\
(0.715)\end{array}$ & $\begin{array}{l}0.715 \\
(0.007)\end{array}$ & $\begin{array}{c}0.701 \\
(0.009)\end{array}$ & $\begin{array}{l}38.4 \\
(0.9)\end{array}$ & $\begin{array}{c}0.035 \\
(0.007)\end{array}$ \\
\hline Brownlowia peltata & $\begin{array}{l}87.0 \\
(17.0)\end{array}$ & $\begin{array}{l}24.1 \\
(4.8)\end{array}$ & $\begin{array}{l}478 \\
(34)\end{array}$ & $\begin{array}{c}3.07 \\
(0.25)\end{array}$ & $\begin{array}{l}0.383 \\
(0.007)\end{array}$ & $\begin{array}{l}63.2 \\
(1.6)\end{array}$ & $\begin{array}{l}166 \\
(4)\end{array}$ & $\begin{array}{l}1.394 \\
(0.744)\end{array}$ & $\begin{array}{c}0.744 \\
(0.010)\end{array}$ & $\begin{array}{c}0.822 \\
(0.010)\end{array}$ & $\begin{array}{l}7.67 \\
(0.7)\end{array}$ & $\begin{array}{l}0.091 \\
(0.013)\end{array}$ \\
\hline Caesalpinia major & $\begin{array}{l}33.4 \\
(10.7)\end{array}$ & $\begin{array}{l}4.87 \\
(1.69)\end{array}$ & $\begin{array}{l}80.7 \\
(4.2)\end{array}$ & $\begin{array}{c}0.640 \\
(0.039)\end{array}$ & $\begin{array}{r}0.332 \\
(0.006)\end{array}$ & $\begin{array}{l}78.8 \\
(2.1)\end{array}$ & $\begin{array}{l}237 \\
(3)\end{array}$ & $\begin{array}{l}1.704 \\
(0.106)\end{array}$ & $\begin{array}{l}0.106 \\
(0.007)\end{array}$ & $\begin{array}{c}0.657 \\
(0.007)\end{array}$ & $\begin{array}{l}48.6 \\
(4.2)\end{array}$ & $\begin{array}{l}0.079 \\
(0.022)\end{array}$ \\
\hline Callicarpa longifolia & $\begin{array}{l}16.6 \\
(15.5)\end{array}$ & $\begin{array}{l}4.27 \\
(3.78)\end{array}$ & $\begin{array}{l}45.0 \\
(2.4)\end{array}$ & $\begin{array}{c}0.196 \\
(0.010)\end{array}$ & $\begin{array}{l}0.364 \\
(0.007)\end{array}$ & $\begin{array}{l}44.0 \\
(0.6)\end{array}$ & $\begin{array}{l}122 \\
(2)\end{array}$ & $\begin{array}{c}2.434 \\
(0.546)\end{array}$ & $\begin{array}{l}0.546 \\
(0.012)\end{array}$ & $\begin{array}{l}0.577 \\
(0.009)\end{array}$ & $\begin{array}{l}25.0 \\
(1.7)\end{array}$ & $\begin{array}{c}0.086 \\
(0.016)\end{array}$ \\
\hline $\begin{array}{c}\text { Canarium } \\
\text { denticulatum }\end{array}$ & $\begin{array}{l}20.5 \\
(3.2)\end{array}$ & $\begin{array}{c}5.17 \\
(0.87)\end{array}$ & $\begin{array}{l}109 \\
(7)\end{array}$ & $\begin{array}{l}0.528 \\
(0.029)\end{array}$ & $\begin{array}{l}0.382 \\
(0.008)\end{array}$ & $\begin{array}{l}50.4 \\
(1.2)\end{array}$ & $\begin{array}{l}132 \\
(1)\end{array}$ & $\begin{array}{l}2.577 \\
(0.536)\end{array}$ & $\begin{array}{l}0.536 \\
(0.009)\end{array}$ & $\begin{array}{c}0.596 \\
(0.009)\end{array}$ & $\begin{array}{l}22.8 \\
(1.3)\end{array}$ & $\begin{array}{c}0.066 \\
(0.012)\end{array}$ \\
\hline $\begin{array}{l}\text { Chionanthus } \\
\text { pluriflorus }\end{array}$ & $\begin{array}{l}11.4 \\
(2.9)\end{array}$ & $\begin{array}{c}7.07 \\
(1.21)\end{array}$ & $\begin{array}{l}142 \\
(5)\end{array}$ & $\begin{array}{l}0.917 \\
(0.038)\end{array}$ & $\begin{array}{c}0.388 \\
(0.005)\end{array}$ & $\begin{array}{l}64.8 \\
(1.3)\end{array}$ & $\begin{array}{l}166 \\
(2)\end{array}$ & $\begin{array}{l}2.763 \\
(0.584)\end{array}$ & $\begin{array}{l}0.584 \\
(0.008)\end{array}$ & $\begin{array}{c}0.580 \\
(0.005)\end{array}$ & $\begin{array}{l}22.9 \\
(0.6)\end{array}$ & $\begin{array}{c}0.043 \\
(0.007)\end{array}$ \\
\hline $\begin{array}{l}\text { Cinnamomum } \\
\text { subavenium }\end{array}$ & $\begin{array}{c}2.7 \\
(0.09)\end{array}$ & $\begin{array}{l}1.34 \\
(0.04)\end{array}$ & $\begin{array}{l}72.0 \\
(3.9)\end{array}$ & $\begin{array}{l}0.461 \\
(0.019)\end{array}$ & $\begin{array}{c}0.385 \\
(0.005)\end{array}$ & $\begin{array}{l}67.4 \\
(1.3)\end{array}$ & $\begin{array}{l}174 \\
(2)\end{array}$ & $\begin{array}{c}3.629 \\
(0.479)\end{array}$ & $\begin{array}{c}0.479 \\
(0.013)\end{array}$ & $\begin{array}{l}0.504 \\
(0.009)\end{array}$ & $\begin{array}{l}65.6 \\
(1.5)\end{array}$ & $\begin{array}{c}0.049 \\
(0.009)\end{array}$ \\
\hline Clausena excavata & $\begin{array}{l}6.8 \\
(4.3)\end{array}$ & $\begin{array}{l}4.10 \\
(0.30)\end{array}$ & $\begin{array}{l}20.0 \\
(0.7)\end{array}$ & $\begin{array}{c}0.112 \\
(0.006)\end{array}$ & $\begin{array}{c}0.361 \\
(0.004)\end{array}$ & $\begin{array}{l}55.5 \\
(1.2)\end{array}$ & $\begin{array}{c}154 \\
(3)\end{array}$ & $\begin{array}{c}2.845 \\
(0.502)\end{array}$ & $\begin{array}{c}0.502 \\
(0.005)\end{array}$ & $\begin{array}{c}0.545 \\
(0.004)\end{array}$ & $\begin{array}{l}31.1 \\
(0.5)\end{array}$ & $\begin{array}{c}0.012 \\
(0.002)\end{array}$ \\
\hline Clidemia hirta & 35.6 & 4.94 & 64.7 & 0.275 & 0.340 & 43.2 & 128 & 1.974 & 0.599 & 0.663 & 24.3 & 0.027 \\
\hline
\end{tabular}




\begin{tabular}{|c|c|c|c|c|c|c|c|c|c|c|c|c|}
\hline & $(12.7)$ & $(1.96)$ & $(2.0)$ & $(0.012)$ & $(0.006)$ & $(1.6)$ & (5) & $(0.599)$ & $(0.006)$ & $(0.005)$ & $(0.4)$ & 05 \\
\hline $\begin{array}{l}\text { Combretum } \\
\text { nigrescens }\end{array}$ & $\begin{array}{c}38.9 \\
(12.7)\end{array}$ & $\begin{array}{l}1.87 \\
(0.49)\end{array}$ & $\begin{array}{l}34.6 \\
(1.8)\end{array}$ & $\begin{array}{c}0.169 \\
(0.008)\end{array}$ & $\begin{array}{c}0.423 \\
(0.004)\end{array}$ & $\begin{array}{l}50.3 \\
(1.5)\end{array}$ & $\begin{array}{l}118 \\
(3)\end{array}$ & $\begin{array}{l}2.525 \\
(0.596)\end{array}$ & $\begin{array}{c}0.596 \\
(0.010)\end{array}$ & $\begin{array}{c}0.600 \\
(0.008)\end{array}$ & $\begin{array}{l}38.2 \\
(1.3)\end{array}$ & $\begin{array}{r}0.049 \\
(0.011)\end{array}$ \\
\hline $\begin{array}{c}\text { Coscinium } \\
\text { blumeanum }\end{array}$ & $\begin{array}{l}3.0 \\
(3.0)\end{array}$ & $\begin{array}{c}2.82 \\
(2.17)\end{array}$ & $\begin{array}{l}303 \\
(18)\end{array}$ & $\begin{array}{c}1.63 \\
(0.15)\end{array}$ & $\begin{array}{c}0.425 \\
(0.012)\end{array}$ & $\begin{array}{l}54.2 \\
(3.1)\end{array}$ & $\begin{array}{l}126 \\
(6)\end{array}$ & $\begin{array}{c}1.280 \\
(0.721)\end{array}$ & $\begin{array}{c}0.721 \\
(0.010)\end{array}$ & $\begin{array}{c}0.833 \\
(0.010)\end{array}$ & $\begin{array}{l}32.0 \\
(0.5)\end{array}$ & $\begin{array}{c}0.020 \\
(0.007)\end{array}$ \\
\hline Dillenia excelsa & $\begin{array}{l}32.3 \\
(8.2)\end{array}$ & $\begin{array}{c}4.16 \\
(1.09)\end{array}$ & $\begin{array}{c}215 \\
(9)\end{array}$ & $\begin{array}{c}2.95 \\
(0.15)\end{array}$ & $\begin{array}{c}0.339 \\
(0.006)\end{array}$ & $\begin{array}{l}138.8 \\
(3.7)\end{array}$ & $\begin{array}{r}407 \\
(6)\end{array}$ & $\begin{array}{l}1.806 \\
(0.705)\end{array}$ & $\begin{array}{c}0.705 \\
(0.006)\end{array}$ & $\begin{array}{c}0.728 \\
(0.006)\end{array}$ & $\begin{array}{l}81.3 \\
(2.0)\end{array}$ & $\begin{array}{c}0.018 \\
(0.005)\end{array}$ \\
\hline $\begin{array}{c}\text { Dimocarpus } \\
\text { dentatus }\end{array}$ & $\begin{array}{l}15.0 \\
(4.8)\end{array}$ & $\begin{array}{l}5.25 \\
(2.40)\end{array}$ & $\begin{array}{l}134 \\
(4)\end{array}$ & $\begin{array}{c}0.458 \\
(0.015)\end{array}$ & $\begin{array}{c}0.362 \\
(0.005)\end{array}$ & $\begin{array}{l}34.3 \\
(0.6)\end{array}$ & $\begin{array}{l}94.4 \\
(0.9)\end{array}$ & $\begin{array}{l}2.654 \\
(0.436)\end{array}$ & $\begin{array}{l}0.436 \\
(0.007)\end{array}$ & $\begin{array}{l}0.577 \\
(0.005)\end{array}$ & $\begin{array}{l}16.1 \\
(0.4)\end{array}$ & $\begin{array}{c}0.031 \\
(0.004)\end{array}$ \\
\hline $\begin{array}{c}\text { Dimorphocalyx } \\
\text { murinus }\end{array}$ & $\begin{array}{c}1.2 \\
(0.5)\end{array}$ & $\begin{array}{c}0.977 \\
(0.340)\end{array}$ & $\begin{array}{l}184 \\
(13)\end{array}$ & $\begin{array}{c}1.11 \\
(0.09)\end{array}$ & $\begin{array}{c}0.276 \\
(0.006)\end{array}$ & $\begin{array}{l}61.6 \\
(1.9)\end{array}$ & $\begin{array}{l}221 \\
(3)\end{array}$ & $\begin{array}{c}2.439 \\
(0.584)\end{array}$ & $\begin{array}{l}0.584 \\
(0.009)\end{array}$ & $\begin{array}{l}0.610 \\
(0.008)\end{array}$ & $\begin{array}{l}94.5 \\
(0.7)\end{array}$ & $\begin{array}{c}0.063 \\
(0.013)\end{array}$ \\
\hline $\begin{array}{c}\text { Diospyros } \\
\text { durionoides }\end{array}$ & $\begin{array}{l}23.8 \\
(7.3)\end{array}$ & $\begin{array}{c}6.99 \\
(2.05)\end{array}$ & $\begin{array}{l}110 \\
(8)\end{array}$ & $\begin{array}{c}1.68 \\
(0.14)\end{array}$ & $\begin{array}{c}0.474 \\
(0.009)\end{array}$ & $\begin{array}{l}155.6 \\
(5.1)\end{array}$ & $\begin{array}{l}323 \\
(6)\end{array}$ & $\begin{array}{l}3.338 \\
(0.521)\end{array}$ & $\begin{array}{l}0.521 \\
(0.007)\end{array}$ & $\begin{array}{l}0.549 \\
(0.005)\end{array}$ & $\begin{array}{c}44.5 \\
()\end{array}$ & $\begin{array}{c}0.083 \\
(0.020)\end{array}$ \\
\hline Diospyrus elliptifolia & $\begin{array}{c}1.4 \\
(0.4)\end{array}$ & $\begin{array}{c}1.24 \\
(0.35)\end{array}$ & $\begin{array}{c}109 \\
(5)\end{array}$ & $\begin{array}{c}0.782 \\
(0.037)\end{array}$ & $\begin{array}{c}0.338 \\
(0.004)\end{array}$ & $\begin{array}{l}72.2 \\
(1.3)\end{array}$ & $\begin{array}{c}213 \\
(3)\end{array}$ & $\begin{array}{l}1.905 \\
(0.694)\end{array}$ & $\begin{array}{c}0.694 \\
(0.009)\end{array}$ & $\begin{array}{c}0.699 \\
(0.007)\end{array}$ & $\begin{array}{l}35.8 \\
(1.0)\end{array}$ & $\begin{array}{c}0.060 \\
(0.014)\end{array}$ \\
\hline $\begin{array}{c}\text { Dipterocarpus } \\
\text { applanatus }\end{array}$ & $\begin{array}{l}17.4 \\
(8.0)\end{array}$ & $\begin{array}{c}2.63 \\
(1.21)\end{array}$ & $\begin{array}{l}842 \\
(43)\end{array}$ & $\begin{array}{l}11.7 \\
(0.6)\end{array}$ & $\begin{array}{c}0.427 \\
(0.006)\end{array}$ & $\begin{array}{l}142.3 \\
(4.1)\end{array}$ & 332 & $\begin{array}{l}2.141 \\
(0.640)\end{array}$ & $\begin{array}{c}0.640 \\
(0.008)\end{array}$ & $\begin{array}{c}0.667 \\
(0.006)\end{array}$ & $\begin{array}{l}93.4 \\
(6.5)\end{array}$ & $\begin{array}{c}0.041 \\
(0.009)\end{array}$ \\
\hline $\begin{array}{l}\text { Dipterocarpus } \\
\text { gracilis }\end{array}$ & $\begin{array}{l}19.4 \\
(4.7)\end{array}$ & $\begin{array}{l}4.20 \\
(0.98)\end{array}$ & $\begin{array}{l}295 \\
(24)\end{array}$ & $\begin{array}{c}3.35 \\
(0.29)\end{array}$ & $\begin{array}{c}0.436 \\
(0.006)\end{array}$ & $\begin{array}{l}113.1 \\
(1.9)\end{array}$ & & $\begin{array}{l}2.486 \\
(0.602)\end{array}$ & $\begin{array}{l}0.602 \\
(0.012)\end{array}$ & $\begin{array}{c}0.613 \\
(0.009)\end{array}$ & $\begin{array}{c}57.3 \\
()\end{array}$ & $\begin{array}{c}0.042 \\
(0.011)\end{array}$ \\
\hline $\begin{array}{c}\text { Dryobalanops } \\
\text { lanceolata }\end{array}$ & $\begin{array}{l}24.7 \\
(12.8)\end{array}$ & $\begin{array}{l}4.83 \\
(1.53)\end{array}$ & $\begin{array}{l}50.4 \\
(2.3)\end{array}$ & $\begin{array}{c}0.568 \\
(0.020)\end{array}$ & $\begin{array}{c}0.478 \\
(0.004)\end{array}$ & $\begin{array}{l}116.5 \\
(2.0)\end{array}$ & 244 & $\begin{array}{l}3.162 \\
(0.520)\end{array}$ & $\begin{array}{c}0.520 \\
(0.007)\end{array}$ & $\begin{array}{l}0.544 \\
(0.005)\end{array}$ & $\begin{array}{l}56.9 \\
(1.7)\end{array}$ & $\begin{array}{c}0.044 \\
(0.010)\end{array}$ \\
\hline $\begin{array}{l}\text { Duabanga } \\
\text { moluccana }\end{array}$ & $\begin{array}{l}47.1 \\
(1.0)\end{array}$ & 3.27 & $\begin{array}{l}209 \\
(18)\end{array}$ & $\begin{array}{l}2.17 \\
(0.18)\end{array}$ & $\begin{array}{c}0.410 \\
(0.004)\end{array}$ & $\begin{array}{l}104.7 \\
(1.9)\end{array}$ & & $\begin{array}{c}2.519 \\
(0.575)\end{array}$ & $\begin{array}{l}0.575 \\
(0.012)\end{array}$ & $\begin{array}{c}0.614 \\
(0.010)\end{array}$ & $\begin{array}{l}61.6 \\
(2.6)\end{array}$ & $\begin{array}{l}0.031 \\
(0.014)\end{array}$ \\
\hline Durio kutejensis & $\begin{array}{l}6.61 \\
(0.59)\end{array}$ & $\begin{array}{l}5.34 \\
(0.35)\end{array}$ & $\begin{array}{l}108 \\
(5)\end{array}$ & $\begin{array}{c}0.614 \\
(0.031)\end{array}$ & $\begin{array}{c}0.336 \\
(0.004)\end{array}$ & $\begin{array}{l}56.0 \\
(0.7)\end{array}$ & $\begin{array}{l}167 \\
(1)\end{array}$ & $\begin{array}{c}2.865 \\
(0.554)\end{array}$ & $\begin{array}{c}0.554 \\
(0.006)\end{array}$ & $\begin{array}{c}0.567 \\
(0.003)\end{array}$ & $\begin{array}{c}26.4 \\
()\end{array}$ & $\begin{array}{l}0.024 \\
(0.005)\end{array}$ \\
\hline $\begin{array}{c}\text { Etlingera } \\
\text { brevilabrum }\end{array}$ & $\begin{array}{l}11.8 \\
(3.9)\end{array}$ & $\begin{array}{l}7.23 \\
(2.33)\end{array}$ & $\begin{array}{l}978 \\
(40)\end{array}$ & $\begin{array}{l}10.2 \\
(0.7)\end{array}$ & $\begin{array}{c}0.334 \\
(0.007)\end{array}$ & $\begin{array}{l}102.1 \\
(3.3)\end{array}$ & $\begin{array}{c}303 \\
(3)\end{array}$ & $\begin{array}{l}4.071 \\
(0.453)\end{array}$ & $\begin{array}{l}0.453 \\
(0.009)\end{array}$ & $\begin{array}{l}0.499 \\
(0.006)\end{array}$ & $\begin{array}{l}58.1 \\
(1.4)\end{array}$ & $\begin{array}{l}0.007 \\
(0.003)\end{array}$ \\
\hline $\begin{array}{c}\text { Euphoria } \\
\text { malaiensis }= \\
\text { Dimocarpus longan }\end{array}$ & $\begin{array}{l}36.4 \\
(4.8)\end{array}$ & $\begin{array}{l}13.5 \\
(2.4)\end{array}$ & $\begin{array}{l}74.0 \\
(5.4)\end{array}$ & 0.672 & & $\begin{array}{l}105.1 \\
(2.1)\end{array}$ & $\begin{array}{l}194 \\
(2)\end{array}$ & $\begin{array}{c}3.042 \\
(0.499)\end{array}$ & $\begin{array}{c}0.499 \\
(0.010)\end{array}$ & $\begin{array}{c}0.546 \\
(0.006)\end{array}$ & $\begin{array}{l}16.3 \\
(0.6)\end{array}$ & $\begin{array}{c}0.047 \\
(0.013)\end{array}$ \\
\hline Eurycoma longifolia & $\begin{array}{l}4.0 \\
(2.0)\end{array}$ & $\begin{array}{c}2.07 \\
(1.72)\end{array}$ & $\begin{array}{l}18.2 \\
(0.5)\end{array}$ & & $\begin{array}{l}0.376 \\
(0.005)\end{array}$ & $\begin{array}{l}47.0 \\
(0.7)\end{array}$ & $\begin{array}{l}125 \\
(1)\end{array}$ & $\begin{array}{l}3.335 \\
(0.494)\end{array}$ & $\begin{array}{l}0.494 \\
(0.006)\end{array}$ & $\begin{array}{c}0.523 \\
(0.005)\end{array}$ & $\begin{array}{l}38.6 \\
(0.7)\end{array}$ & $\begin{array}{l}0.020 \\
(0.006)\end{array}$ \\
\hline $\begin{array}{c}\text { Eusideroxylon } \\
\text { zwageri }\end{array}$ & $\begin{array}{l}22.1 \\
(7.0)\end{array}$ & $\begin{array}{l}16.1 \\
(5.9)\end{array}$ & 263 & 3.35 & $\begin{array}{l}0.418 \\
(0.006)\end{array}$ & $\begin{array}{l}129.3 \\
(2.0)\end{array}$ & $\begin{array}{l}310 \\
(3)\end{array}$ & $\begin{array}{c}2.555 \\
(0.608)\end{array}$ & $\begin{array}{l}0.608 \\
(0.011)\end{array}$ & $\begin{array}{l}0.614 \\
(0.009)\end{array}$ & $\begin{array}{l}20.7 \\
(0.8)\end{array}$ & $\begin{array}{c}0.034 \\
(0.008)\end{array}$ \\
\hline Fagraea cuspidata & $\begin{array}{c}5.21 \\
(4.09)\end{array}$ & $\begin{array}{c}0.232 \\
(0.230)\end{array}$ & & & $\begin{array}{c}0.385 \\
(0.007)\end{array}$ & $\begin{array}{l}147.6 \\
(7.8)\end{array}$ & $\begin{array}{l}376 \\
(14)\end{array}$ & $\begin{array}{c}1.884 \\
(0.678)\end{array}$ & $\begin{array}{c}0.678 \\
(0.010)\end{array}$ & $\begin{array}{c}0.720 \\
(0.010)\end{array}$ & $\begin{array}{l}175 \\
(3.7)\end{array}$ & $\begin{array}{c}0.010 \\
(0.006)\end{array}$ \\
\hline $\begin{array}{c}\text { Fordia } \\
\text { splendidissima }\end{array}$ & $\begin{array}{l}23.3 \\
(5.8)\end{array}$ & & & $\begin{array}{l}0.342 \\
(0.018)\end{array}$ & $\begin{array}{c}0.379 \\
(0.006)\end{array}$ & $\begin{array}{l}46.9 \\
(1.2)\end{array}$ & $\begin{array}{l}124 \\
(2)\end{array}$ & $\begin{array}{c}2.542 \\
(0.578)\end{array}$ & $\begin{array}{c}0.578 \\
(0.011)\end{array}$ & $\begin{array}{l}0.592 \\
(0.008)\end{array}$ & $\begin{array}{l}15.8 \\
(1.0)\end{array}$ & $\begin{array}{l}0.065 \\
(0.013)\end{array}$ \\
\hline $\begin{array}{c}\text { Goniothalamus } \\
\text { uvarioides }\end{array}$ & $\begin{array}{l}22.8 \\
(5.0)\end{array}$ & $\begin{array}{l}7.75 \\
(1.32)\end{array}$ & $\begin{array}{l}470 \\
(23)\end{array}$ & $\begin{array}{c}2.99 \\
(1.70)\end{array}$ & $\begin{array}{c}0.338 \\
(0.006)\end{array}$ & $\begin{array}{l}62.7 \\
(1.5)\end{array}$ & $\begin{array}{l}185 \\
(2)\end{array}$ & $\begin{array}{c}2.764 \\
(0.579)\end{array}$ & $\begin{array}{l}0.579 \\
(0.009)\end{array}$ & $\begin{array}{l}0.586 \\
(0.007)\end{array}$ & $\begin{array}{l}23.4 \\
(0.7)\end{array}$ & $\begin{array}{c}0.029 \\
(0.007)\end{array}$ \\
\hline Helicia & 2.7 & 1.90 & 1386 & 16.6 & 0.402 & 123.0 & 306 & 1.388 & 0.039 & 0.597 & 104 & 0.120 \\
\hline
\end{tabular}




\begin{tabular}{|c|c|c|c|c|c|c|c|c|c|c|c|c|}
\hline artocarpoides & $(0.8)$ & $(0.55)$ & (143) & (1.7) & $(0.004)$ & (3.1) & (7) & $(0.039)$ & $(0.003)$ & $(0.011)$ & (8.2) & .018 \\
\hline Hopea nervosa & $\begin{array}{c}7.4 \\
(7.4)\end{array}$ & $\begin{array}{l}6.84 \\
(2.54)\end{array}$ & $\begin{array}{l}38.1 \\
(1.6)\end{array}$ & $\begin{array}{c}0.334 \\
(0.019)\end{array}$ & $\begin{array}{l}0.470 \\
(0.004)\end{array}$ & $\begin{array}{l}86.6 \\
(2.3)\end{array}$ & $\begin{array}{c}184 \\
(4)\end{array}$ & $\begin{array}{l}2.586 \\
(0.566)\end{array}$ & $\begin{array}{l}0.566 \\
(0.009)\end{array}$ & $\begin{array}{l}0.584 \\
(0.006)\end{array}$ & $\begin{array}{l}23.6 \\
(0.6)\end{array}$ & $\begin{array}{c}0.035 \\
(0.006)\end{array}$ \\
\hline Hopea nutans & $\begin{array}{c}83.1 \\
(30.4)\end{array}$ & $\begin{array}{l}13.0 \\
(5.2)\end{array}$ & $\begin{array}{l}50.2 \\
(1.5)\end{array}$ & $\begin{array}{c}0.537 \\
(0.017)\end{array}$ & $\begin{array}{c}0.493 \\
(0.004)\end{array}$ & 107.9 & $\begin{array}{l}218 \\
(4)\end{array}$ & $\begin{array}{l}2.033 \\
(0.631)\end{array}$ & $\begin{array}{l}0.631 \\
(0.007)\end{array}$ & $\begin{array}{c}0.643 \\
(0.007)\end{array}$ & $\begin{array}{l}12.3 \\
(0.5)\end{array}$ & $\begin{array}{l}0.036 \\
(0.010)\end{array}$ \\
\hline Hopea sangal & $\begin{array}{l}34.6 \\
(15.8)\end{array}$ & $\begin{array}{c}4.38 \\
(2.01)\end{array}$ & $\begin{array}{l}43.9 \\
(2.9)\end{array}$ & $\begin{array}{c}0.428 \\
(0.027)\end{array}$ & $\begin{array}{l}0.473 \\
(0.005)\end{array}$ & 100.3 & 212 & $\begin{array}{l}2.293 \\
(0.586)\end{array}$ & $\begin{array}{l}0.586 \\
(0.009)\end{array}$ & $\begin{array}{l}0.615 \\
0.006\end{array}$ & $(09)$ & $\begin{array}{c}0.028 \\
(0.007)\end{array}$ \\
\hline Ixora grandifolia & $\begin{array}{l}(15.8) \\
22.6 \\
(8.6)\end{array}$ & $\begin{array}{l}11.3 \\
(2.41)\end{array}$ & $\begin{array}{l}(2.9) \\
105 \\
(5)\end{array}$ & $\begin{array}{l}1.01 \\
(0.05)\end{array}$ & $\begin{array}{c}(.005) \\
0.336 \\
(0.003)\end{array}$ & $\begin{array}{l}(1.4) \\
96.0 \\
(1.2)\end{array}$ & $\begin{array}{c}(2) \\
286 \\
(2)\end{array}$ & $\begin{array}{l}(.080) \\
2.434 \\
(0.598)\end{array}$ & $\begin{array}{l}0.098) \\
0.598 \\
(0.007)\end{array}$ & $\begin{array}{c}(0.000) \\
0.605 \\
(0.005)\end{array}$ & $\begin{array}{l}\text { (0.9) } \\
\text { (1.2) }\end{array}$ & $\begin{array}{c}(0.0046 \\
0.046 \\
(0.006)\end{array}$ \\
\hline Knema latericia & $\begin{array}{c}4.5 \\
(2.0)\end{array}$ & $\begin{array}{l}1.06 \\
(0.49)\end{array}$ & $\begin{array}{l}47.3 \\
(2.6)\end{array}$ & $\begin{array}{c}0.256 \\
(0.014)\end{array}$ & $\begin{array}{l}0.339 \\
(0.008)\end{array}$ & $\begin{array}{l}55.8 \\
(1.4)\end{array}$ & $\begin{array}{l}165 \\
(2)\end{array}$ & $\begin{array}{l}4.242 \\
(0.425)\end{array}$ & $\begin{array}{c}0.425 \\
(0.011)\end{array}$ & $\begin{array}{l}0.483 \\
(0.008)\end{array}$ & $\begin{array}{l}21.7 \\
(0.6)\end{array}$ & $\begin{array}{c}0.055 \\
(0.009)\end{array}$ \\
\hline $\begin{array}{l}\text { Lansium } \\
\text { domesticum }\end{array}$ & $\begin{array}{c}5.0 \\
(1.6)\end{array}$ & $\begin{array}{l}1.23 \\
(0.41)\end{array}$ & $\begin{array}{l}96.5 \\
(4.7)\end{array}$ & $\begin{array}{c}0.692 \\
(0.038)\end{array}$ & $\begin{array}{l}0.369 \\
(0.005)\end{array}$ & $\begin{array}{l}71.1 \\
(1.9)\end{array}$ & $\begin{array}{l}191 \\
(3)\end{array}$ & $\begin{array}{l}2.305 \\
(0.646)\end{array}$ & $\left(\begin{array}{l}0.646 \\
(0.007)\end{array}\right.$ & $\begin{array}{l}0.634 \\
(0.007)\end{array}$ & $\begin{array}{l}67.8 \\
(2.2)\end{array}$ & $\begin{array}{c}0.090 \\
(0.014)\end{array}$ \\
\hline Leea indica & $\begin{array}{l}37.5 \\
(18.6)\end{array}$ & $\begin{array}{c}6.21 \\
(3.01)\end{array}$ & $\begin{array}{l}109 \\
(4)\end{array}$ & $\begin{array}{c}0.659 \\
(0.031)\end{array}$ & $\begin{array}{c}0.288 \\
(0.005)\end{array}$ & $\begin{array}{l}60.7 \\
(1.4)\end{array}$ & $\begin{array}{r}211 \\
(3)\end{array}$ & $\begin{array}{l}2.576 \\
(0.540)\end{array}$ & $\begin{array}{l}0.540 \\
(0.007)\end{array}$ & $\begin{array}{l}0.573 \\
(0.005)\end{array}$ & $\begin{array}{l}49.7 \\
(2.1)\end{array}$ & $\begin{array}{l}0.038 \\
(0.006)\end{array}$ \\
\hline $\begin{array}{l}\text { Lophoetalum } \\
\text { beccarianum }\end{array}$ & $\begin{array}{c}23.0 \\
(11.1)\end{array}$ & $\begin{array}{c}7.69 \\
(2.29)\end{array}$ & $\begin{array}{l}188 \\
(12)\end{array}$ & $\begin{array}{l}1.08 \\
(0.06)\end{array}$ & $\begin{array}{l}0.340 \\
(0.006)\end{array}$ & $\begin{array}{l}60.7 \\
(1.9)\end{array}$ & $\begin{array}{l}178 \\
(4)\end{array}$ & $\begin{array}{c}2.807 \\
(0.581)\end{array}$ & $\begin{array}{l}0.581 \\
(0.010)\end{array}$ & $\begin{array}{l}0.585 \\
(0.008)\end{array}$ & $\begin{array}{l}58.6 \\
(2.1)\end{array}$ & $\begin{array}{c}0.089 \\
(0.010)\end{array}$ \\
\hline Ludekia borneensis & $\begin{array}{l}4.86 \\
(3.52)\end{array}$ & $\begin{array}{c}4.67 \\
(3.08)\end{array}$ & $\begin{array}{l}49.3 \\
(1.7)\end{array}$ & $\begin{array}{c}0.567 \\
(0.020)\end{array}$ & $\begin{array}{c}0.428 \\
(0.006)\end{array}$ & $\begin{array}{c}115.8 \\
(2.1)\end{array}$ & & & $\begin{array}{l}0.709 \\
(0.007)\end{array}$ & $\begin{array}{c}0.692 \\
(0.005)\end{array}$ & $\begin{array}{l}29.8 \\
(0.8)\end{array}$ & $\begin{array}{l}0.047 \\
(0.008)\end{array}$ \\
\hline $\begin{array}{c}\text { Luvunga } \\
\text { heterophylla }\end{array}$ & $\begin{array}{l}17.1 \\
(8.3)\end{array}$ & $\begin{array}{l}15.0 \\
(9.2)\end{array}$ & $\begin{array}{l}63.7 \\
(4.3)\end{array}$ & $\begin{array}{c}0.369 \\
(0.025)\end{array}$ & $\begin{array}{l}0.304 \\
(0.003)\end{array}$ & $\begin{array}{l}57.8 \\
(0.5)\end{array}$ & & $\begin{array}{l}2.835 \\
(0.533)\end{array}$ & $\begin{array}{c}0.533 \\
(0.007)\end{array}$ & $\begin{array}{l}0.550 \\
(0.006)\end{array}$ & $\begin{array}{l}34.2 \\
(0.9)\end{array}$ & $\begin{array}{c}0.063 \\
(0.010)\end{array}$ \\
\hline $\begin{array}{c}\text { Macaranga } \\
\text { gigantea }\end{array}$ & $\begin{array}{l}30.7 \\
(5.3)\end{array}$ & $\begin{array}{c}11.5 \\
(2.02)\end{array}$ & $\begin{array}{l}2603 \\
(214)\end{array}$ & $\begin{array}{l}19.7 \\
(1.9)\end{array}$ & $\begin{array}{c}0.361 \\
(0.007)\end{array}$ & $\begin{array}{l}73.9 \\
(2.0)\end{array}$ & & $\begin{array}{l}1.114 \\
(0.448)\end{array}$ & $\begin{array}{l}0.448 \\
(0.011)\end{array}$ & $\begin{array}{l}0.846 \\
(0.004)\end{array}$ & $\begin{array}{l}14.6 \\
(1.7)\end{array}$ & $\begin{array}{c}0.096 \\
(0.022)\end{array}$ \\
\hline $\begin{array}{l}\text { Macaranga } \\
\text { hypoleuca }\end{array}$ & $\begin{array}{l}25.1 \\
(2.9)\end{array}$ & $\begin{array}{c}3.13 \\
(0.339)\end{array}$ & $\begin{array}{l}232 \\
(14)\end{array}$ & $\begin{array}{l}2.17 \\
(0.11)\end{array}$ & $\begin{array}{c}0.442 \\
(0.011)\end{array}$ & $\begin{array}{l}97.2 \\
(2.5)\end{array}$ & $\begin{array}{l}221 \\
(4)\end{array}$ & $\begin{array}{l}1.264 \\
(0.429)\end{array}$ & $\begin{array}{c}0.429 \\
(0.008)\end{array}$ & $\begin{array}{l}0.744 \\
(0.007)\end{array}$ & $\begin{array}{l}19.9 \\
(1.6)\end{array}$ & $\begin{array}{c}0.046 \\
(0.011)\end{array}$ \\
\hline Macaranga triloba & $\begin{array}{l}21.1 \\
(7.6)\end{array}$ & $\begin{array}{l}6.01 \\
(1.54)\end{array}$ & $\begin{array}{l}339 \\
(32)\end{array}$ & $\begin{array}{l}3.16 \\
(0.26)\end{array}$ & $\begin{array}{c}0.430 \\
(0.007)\end{array}$ & $\begin{array}{l}96.7 \\
(3.1)\end{array}$ & $\begin{array}{l}220 \\
(3)\end{array}$ & $\begin{array}{c}1.379 \\
(0.482)\end{array}$ & $\begin{array}{c}0.482 \\
(0.012)\end{array}$ & $\begin{array}{c}0.779 \\
(0.010)\end{array}$ & $\begin{array}{l}53.3 \\
(7.4)\end{array}$ & $\begin{array}{l}0.143 \\
(0.031)\end{array}$ \\
\hline $\begin{array}{c}\text { Macaranga } \\
\text { pearsonii }\end{array}$ & $\begin{array}{l}20.6 \\
(4.2)\end{array}$ & $\begin{array}{c}3.36 \\
(0.717)\end{array}$ & $\begin{array}{l}377 \\
(23)\end{array}$ & $\begin{array}{c}2.83 \\
(0.23)\end{array}$ & $\begin{array}{l}0.434 \\
(0.010)\end{array}$ & $\begin{array}{l}73.5 \\
(2.6)\end{array}$ & $\begin{array}{c}174 \\
(9)\end{array}$ & $\begin{array}{c}1.219 \\
(0.416)\end{array}$ & $\begin{array}{c}0.416 \\
(0.007)\end{array}$ & $\begin{array}{c}0.773 \\
(0.008)\end{array}$ & $\begin{array}{l}33.7 \\
(3.3)\end{array}$ & $\begin{array}{c}0.062 \\
(0.020)\end{array}$ \\
\hline Madhuca korthalsii & $\begin{array}{l}10.6 \\
(2.7)\end{array}$ & $\begin{array}{c}0.885 \\
(0.223)\end{array}$ & $\begin{array}{l}650 \\
(34)\end{array}$ & $\begin{array}{c}5.43 \\
(0.30)\end{array}$ & $\begin{array}{l}0.325 \\
(0.007)\end{array}$ & $\begin{array}{l}84.6 \\
(2.2)\end{array}$ & $\begin{array}{c}260 \\
(4)\end{array}$ & $\begin{array}{l}2.311 \\
(0.612)\end{array}$ & $\begin{array}{c}0.612 \\
(0.013)\end{array}$ & $\begin{array}{c}0.628 \\
(0.007)\end{array}$ & $\begin{array}{l}70.7 \\
(3.3)\end{array}$ & $\begin{array}{l}0.047 \\
(0.013)\end{array}$ \\
\hline $\begin{array}{c}\text { Mallotus } \\
\text { mollissimus }\end{array}$ & $\begin{array}{c}27.4 \\
(14.6)\end{array}$ & $\begin{array}{l}3.01 \\
(1.41)\end{array}$ & $\begin{array}{l}83.3 \\
(5.0)\end{array}$ & $\begin{array}{l}0.463 \\
(0.026)\end{array}$ & $\begin{array}{l}0.458 \\
(0.008)\end{array}$ & $\begin{array}{l}65.8 \\
(2.0)\end{array}$ & $\begin{array}{l}124 \\
(3)\end{array}$ & $\begin{array}{l}1.273 \\
(0.710)\end{array}$ & $\begin{array}{c}0.710 \\
(0.006)\end{array}$ & $\begin{array}{l}0.803 \\
(0.006)\end{array}$ & $\begin{array}{l}38.0 \\
(1.6)\end{array}$ & $\begin{array}{c}0.029 \\
(0.007)\end{array}$ \\
\hline Mallotus wrayi & $\begin{array}{l}46.2 \\
(5.1)\end{array}$ & $\begin{array}{c}1.23 \\
(0.32)\end{array}$ & $\begin{array}{l}122 \\
(7)\end{array}$ & $\begin{array}{l}0.730 \\
(0.043)\end{array}$ & $\begin{array}{l}0.494 \\
(0.006)\end{array}$ & $\begin{array}{l}59.2 \\
(0.8)\end{array}$ & $\begin{array}{l}120 \\
(1)\end{array}$ & $\begin{array}{l}2.839 \\
(0.545)\end{array}$ & $\begin{array}{c}0.545 \\
(0.013)\end{array}$ & $\begin{array}{c}0.562 \\
(0.009)\end{array}$ & $\begin{array}{l}49.0 \\
(1.9)\end{array}$ & $\begin{array}{c}0.044 \\
(0.008)\end{array}$ \\
\hline $\begin{array}{c}\text { Melastoma } \\
\text { malabathricum }\end{array}$ & $\begin{array}{l}20.0 \\
(5.1)\end{array}$ & $\begin{array}{l}5.05 \\
(1.31)\end{array}$ & $\begin{array}{l}17.8 \\
(0.7)\end{array}$ & $\begin{array}{l}0.149 \\
(0.006)\end{array}$ & $\begin{array}{c}0.351 \\
(0.006)\end{array}$ & $\begin{array}{l}86.2 \\
(2.1)\end{array}$ & $\begin{array}{c}247 \\
(5)\end{array}$ & $\begin{array}{l}2.779 \\
(0.552)\end{array}$ & $\begin{array}{c}0.552 \\
(0.008)\end{array}$ & $\begin{array}{l}0.573 \\
(0.004)\end{array}$ & $\begin{array}{l}37.0 \\
(0.7)\end{array}$ & $\begin{array}{c}0.023 \\
(0.003)\end{array}$ \\
\hline $\begin{array}{l}\text { Memecylon } \\
\text { laevigatum }\end{array}$ & $\begin{array}{l}11.9 \\
(1.8)\end{array}$ & $\begin{array}{c}9.23 \\
(1.52)\end{array}$ & $\begin{array}{l}98.7 \\
(4.9)\end{array}$ & $\begin{array}{l}0.821 \\
(0.043)\end{array}$ & $\begin{array}{l}0.427 \\
(0.004)\end{array}$ & $\begin{array}{l}84.1 \\
(1.8)\end{array}$ & $\begin{array}{l}196 \\
(3)\end{array}$ & $\begin{array}{l}2.935 \\
(0.545)\end{array}$ & $\begin{array}{l}0.545 \\
(0.008)\end{array}$ & $\begin{array}{l}0.562 \\
(0.006)\end{array}$ & $\begin{array}{l}35.6 \\
(0.6)\end{array}$ & $\begin{array}{c}0.048 \\
(0.014)\end{array}$ \\
\hline $\begin{array}{l}\text { Neonauclea } \\
\text { artocarpioides }\end{array}$ & $\begin{array}{c}40.4 \\
(12.4)\end{array}$ & & $\begin{array}{l}580 \\
(44)\end{array}$ & $\begin{array}{l}6.56 \\
(0.75)\end{array}$ & $\begin{array}{l}0.350 \\
(0.014)\end{array}$ & $\begin{array}{l}108.6 \\
(5.5)\end{array}$ & $\begin{array}{c}307 \\
(6)\end{array}$ & $\begin{array}{c}1.453 \\
(0.783)\end{array}$ & $\begin{array}{c}0.783 \\
(0.005)\end{array}$ & $\begin{array}{l}0.808 \\
(0.009)\end{array}$ & $\begin{array}{l}33.2 \\
(1.9)\end{array}$ & $\begin{array}{c}0.111 \\
(0.017)\end{array}$ \\
\hline $\begin{array}{l}\text { Nephelium } \\
\text { ramboutan-ake }\end{array}$ & $\begin{array}{c}48.4 \\
(16.1)\end{array}$ & & $\begin{array}{l}33.5 \\
(1.6)\end{array}$ & $\begin{array}{c}0.180 \\
(0.010)\end{array}$ & $\begin{array}{c}0.414 \\
(0.006)\end{array}$ & $\begin{array}{l}52.7 \\
(0.9)\end{array}$ & $\begin{array}{c}127 \\
(2)\end{array}$ & $\begin{array}{l}2.670 \\
(0.575)\end{array}$ & $\begin{array}{c}0.575 \\
(0.009)\end{array}$ & $\begin{array}{l}0.585 \\
(0.007)\end{array}$ & $\begin{array}{l}4.27 \\
(2.1)\end{array}$ & $\begin{array}{c}0.072 \\
(0.009)\end{array}$ \\
\hline
\end{tabular}




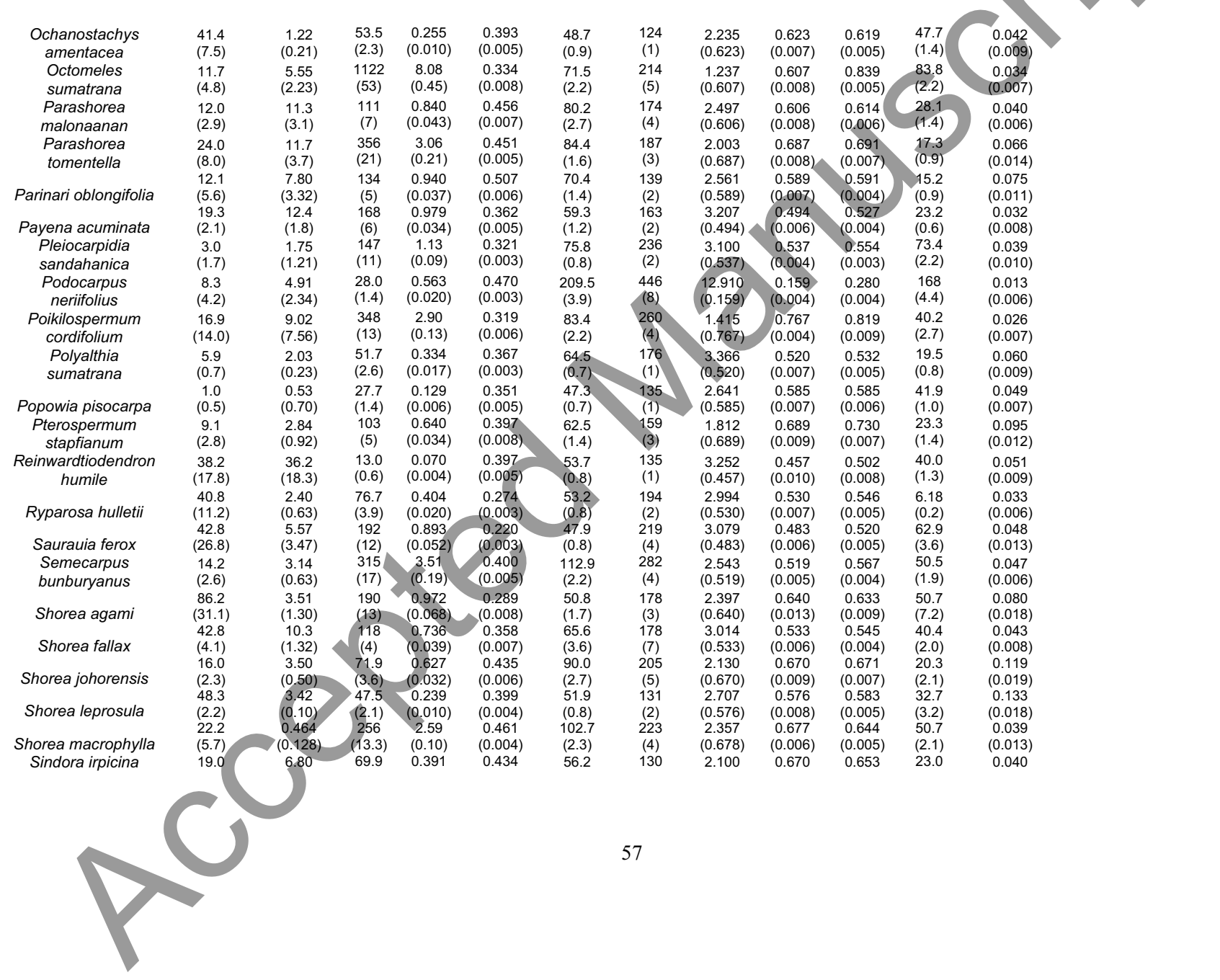




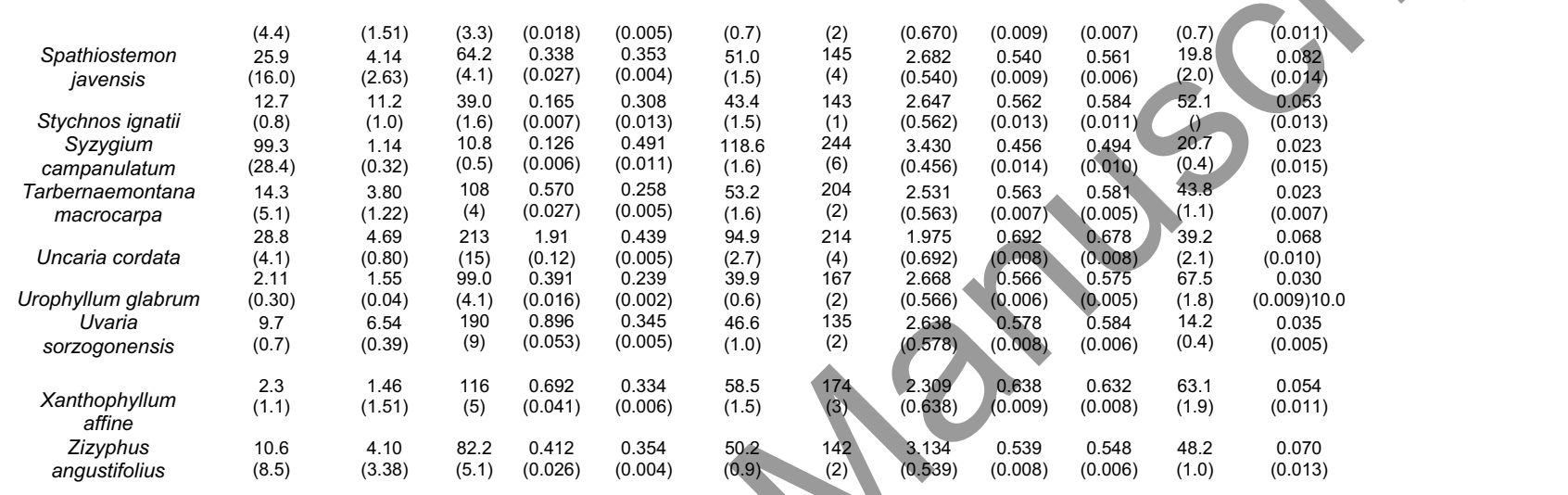


Table S5. Pearson's coefficients and levels of significance (p) of the correlations between element contents and ratios with leaf phenolics and tannin contents, $A_{\text {mass }}$ (leaf photosynthetic rate per unit of leaf mass), morphological traits and accumulated folivory (F), maximum accumulated folivory (MaxF) and the accumulated folivory coefficient of variation (CVF) in 88 rainforest plants of Borneo. Significant correlations at $p<0.05$ $(\mathrm{p}<0.001$ after Bonferroni correction) are in bold.

\begin{tabular}{|c|c|c|c|c|c|c|c|c|c|c|c|c|c|c|}
\hline & TP & $T$ & ea & MA & $\mathrm{AF}$ & $F$ & L & $\mathbf{R}$ & com & & & $F$ & MaxF & CVF \\
\hline C & .264 & 0.230 & 6 & $\begin{array}{l}R=-0 . \\
p=0.3\end{array}$ & $\begin{array}{l}R=-0 . \\
p=0.1\end{array}$ & $\begin{array}{l}R=0.0 \\
p=0.6\end{array}$ & $\begin{array}{l}=0.084 \\
=0.435\end{array}$ & & 6 & $\begin{array}{l}163 \\
30\end{array}$ & $\begin{array}{l}129 \\
159\end{array}$ & $\begin{array}{l}39 \\
9\end{array}$ & & \\
\hline $\mathbf{N}$ & $\begin{array}{l}=-0.235 \\
0.027\end{array}$ & $\begin{array}{l}R=-0.344 \\
p=0.001\end{array}$ & $\begin{array}{l}R=-0.038 \\
p=0.726\end{array}$ & $\begin{array}{l}R=-0.334 \\
p=0.001\end{array}$ & $\begin{array}{l}R=-0.291 \\
p=0.006\end{array}$ & $\begin{array}{l}R=-0.168 \\
p=0.117\end{array}$ & $\begin{array}{l}R=-0.023 \\
p=0.832\end{array}$ & & & $\begin{array}{l}R=0.001 \\
p=0.998\end{array}$ & $\begin{array}{l}R=0.413 \\
p=0.001\end{array}$ & $\begin{array}{l}57 \\
7\end{array}$ & & \\
\hline $\mathrm{Ca}$ & $\begin{array}{l}R=0.164 \\
p=0.128\end{array}$ & $R=0.153$ & $\begin{array}{l}R=0.1393 \\
p=0.195\end{array}$ & $\begin{array}{l}R=0.355 \\
p<0.001\end{array}$ & $\begin{array}{l}R=0.389 \\
p<0.001\end{array}$ & $\begin{array}{l}R=0.044 \\
p=0.686\end{array}$ & $\begin{array}{l}R=0.020 \\
p=0.857\end{array}$ & 2 & $\begin{array}{l}R=0 \\
p=0 .\end{array}$ & $\begin{array}{l}R=-0.014 \\
p=0.898\end{array}$ & $\begin{array}{l}R=0.003 \\
p=0.986\end{array}$ & $\begin{array}{l}R=-0.001 \\
p=0.993\end{array}$ & & \\
\hline $\mathrm{K}$ & $\begin{array}{l}R=-0.283 \\
p=0.007\end{array}$ & $\begin{array}{l}R=-0.111 \\
p=0.302\end{array}$ & $\begin{array}{l}R=-0.003 \\
p=0.979\end{array}$ & $\begin{array}{l}R=-0.066 \\
p=0.544\end{array}$ & $\begin{array}{l}R=0.103 \\
p=0.339\end{array}$ & $\begin{array}{l}R=-0.355 \\
p=0.001\end{array}$ & $\begin{array}{l}R=0.068 \\
p=0.528\end{array}$ & & & $\begin{array}{l}R=-0.101 \\
p=0.352\end{array}$ & $\begin{array}{l}R=0.086 \\
p=0.623\end{array}$ & $\begin{array}{l}R=-0.273 \\
P<0.001\end{array}$ & & $\begin{array}{l}R=-0 \\
p=0 .\end{array}$ \\
\hline M & $\begin{array}{l}=-0.188 \\
=0.080\end{array}$ & $\begin{array}{l}R=-0.073 \\
p=0.497\end{array}$ & $\begin{array}{l}R=0.027 \\
p=0.802\end{array}$ & $\begin{array}{l}R=0.1 \\
p=0.1\end{array}$ & $\begin{array}{l}R=0.264 \\
p=0.013\end{array}$ & $\begin{array}{l}R=-0.170 \\
p=0.114\end{array}$ & $\begin{array}{l}R=0.098 \\
p=0.362\end{array}$ & & $\begin{array}{l}R=-0 \\
p=0 .\end{array}$ & $\begin{array}{l}R=-0.034 \\
p=0.754\end{array}$ & $\begin{array}{l}R=-0.040 \\
p=0.820\end{array}$ & $\begin{array}{l}R=-0 . \\
p=0.5\end{array}$ & & $\begin{array}{l}R=0 \\
p=0\end{array}$ \\
\hline S & $\begin{array}{l}=-0.160 \\
=0.136\end{array}$ & $\begin{array}{l}R=-0.290 \\
p=0.006\end{array}$ & $\begin{array}{l}R=0.065 \\
p=0.548\end{array}$ & $\begin{array}{l}R=-0.065 \\
p=0.546\end{array}$ & $\begin{array}{l}R=-0 \\
p=0.9\end{array}$ & $\begin{array}{l}R=-0.117 \\
p=0.278\end{array}$ & $\begin{array}{l}R=0.030 \\
p=0.783\end{array}$ & $\begin{array}{l}R=-0.002 \\
p=0.983\end{array}$ & $\begin{array}{l}R=0 \\
p=0\end{array}$ & $\begin{array}{l}R=-0.095 \\
p=0.379\end{array}$ & $\begin{array}{l}R=0.117 \\
p=0.502\end{array}$ & $\begin{array}{l}R=-0 \\
p=0 .\end{array}$ & & $\begin{array}{l}R=- \\
p=0\end{array}$ \\
\hline $\mathbf{P}$ & $\begin{array}{l}=.0230 \\
=0.832\end{array}$ & $\begin{array}{l}R=-0.104 \\
p=0.337\end{array}$ & $\begin{array}{l}R=-0.043 \\
p=0.690\end{array}$ & $\begin{array}{l}R=-0.053 \\
p=0.623\end{array}$ & $\begin{array}{l}R=-0.106 \\
p=0.326\end{array}$ & $\begin{array}{l}R=0.084 \\
p=0.438\end{array}$ & $\begin{array}{l}R=-0.056 \\
p=0.607\end{array}$ & $\begin{array}{l}R=-0.033 \\
p=0.765\end{array}$ & $\begin{array}{l}R=0 . \\
p=0 .\end{array}$ & $\begin{array}{l}R=-0.106 \\
p=0.324\end{array}$ & $\begin{array}{l}R=0.184 \\
p=0.289\end{array}$ & $\begin{array}{l}R=-0.144 \\
p=0.182\end{array}$ & & $\begin{array}{l}R=-( \\
p=0 .\end{array}$ \\
\hline $\mathrm{Na}$ & $\begin{array}{l}R=0.200 \\
p=0.031\end{array}$ & $\begin{array}{l}R=0.209 \\
p=0.050\end{array}$ & $\begin{array}{l}R=-0.172 \\
p=0.110\end{array}$ & $\begin{array}{l}R=0.095 \\
p=0.380\end{array}$ & $\begin{array}{l}R=0.044 \\
p=0.683\end{array}$ & $\begin{array}{l}R=0.102 \\
p=0.329\end{array}$ & $\begin{array}{l}R=0.067 \\
p=0.535\end{array}$ & $\begin{array}{l}=-0.120 \\
=0.274\end{array}$ & $\begin{array}{l}R=-0 \\
p=0 .\end{array}$ & $\begin{array}{l}R=-0.053 \\
p=0.0623\end{array}$ & $\begin{array}{l}R=0.238 \\
p=0.168\end{array}$ & $\begin{array}{l}R=-0.131 \\
p=0.225\end{array}$ & & $\begin{array}{l}R=-0.037 \\
p=0.729\end{array}$ \\
\hline $\mathrm{Fe}$ & $\begin{array}{l}R=0.215 \\
p=0.044\end{array}$ & $\begin{array}{l}R=-0.026 \\
p=0.809\end{array}$ & $\begin{array}{l}R=0.083 \\
p=0.443\end{array}$ & $\begin{array}{l}R=-0.142 \\
p=0.186\end{array}$ & & $\begin{array}{l}R=0.038 \\
p=0.726\end{array}$ & $\begin{array}{l}R=-0 . \\
p=0.0\end{array}$ & $\begin{array}{l}R=0.198 \\
p=0.070\end{array}$ & $p=0$ & $\begin{array}{l}240 \\
25\end{array}$ & $\begin{array}{l}R=0.369 \\
p=0.029\end{array}$ & $\begin{array}{l}R=0 . \\
p=0 .\end{array}$ & $\begin{array}{l}75 \\
04\end{array}$ & $\begin{array}{l}R=0.0 \\
p=0.90\end{array}$ \\
\hline $\mathrm{Mn}$ & $\begin{array}{l}R=-0.020 \\
p=0.857\end{array}$ & $\begin{array}{l}R=-0.200 \\
p=0.061\end{array}$ & $\begin{array}{l}R=0.055 \\
p=0.614\end{array}$ & $\begin{array}{l}R=-0.087 \\
p=0.421\end{array}$ & $\begin{array}{l}R=-0.054 \\
p=0.616\end{array}$ & $\begin{array}{l}R=-0.058 \\
p=0.595\end{array}$ & $\begin{array}{l}R=-0.095 \\
p=0.380\end{array}$ & $\begin{array}{l}R=-0.102 \\
p=0.353\end{array}$ & $\begin{array}{l}R=0.046 \\
p=0.669\end{array}$ & $\begin{array}{l}R=-0.043 \\
p=0.692\end{array}$ & $\begin{array}{l}R=0.111 \\
p=0.526\end{array}$ & $\begin{array}{l}R=0.127 \\
p=0.240\end{array}$ & & $\begin{array}{l}R=-0.075 \\
p=0.485\end{array}$ \\
\hline v & $\begin{array}{l}R=0.174 \\
p=0.105\end{array}$ & $\begin{array}{l}R=-0.013 \\
p=0.904\end{array}$ & $\begin{array}{l}R=-0.079 \\
p=0.464\end{array}$ & $\begin{array}{l}R=-0.154 \\
p=0.153\end{array}$ & $\begin{array}{l}R=-0.192 \\
p=0.073\end{array}$ & $\begin{array}{l}R=0 \\
p=0 .\end{array}$ & 56 & $\begin{array}{l}37 \\
0\end{array}$ & $\begin{array}{l}7 \\
8\end{array}$ & $\begin{array}{l}65 \\
47\end{array}$ & $\begin{array}{l}R=0.274 \\
p=0.111\end{array}$ & $\begin{array}{l}R=0 \\
p=0\end{array}$ & & $p=0.8$ \\
\hline $\mathrm{Cr}$ & $\begin{array}{l}R=0.061 \\
p=0.575\end{array}$ & $\begin{array}{l}R=0.056 \\
p=0.606\end{array}$ & $\begin{array}{l}R=0.2033 \\
p=0.057\end{array}$ & $\begin{array}{l}R=-0.122 \\
p=0.258\end{array}$ & $\begin{array}{l}R=-0.072 \\
p=0.506\end{array}$ & $\begin{array}{l}R=-0.117 \\
p=0.279\end{array}$ & $\begin{array}{l}R=-0.201 \\
p=0.061\end{array}$ & $\begin{array}{l}R=0.142 \\
p=0.195\end{array}$ & $\begin{array}{l}R=0.174 \\
p=0.105\end{array}$ & $\begin{array}{l}R=0.044 \\
p=0.688\end{array}$ & $\begin{array}{l}R=0.050 \\
p=0.776\end{array}$ & $\begin{array}{l}R=0.169 \\
p=0.116\end{array}$ & $\begin{array}{l}R=0.158 \\
p=0.143\end{array}$ & $\begin{array}{l}R=0.116 \\
p=0.281\end{array}$ \\
\hline
\end{tabular}




\begin{tabular}{|c|c|c|c|c|c|c|c|c|c|c|c|c|c|c|}
\hline $\mathrm{Ni}$ & & $\begin{array}{l}R=-0.131 \\
p=0.223\end{array}$ & $\begin{array}{l}R=-0.053 \\
p=0.624\end{array}$ & $\begin{array}{l}R=-0.159 \\
p=0.138\end{array}$ & $\begin{array}{l}R=-0.157 \\
p=0.144\end{array}$ & $\begin{array}{l}R=-0.052 \\
p=0.632\end{array}$ & $\begin{array}{l}R=-0.040 \\
p=0.709\end{array}$ & $\begin{array}{l}R=0 \\
p=0 .\end{array}$ & $\begin{array}{l}R=-0.067 \\
p=0.537\end{array}$ & $\begin{array}{l}R=0.028 \\
p=0.796\end{array}$ & $p=0$ & $\begin{array}{l}R=0.127 \\
p=0.238\end{array}$ & $\begin{array}{l}R=0.227 \\
p=0.034\end{array}$ & $\begin{array}{l}85 \\
29\end{array}$ \\
\hline $\mathrm{Cu}$ & & $\begin{array}{l}94 \\
1 \\
\end{array}$ & $\begin{array}{l}R \\
p\end{array}$ & 97 & $\begin{array}{l}24 \\
2\end{array}$ & 8 & $\begin{array}{l}67 \\
9 \\
9\end{array}$ & $\begin{array}{l}R=-0.065 \\
p=0.557\end{array}$ & $\begin{array}{l}16 \\
83 \\
\end{array}$ & $\begin{array}{l}35 \\
49 \\
\end{array}$ & $\begin{array}{l}351 \\
039 \\
\end{array}$ & $\begin{array}{l}R=-0.013 \\
p=0.902\end{array}$ & $\begin{array}{l}l=0.063 \\
=0.559\end{array}$ & \\
\hline $\mathbf{Z n}$ & & & & & & & & $\begin{array}{l}R=-0.022 \\
p=0.840\end{array}$ & & & & $\begin{array}{l}R=-0.043 \\
p=0.694\end{array}$ & $\begin{array}{l}R=0.084 \\
p=0.434\end{array}$ & \\
\hline As & & & & & & & $\begin{array}{l}R=-0.056 \\
p=0.999\end{array}$ & $\begin{array}{l}R=0 \\
p=0\end{array}$ & & $\begin{array}{l}65 \\
45\end{array}$ & & $\begin{array}{l}R=0.074 \\
p=0.491\end{array}$ & $\begin{array}{l}=0.263 \\
=0.013\end{array}$ & \\
\hline $\mathrm{Sr}$ & & & & & $\begin{array}{l}R=0 . \\
p=0 .\end{array}$ & & & $\begin{array}{l}R=0-014 \\
p=0.900\end{array}$ & & & & $\begin{array}{l}R=-0.137 \\
p=0.202\end{array}$ & $\begin{array}{l}R=-0.083 \\
p=0.444\end{array}$ & \\
\hline Mo & & & & & & & & & $\begin{array}{l}R=0.090 \\
p=0.404\end{array}$ & & $\begin{array}{l}R=0.016 \\
p=0.927\end{array}$ & $\begin{aligned} R & =-0.108 \\
& =0.315\end{aligned}$ & $\begin{array}{l}R=0.014 \\
p=0.900\end{array}$ & \\
\hline Cd & & & & & $\begin{array}{l}R=0 . \\
p=0 .\end{array}$ & $\begin{array}{l}R=-0 . \\
p=0.8\end{array}$ & $\begin{array}{l}R=-0.053 \\
p=0.624\end{array}$ & & $\begin{array}{l}R=0.065 \\
p=0.547\end{array}$ & \begin{tabular}{|l|}
086 \\
24
\end{tabular} & $\begin{array}{l}.297 \\
.083\end{array}$ & $\begin{array}{l}R=-0.155 \\
p=0.149\end{array}$ & $\begin{array}{l}R=0.111 \\
p=0.303\end{array}$ & \\
\hline $\mathrm{Pb}$ & & $\begin{array}{l}-0.134 \\
0.212\end{array}$ & $\begin{array}{l}=-0.113 \\
0.296\end{array}$ & $\begin{array}{l}-0.206 \\
0.055\end{array}$ & $\begin{array}{l}R=-0.159 \\
p=0.138\end{array}$ & $\begin{array}{l}R=-0.153 \\
p=0.155\end{array}$ & $\begin{array}{l}R=0.029 \\
p=0.790\end{array}$ & & & $\begin{array}{l}R=-0.009 \\
p=0.934\end{array}$ & 303 & $\begin{array}{l}R=0.009 \\
p=0.932\end{array}$ & $\begin{array}{l}\mathrm{R}=0.170 \\
=0.114\end{array}$ & \\
\hline C:N & & $R=0.346$ & $\begin{array}{l}=-0.025 \\
=0.818\end{array}$ & $=0.350$ & $R=0.304$ & $\begin{array}{l}R=0.172 \\
p=0.110\end{array}$ & $\begin{array}{l}R=0 \\
p=0 .\end{array}$ & & $\begin{array}{l}R=-0.059 \\
p=0.586\end{array}$ & $\begin{array}{l}R=-0.034 \\
p=0.753\end{array}$ & $\begin{array}{l}R=-0.420 \\
p=0.0012\end{array}$ & $\begin{array}{l}R=-0.069 \\
p=0.525\end{array}$ & $\begin{array}{l}R=-0.140 \\
p=0.194\end{array}$ & \\
\hline$C: P$ & & $\begin{array}{l}R=0.116 \\
p=0.282\end{array}$ & & & & $\begin{array}{l}R=-0.059 \\
p=0.588\end{array}$ & $\begin{array}{l}R=0.037 \\
p=0.729\end{array}$ & $\begin{array}{l}R=0.051 \\
p=0.645\end{array}$ & $\begin{array}{l}R=-0.176 \\
p=0.100\end{array}$ & $\begin{array}{l}R=0.123 \\
p=0.254\end{array}$ & $\begin{array}{l}R=-0.217 \\
p=0.210\end{array}$ & $\begin{array}{l}R=0.148 \\
p=0.170\end{array}$ & $\begin{array}{l}R=0.008 \\
p=0.941\end{array}$ & \\
\hline$N: P$ & & $\begin{array}{l}R=-0.167 \\
p=0.119\end{array}$ & & & $\begin{array}{l}R=-0.108 \\
p=0.318\end{array}$ & $\begin{array}{l}R=-0.193 \\
p=0.071\end{array}$ & $\begin{array}{l}R=0.001 \\
p=0.972\end{array}$ & $\begin{array}{l}R=0.010 \\
p=0.930\end{array}$ & $\begin{array}{l}R=-0.123 \\
p=0.255\end{array}$ & $\begin{array}{l}R=0.167 \\
p=0.119\end{array}$ & $\begin{array}{l}=0.203 \\
=0.242\end{array}$ & $\begin{array}{l}R=0.152 \\
p=0.156\end{array}$ & $\begin{array}{l}R=0.077 \\
p=0.477\end{array}$ & \\
\hline C:K & $\begin{array}{l}91 \\
06 \\
\end{array}$ & $\begin{array}{l}R=0.122 \\
p=0.258\end{array}$ & & & $\begin{array}{l}R=-0.100 \\
p=0.355\end{array}$ & & $\begin{array}{l}R=-0.082 \\
p=0.449\end{array}$ & $\begin{array}{l}R=0.169 \\
p=0.123\end{array}$ & $\begin{array}{l}R=0 \\
p=0\end{array}$ & $\begin{array}{l}R=0 \\
p=0\end{array}$ & $\begin{array}{l}=-0.107 \\
=0.540\end{array}$ & $\begin{array}{l}R=0.284 \\
p=0.007\end{array}$ & $\begin{array}{l}R=0.248 \\
p=0.020\end{array}$ & \\
\hline $\mathrm{N}: \mathrm{K}$ & & $\begin{array}{l}R=-0.073 \\
p=0.502\end{array}$ & $\begin{array}{l}R=-0.008 \\
p=0.944\end{array}$ & $\begin{array}{l}R=-0.124 \\
p=0.250\end{array}$ & $\begin{array}{l}R=-0.234 \\
p=0.029\end{array}$ & $\begin{array}{l}R=0.1947 \\
p=0.069\end{array}$ & $\begin{array}{l}R=-0.103 \\
p=0.340\end{array}$ & $\begin{array}{l}R=0.145 \\
p=0.185\end{array}$ & & & $\begin{array}{l}=0.157 \\
=0.368\end{array}$ & $\begin{array}{l}R=0.292 \\
p=0.006\end{array}$ & $\begin{array}{l}R=0.302 \\
p=0.004\end{array}$ & \\
\hline P:K & $\begin{array}{l}0.301 \\
.004\end{array}$ & $\begin{array}{l}.038 \\
.728\end{array}$ & $\begin{array}{l}0.026 \\
.812\end{array}$ & & & & & $\begin{array}{l}R=0.131 \\
p=0.233\end{array}$ & & & $\begin{array}{l}039 \\
825\end{array}$ & $\begin{array}{l}74 \\
75\end{array}$ & 239 & \\
\hline
\end{tabular}

TP $=$ Total leaf phenolics

$\mathrm{TT}=$ Total leaf tannins

Area $=$ Leaf area

LMA = Leaf mass area (dry weight)

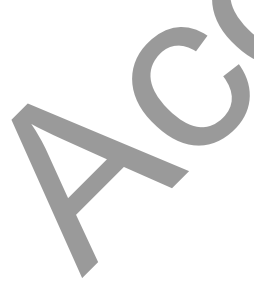


LMAF = Leaf mass area (fresh weight)

DF = Leaf (dry/fresh) weight

$\mathrm{L}=$ Leaf Length

$\mathrm{R}=$ Leaf Roundness

$\mathrm{COM}=$ Leaf Compactness

Per/Area $=$ Leaf $($ Perimeter/Area $)$

$A_{\text {mass }}=$ Photosynthetic rate per unity of leaf mass

MaxF = Maximum accumulated folivory

$\mathrm{CvF}=$ Coefficient of variation of accumulated folivory

$\mathrm{F}=$ Accumulated folivory 
Table S6. Pearson's coefficients and levels of significance (p) of the correlations between leaf phenolics and tannin contents, $A_{\text {mass }}($ leaf photosynthetic rate per unit of leaf mass), morphological traits with the accumulated folivory (F), maximum accumulated folivory (MaxF) and coefficient of variation of accumulated folivory (CVF) in 88 plants in a Bornean rainforest. Significant correlations at $p<0.05$ ( $p<0.0025$ after Bonferroni correction) are in bold.

\begin{tabular}{|c|c|c|c|c|c|c|c|c|c|c|c|}
\hline & TP & TT & Area & LMA & LMAF & DF & $\mathbf{L}$ & $\mathbf{R}$ & COM & Per/area & $A_{\text {mass }}$ \\
\hline MaxF & $\begin{array}{l}R=-0.094 \\
p=0.384\end{array}$ & $\begin{array}{l}R=-0.163 \\
p=0.129\end{array}$ & $\begin{array}{l}R=-0.089 \\
p=0.410\end{array}$ & $\begin{array}{l}R=-0.096 \\
p=0.372\end{array}$ & $\begin{array}{l}R=-0.129 \\
p=0.230\end{array}$ & $\begin{array}{l}R=0.044 \\
p=0.686\end{array}$ & $\begin{array}{l}R=-0.086 \\
p=0.424\end{array}$ & $\begin{array}{l}R=0.105 \\
p=0.338\end{array}$ & $\begin{array}{l}R=0.069 \\
p=0.520\end{array}$ & $\begin{array}{l}R=0.020 \\
p=0.851\end{array}$ & $\begin{array}{l}R=-0.044 \\
p=0.803\end{array}$ \\
\hline CVF & $\begin{array}{l}R=0.053 \\
p=0.627\end{array}$ & $\begin{array}{l}R=0.119 \\
p=0.270\end{array}$ & $\begin{array}{l}R=0.218 \\
p=0.042\end{array}$ & $\begin{array}{l}R=-0.086 \\
p=0.427\end{array}$ & $\begin{array}{l}R=-0.053 \\
p=0.623\end{array}$ & $\begin{array}{l}R=-0.074 \\
p=0.491\end{array}$ & $\begin{array}{l}R=-0.318 \\
p=0.003\end{array}$ & $\begin{array}{l}R=0.240 \\
p=0.027\end{array}$ & $\begin{array}{l}R=0.263 \\
p=0.013\end{array}$ & $\begin{array}{l}R=0.234 \\
p=0.028\end{array}$ & $\begin{array}{l}R=0.147 \\
p=0.399\end{array}$ \\
\hline$F$ & $\begin{array}{l}R=0.135 \\
p=0.212\end{array}$ & $\begin{array}{l}R=0.092 \\
p=0.396\end{array}$ & $\begin{array}{l}R=0.151 \\
p=0.162\end{array}$ & $\begin{array}{l}R=-0.135 \\
p=0.210\end{array}$ & $\begin{array}{l}R=-0.104 \\
p=0.333\end{array}$ & $\begin{array}{l}R=-0.065 \\
p=0.549\end{array}$ & $\begin{array}{l}R=-0.18 \\
p=0.090\end{array}$ & $\begin{array}{l}R=0.126 \\
p=0.250\end{array}$ & $\begin{array}{l}R=0.201 \\
p=0.060\end{array}$ & $\begin{array}{l}R=0.146 \\
p=0.175\end{array}$ & $\begin{array}{l}R=0.044 \\
p=0.800\end{array}$ \\
\hline
\end{tabular}

TP = Total leaf phenolics

$\mathrm{TT}=$ Total leaf tannins

Area $=$ Leaf area

LMA = Leaf mass area (dry weight)

LMAF $=$ Leaf mass area (fresh weight)

DF $=$ Leaf (dry/fresh) weight

$L=$ Leaf Length

$\mathrm{R}=$ Leaf Roundness

$\mathrm{COM}=$ Leaf Compactness

Per/Area $=$ Leaf $($ Perimeter/Area $)$

$A_{\text {mass }}=$ Photosynthetic rate per unity of leaf mass

MaxF = Maximum accumulated folivory

$\mathrm{CvF}=$ Coefficient of variation of accumulated folivory

$\mathrm{F}=$ Accumulated folivory 
Table S7. Pearson's coefficients and significant levels (p) of the correlations among total leaf phenolics and tannin contents, $A_{\text {mass }}($ leaf photosynthesis rate per unit of leaf mass), morphological traits and accumulated standing folivory in the 88 rainforest plants of the Borneo studied forest. Significant regressions at $\mathrm{p}<0.05$ ( $\mathrm{p}<0.001$ after Bonferroni correction) are in bold.

\begin{tabular}{|c|c|c|c|c|c|c|c|c|c|c|c|}
\hline & TT & Area & $\begin{array}{c}\text { Dry } \\
\text { weight }\end{array}$ & LMA & LMAF & DF & L & $\mathbf{R}$ & COM & Per./ar & $A_{\text {mass }}$ \\
\hline TP & $\begin{array}{l}R=0.401 \\
p<0.001\end{array}$ & $\begin{array}{l}R=0.081 \\
p=0.456\end{array}$ & $\begin{array}{l}R=0.132 \\
p=0.222\end{array}$ & $\begin{array}{l}R=0.220 \\
p=0.039\end{array}$ & $\begin{array}{l}R=0.105 \\
p=0.329\end{array}$ & $\begin{array}{l}R=0.299 \\
p=0.005\end{array}$ & $\begin{array}{l}R=-0.068 \\
p=0.532\end{array}$ & $\begin{array}{l}R=-0.035 \\
p=0.751\end{array}$ & $\begin{array}{l}R=0.077 \\
p=0.478\end{array}$ & $\begin{array}{l}R=-0.038 \\
p=0.724\end{array}$ & $\begin{array}{l}R=0.079 \\
P=0.652\end{array}$ \\
\hline TT & & $\begin{array}{l}R=0.028 \\
p=0.799\end{array}$ & $\begin{array}{l}R=0.064 \\
p=0.556\end{array}$ & $\begin{array}{l}R=0.132 \\
p=0.220\end{array}$ & \begin{tabular}{l|}
$R=0.048$ \\
$p=0.660$
\end{tabular} & $\begin{array}{l}R=0.191 \\
p=0.075\end{array}$ & $\begin{array}{l}R=-0.157 \\
p=0.145\end{array}$ & $\begin{array}{l}R=0.091 \\
p=0.408\end{array}$ & $\begin{array}{l}R=0.153 \\
p=0.154\end{array}$ & $\begin{array}{l}R=-0.010 \\
p=0.930\end{array}$ & $\begin{array}{l}R=0.096 \\
p=0.583\end{array}$ \\
\hline Area & & & \begin{tabular}{|l|}
$R=0.961$ \\
$p<0.001$ \\
\end{tabular} & \begin{tabular}{l|}
$R=0.362$ \\
$p<0.001$ \\
\end{tabular} & $\begin{array}{l}R=0.450 \\
p<0.001\end{array}$ & $\begin{array}{l}R=-0.090 \\
p=0.402\end{array}$ & $\begin{array}{l}R=-0.363 \\
p=0.001\end{array}$ & $\begin{array}{l}R=0.072 \\
p=0.690\end{array}$ & $\begin{array}{l}R=0.495 \\
p<0.001\end{array}$ & $\begin{array}{l}R=0.345 \\
p<0.001\end{array}$ & $\begin{array}{l}R=-0.262 \\
p=0.129\end{array}$ \\
\hline $\begin{array}{c}\text { Dry } \\
\text { weight }\end{array}$ & & & & $\begin{array}{l}R=0.597 \\
p<0.001\end{array}$ & \begin{tabular}{|l|}
$R=0.641$ \\
$p<0.001$
\end{tabular} & $\begin{array}{l}R=0.051 \\
p=0.635\end{array}$ & $\begin{array}{l}R=-0.271 \\
p=0.011\end{array}$ & $\begin{array}{l}R=-0.124 \\
p=0.248\end{array}$ & $\begin{array}{l}R=0.450 \\
p<0.001\end{array}$ & \begin{tabular}{l|}
$R=0.389$ \\
$p<0.001$
\end{tabular} & $\begin{array}{l}R=0 . \\
p=0 .\end{array}$ \\
\hline LMA & & & & & \begin{tabular}{c|}
$R=0.880$ \\
$p<0.001$ \\
\end{tabular} & $\begin{array}{l}R=0.464 \\
R=0.401\end{array}$ & $\begin{array}{l}R=0.159 \\
p=0.139\end{array}$ & $\begin{array}{l}R=-0.019 \\
p=0.864\end{array}$ & $\begin{array}{l}R=0.072 \\
p=0.508\end{array}$ & $\begin{array}{l}R=0.282 \\
p=0.008\end{array}$ & $\begin{array}{l}R=-0.722 \\
p<0.001\end{array}$ \\
\hline LMAF & & & & & & $\begin{array}{l}R=0.006 \\
p=0.959\end{array}$ & $\begin{array}{l}R=0.157 \\
p<0.001\end{array}$ & $\begin{array}{l}R=-0.039 \\
p=0.720\end{array}$ & $\begin{array}{l}R=0.027 \\
p=0.800\end{array}$ & $\begin{array}{l}R=0.28 \\
p=0.007\end{array}$ & $\begin{array}{l}R=-0.568 \\
p<0.001\end{array}$ \\
\hline DF & & & & & & & $\begin{array}{l}R=0.047 \\
p=0,664\end{array}$ & $\begin{array}{l}R=0.026 \\
p=0.813\end{array}$ & $\begin{array}{l}R=0.091 \\
p=0.402\end{array}$ & $\begin{array}{l}R=0.093 \\
p=0.388\end{array}$ & $\begin{array}{l}R=-0.320 \\
p=0.061\end{array}$ \\
\hline L & & & & & & & & $\begin{array}{l}R=-0.693 \\
p<0.001\end{array}$ & $\begin{array}{l}R=-0.765 \\
p<0.001\end{array}$ & $\begin{array}{l}R=-0.002 \\
p=0.982\end{array}$ & $\begin{array}{l}R=-0.241 \\
p=0.162\end{array}$ \\
\hline $\mathbf{R}$ & & & & & & & & & $\begin{array}{l}R=0.702 \\
p<0.001\end{array}$ & $\begin{array}{l}R=-0.768 \\
p<0.001\end{array}$ & $\begin{array}{l}R=-0.111 \\
p=0.526\end{array}$ \\
\hline COM & & & & & & & & & & $\begin{array}{l}R=-0.063 \\
p=0.559\end{array}$ & $\begin{array}{l}R=0.119 \\
p=0.450\end{array}$ \\
\hline Iarea & & & & & & & & & & & $\begin{array}{l}R=0.062 \\
p=0.723\end{array}$ \\
\hline
\end{tabular}

TP $=$ Total leaf phenolics $\mathrm{TT}=$ Total leaf tannins 
Area $=$ Leaf area

LMA = Leaf mass area (dry weight)

LMAF = Leaf mass area (fresh weight)

DF = Leaf (dry/fresh) weight

$L=$ Leaf Length

$\mathrm{R}=$ Leaf Roundness

$\mathrm{COM}=$ Leaf Compactness

Per/Area $=$ Leaf $($ Perimeter $/$ Area $)$

$A_{\text {mass }}=$ Photosynthetic rate per unity of leaf mass 
Table S8. Association between species leaf traits and phylogeny (phylogenetic effects were estimated with the PHYSIG randomization procedure. Significant associations are highlighted in bold.

\begin{tabular}{|c|c|c|}
\hline Leaf Variable & $\mathrm{k}$ & $P$ \\
\hline \multicolumn{3}{|l|}{ Element content } \\
\hline $\log C(\%)$ & 0.145 & 0.26 \\
\hline $\mathrm{N}(\%)$ & 0.182 & 0.061 \\
\hline $\log \mathrm{Ca}(\%)$ & 0.202 & 0.020 \\
\hline $\mathrm{K}(\%)$ & 0.168 & 0.12 \\
\hline $\log M g(\%)$ & 0.120 & 0.48 \\
\hline $\log$ S (\%) & 0.119 & 0.40 \\
\hline $\mathrm{P}(\%)$ & 0.110 & 0.55 \\
\hline $\mathrm{Na}(\%)$ & 0.304 & 0.10 \\
\hline $\log \mathrm{Fe}\left(\mathrm{mg} \mathrm{kg}^{-1}\right)$ & 0.178 & 0.44 \\
\hline $\mathrm{Mn}\left(\mathrm{mg} \mathrm{kg}^{-1}\right)$ & 0.215 & 0.12 \\
\hline $\log V\left(\mathrm{mg} \mathrm{kg}^{-1}\right)$ & 0.245 & 0.36 \\
\hline $\log \mathrm{Cr}\left(\mathrm{mg} \mathrm{kg}^{-1}\right)$ & 0.220 & 0.072 \\
\hline $\log \mathrm{Ni}\left(\mathrm{mg} \mathrm{kg}^{-1}\right)$ & 0.195 & 0.25 \\
\hline $\log \mathrm{Cu}\left(\mathrm{mg} \mathrm{kg}^{-1}\right)$ & 0.128 & \\
\hline $\log \mathrm{Zn}\left(\mathrm{mg} \mathrm{kg}^{-1}\right)$ & 0.179 & \\
\hline $\log$ As $\left(\mathrm{mg} \mathrm{kg}^{-1}\right)$ & 0.2 & 0.44 \\
\hline $\log \mathrm{Sr}\left(\mathrm{mg} \mathrm{kg}^{-1}\right)$ & 0.090 & 0.95 \\
\hline Log Mo,mg kg ${ }^{-1}$ ) & 0.180 & 0.44 \\
\hline $\log \mathrm{Cd}\left(\mathrm{mg} \mathrm{kg}^{-1}\right)$ & 0.113 & 0.66 \\
\hline $\mathrm{Pb}\left(\mathrm{mg} \mathrm{kg}^{-1}\right)$ & & 0.14 \\
\hline \multicolumn{3}{|l|}{ Stoichiometry } \\
\hline $\mathrm{C}: \mathrm{N}$ & 0.189 & 0.087 \\
\hline P & 0.106 & 0.54 \\
\hline A & 0.150 & 0.16 \\
\hline g C & 0.137 & 0.26 \\
\hline $\mathrm{N}: \mathrm{K}$ & 0.106 & 0.67 \\
\hline Log P:K & 0.192 & 0.050 \\
\hline \multicolumn{3}{|l|}{ Carbon based Compounds } \\
\hline Log Total phenolics $\left(\mathrm{mg} \mathrm{g}^{-1}\right)$ & 0.172 & 0.28 \\
\hline Log Total tannins $\left(\mathrm{mg} \mathrm{g}^{-1}\right)$ & 0.106 & 0.57 \\
\hline \multicolumn{3}{|l|}{ Leaf morphological traits } \\
\hline Log leaf area $\left(\mathrm{m}^{-2}\right)$ & 0.205 & 0.045 \\
\hline Log leaf fresh weight $(\mathrm{g})$ & 0.199 & 0.024 \\
\hline Log leaf dry weight (g) & 0.203 & 0.020 \\
\hline Log LMA (g m²) (dry weight) & 0.425 & 0.009 \\
\hline Log LMA ( $\mathrm{g} \mathrm{m}^{-2}$ ) (fresh weight) & 0.513 & $<0.0001$ \\
\hline Leaf dry/fresh weight ratio & 0.170 & 0.16 \\
\hline
\end{tabular}




\begin{tabular}{|c|c|c|}
\hline Elongation & 7.388 & $<\mathbf{0 . 0 0 0 0 1}$ \\
\hline Roundness & 0.667 & $\mathbf{0 . 0 1 5}$ \\
\hline Compactness & 0.804 & $\mathbf{0 . 0 0 2}$ \\
\hline Leaf perimeter/leaf area & 0.238 & 0.067 \\
\hline Accumulated folivory (\%) & 0.104 & 0.894 \\
\hline
\end{tabular}


Table S9. Range of leaf elemental content of the 20 different elements analyzed in this study and in examples of previous studies in other tropical rainforests.

\begin{tabular}{|c|c|c|c|c|c|c|c|c|}
\hline Element & $\begin{array}{l}\text { Danum valley, } \\
\text { Borneo ( } 88 \mathrm{sp}) \\
\text { This study }\end{array}$ & $\begin{array}{l}\text { Oahu } \\
\left(\begin{array}{l}88 \mathrm{sp}) \\
\text { al. 2010a }\end{array}\right.\end{array}$ & $\begin{array}{l}\text { New South } \\
\text { Wales (12 } \\
\text { sp) Specht \& Turner } \\
2006\end{array}$ & $\begin{array}{l}\text { Taiwan (20 } \\
\text { sp) }\end{array}$ & $\begin{array}{l}\text { French Gaiana } \\
(45 \\
\text { sp) } \\
\text { al. } 2008\end{array}$ & $\begin{array}{l}\text { French } \\
\text { Guaiana (14 } \\
\text { sp) })^{\text {Coste et al. } 2005}\end{array}$ & $\begin{array}{l}\text { Quensland } \\
\text { (Australia) } \\
(162 \mathrm{sp})^{\text {Asner } e t} \\
\text { al.2009 }\end{array}$ & $\begin{array}{l}\text { Review of } \\
\text { different parts } \\
\text { of the world } \\
(150 \mathrm{sp})^{\text {Townsend }} \\
\text { et al. } 2007\end{array}$ \\
\hline N (\%) & $1.00-3.59$ & $0.74-3.44$ & $0.72-4.21$ & $0.12-3.8$ & $1.0-2.6$ & $2.5-1.1$ & $1.1-2.7$ & $1.83-1.92$ \\
\hline $\mathrm{Ca}(\%)$ & $0.23-5.33$ & $0.03-4.31$ & $0.24-2.74$ & 0.0 & $\nabla$ & & & \\
\hline K (\%) & $0.42-2.30$ & $0.30-2.62$ & $0.07-2.37$ & $0.20-5.4$ & & & & \\
\hline $\mathrm{P}(\%)$ & $0.04-0.16$ & $0.05-0.42$ & $0.04-0.51$ & $0.03-0.28$ & $0.04-0.12$ & & $0.06-0.22$ & $0.08-0.12$ \\
\hline $\mathrm{Na}(\%)$ & $<0.01-0.16$ & $0.03-1.65$ & & $\Rightarrow$ & & & & \\
\hline $\mathrm{Fe}\left(\mathrm{mg} \mathrm{kg}^{-1}\right)$ & $37-1266$ & $30-299$ & & $3.8-1010$ & & & & \\
\hline $\operatorname{Mn}\left(\mathrm{mg} \mathrm{kg}^{-1}\right)$ & $20-4335$ & \begin{tabular}{|l|}
$30-1676$ \\
\end{tabular} & & $22.6-4130$ & & & & \\
\hline $\mathrm{V}\left(\mathrm{mg} \mathrm{kg}^{-1}\right)$ & $0.2-4.6$ & \begin{tabular}{|l|}
$0.05-0.70$ \\
\end{tabular} & $M$ & & & & & \\
\hline $\mathrm{Cr}\left(\mathrm{mg} \mathrm{kg}^{-1}\right)$ & $0.2-21.0$ & \begin{tabular}{|l|}
$0.01-2.3$ \\
\end{tabular} & & & & & & \\
\hline $\mathrm{Ni}\left(\mathrm{mg} \mathrm{kg}^{-1}\right)$ & $1.1-70$ & $0.4-39$ & & & & & & \\
\hline $\operatorname{Mo}\left(\mathrm{mg} \mathrm{kg}^{-1}\right)$ & $<0.2-0.5$ & $0.01-2.4$ & & & & & & \\
\hline $\mathrm{Cd}\left(\mathrm{mg} \mathrm{kg}^{-1}\right)$ & $<0.1-0.4$ & $0.01-0.40$ & & & & & & \\
\hline $\mathrm{Pb}\left(\mathrm{mg} \mathrm{kg}^{-1}\right)$ & $0.20-2.35$ & $0.04-7.6$ & & & & & & \\
\hline
\end{tabular}




\section{References}

Asner GP, Martin RE, Ford AJ, Metcalfe DL, Liddell MJ. 2009. Leaf chemical and spectral diversity in Australian tropical forest. Ecological Applications 19:216-253.

Blomberg SP, Garland TJ, Ives AR. 2003. Testing for phylogenetic signal in comparative data: behavioral traits are more labile. Evolution 57:717-745.

Coste S, Roggy JC, Imbert P, Born C, Bonal D, Dreyer E. 2005. Leaf photosynthetic traits of 14 tropical rain forest species in relation to leaf nitrogen concentration and shade tolerance. Tree Physiology 25:1127-1137.

Garland TJ, Harvey PH, Ives AR. 1993. Procedures for the analysis of comparative data using phylogenetically independent contrast. Systems Biology 41:18-32.

Hättenschwiler S, Aeschlimann B, Coûteaux MM, Roy J, Bonal D. 2008. High variation in foliage and leaf litter chemistry among 45 tree species of a neotropical rainforest community. New Phytologist 179:165-175.

Lavin SR, Karasov WH, Ives AR, Middleton KM, Garland TJ. 2008. Morphometrics of the avian small intestine compared with that of nonflying mammals: A phylogenetic approach. Physiological and Biochemical Zoology 81:526-550.

Peñuelas J, Sardans J, Llusia J, Owen S, Carnicer J, Giambelluca TW, Rezende EL, Waite M, Niinemets Ü. 2010a. Faster returns on "leaf economics" and different biogeochemical niche in invasive compared with native plant species. Global Change Biology 16:2171-2185.

Peñuelas J, Sardans J, Llusia J, Owen S, Silva J, Niinemets Ü. 2010b. Higher allocation to low cost chemical defenses in invasive species of Hawaii. Jounal of Chemical Ecology 36:1255-1270. 
Specht A, Turner J. 2006. Foliar nutrient concentrations in mixed-species plantations of subtropical cabinet timber species and their potential as a management tool. Forest Ecology and Management 233:324-337.

Townsend AR, Cleveland CC, Asner GP, Bustamante MMC. 2007. Controls over foliar $\mathrm{N}: \mathrm{P}$ ratios in tropical rainforest. Ecology 88:107-118.

Webb CO, Donoghue MJ. 2005. Phylomatic: tree assembly for applied phylogenetics. Molecular Ecology Notes 5:181-183.

Wu CC, Tsui CC, Hseih CF, Asio VC, Chen ZS. 2007. Mineral nutrient status of tree species in relation to environmental factors in the subtropical rain forest of Taiwan. Forest Ecology and Management 239:81-91. 